\title{
Archaeological Investigations of a Shell Midden (41HR39) at De Zavala Point, Harris County, Texas
}

Anna J. Taylor

Follow this and additional works at: https://scholarworks.sfasu.edu/ita

Part of the American Material Culture Commons, Archaeological Anthropology Commons, Environmental Studies Commons, Other American Studies Commons, Other Arts and Humanities Commons, Other History of Art, Architecture, and Archaeology Commons, and the United States History Commons

Tell us how this article helped you.

This Article is brought to you for free and open access by the Center for Regional Heritage Research at SFA ScholarWorks. It has been accepted for inclusion in Index of Texas Archaeology: Open Access Gray Literature from the Lone Star State by an authorized editor of SFA ScholarWorks. For more information, please contact cdsscholarworks@sfasu.edu. 


\section{Archaeological Investigations of a Shell Midden (41HR39) at De Zavala Point, Harris County, Texas}

\section{Creative Commons License}

\section{(c) (1) \&}

This work is licensed under a Creative Commons Attribution-NonCommercial 4.0 International License 


\title{
ARCHAEOLOGICAL INVESTIGATIONS \\ OF A SHELL MIDDEN [41 HR 39] \\ AT DE ZAVALA POINT, HARRIS COUNTY, TEXAS
}

\author{
Anna J. Taylor \\ With Contributions By \\ Robert F. Scott IV, Anne A. Fox, and Joseph H. Labadie \\ Department of the Army, Galveston District, \\ Corps of Engineers Contract Number DACW64-85-M-0199
}

Center for Archaeological Research

The University of Texas at San Antonio

Archaeological Survey Report, No.150

1985 

ARCHAEOLOGICAL INVESTIGATIONS

OF A SHELL MIDDEN (4I HR 39)

AT DE ZAVALA POINT, HARRIS COUNTY, TEXAS

Anna J. Taylor

With contributions by

Robert F. Scott IV, Anne A. Fox, and Joseph H. Labadie

Project Performed for the

Department of the Army, Galveston District, Corps of Engineers Under Contract No. DACW64-85-M-0199

For Consideration of the 01d River Fleet and Shipyard

Department of the Army Permit Application No. 17151

Principal Investigator

Dr. Thomas R. Hester

Center for Archaeological Research

The University of Texas at San Antonio ${ }^{\circledR}$

Archaeological Survey Report, No. 150 

Archaeological investigations at site 41 HR 39 on De Zavala Point in Channelview, Harris County, Texas, were conducted by personnel from the Center for Archaeological Research, The University of Texas at San Antonio from December 16 through December 22, 1984. The site is recorded as an aboriginal shell midden with a historic component which will be impacted by the proposed disposal of dredged materials under the Department of the Army Permit App 7 ication No. 17151 , during industrial development of the area. The field investigations were conducted for the Department of the Army, Galveston District, Corps of Engineers, to determine the eligibility of the site for recommendation for nomination to the National Register of Historic Places.

Field work at site 41 HR 39 involved excavating nine shovel tests, two $1-\mathrm{m}^{2}$ controlled test units, five backhoe test pits, and five backhoe trenches, mapping and photographing the site, and gathering artifacts exposed by wave action along the bluff which marks the northern and eastern limits of the site. Analysis of the site stratigraphy and cultural materials indicates that the site contains a stratum of Rangia cuneata she 11 with prehistoric and historic materials in a dark, sandy clay loam matrix. The shell midden stratum overlies a sterile clay matrix. Most, if not al1, of the site appears to have been disturbed by bioturbation, erosion, historic dredging, and other historic occupation and utilization of the site area.

The research potential of the remaining historic component and the aborigina she 11 stratum at 41 HR 39 appears to be low. The site is therefore recommended to be not eligible for nomination to the National Register of Historic P1aces. 
ABSTRACT . . . . . . . . . . . . . . . . . . . . LIST OF FIGURES . . . . . . . . . . . . . . . . . . . . . . LIST OF TABLES . . . . . . . . . . . . . . . . . . . . . ACKNOWLEDGMENTS . . . . . . . . . . . . . . . . . . . . . INTRODUCTION . . . . . . . . . . . . . . . . . . . . . . . ENVIRONMENTAL SETTING . . . . . . . . . . . . . . . . . . Geology

Soils.

Flora and Fauna

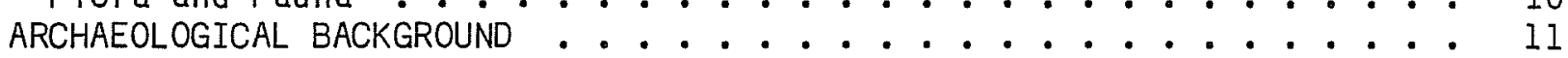

Prehistoric Period . . . . . . . . . . . . . . . . . . 11

Historic Period . . . . . . . . . . . . . . . . 12

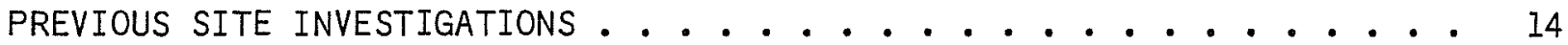
RESEARCH GOALS AND METHODS . . . . . . . . . . . . . . . . . . 16 SITE DESCRIPTION . . . . . . . . . . . . . . . . . . . 17 THE EXCAVATIONS ....................... . 19



Prehistoric Materials . . . . . . . . . . . . . . 30

Ceramics......................... 31

Lithics ........................ . . 37



Fine Screen Sample... . . . . . . . . . . . . . 51

Historic Materials ...................... 53

Ceramics....................... 53

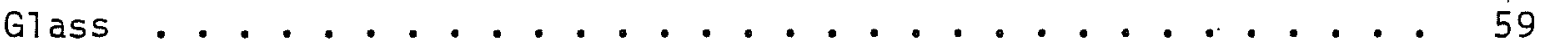

Metal ......................... 63

Other Historic Materials . . . . . . . . . . . . . 65

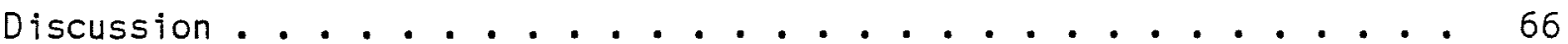

SUMMARY AND RECOMMENDATIONS . . . . . . . . . . . . . . . . 66

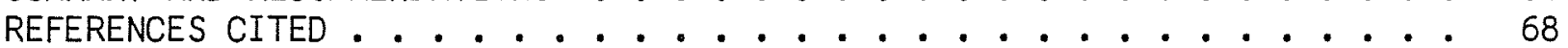




\section{LIST OF FIGURES}

1. Project Location Map .................... . 2

2. Contour Map of Project Area . . . . . . . . . . . . . 3

3. Map of Excavations ................. 4

4. General Views of Site 41 HR 39 .............. . 7

5. Views of the North Bluff and Shoreline of the Site . . . . . . 8

6. Backhoe Trench 1, North Profile ................. 21

7. Backhoe Trench 2, East Profile ... . . . . . . . . . . . 22

8. Backhoe Trench 3, North Profile... . . . . . . . . . 25

9. Backhoe Trench 4, South Profile... . . . . . . . . . 27

10. Backhoe Trench 5, West Profile ............ 29

11. Aboriginal Ceramics from Site 41 HR $39 . . . . . . . . . .33$

12. Aboriginal Ceramics from Site 41 HR 39 ........... 34

13. Aboriginal Ceramics from Site 41 HR $39 . . . . . . . . .35$

14. Lithic Artifacts from Site 41 HR $39 . . . . . . . . . . .3939$

15. Lithic Artifacts from Site 41 HR $39 . . . . . . . . . .440$

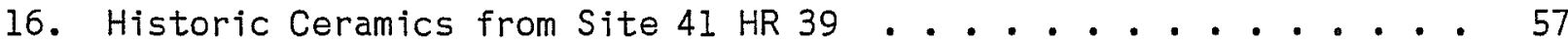

17. Glass and Metal Artifacts from Site 41 HR 39 ........ 61

\section{LIST OF TABLES}

1. Shovel Test Descriptions ... . . . . . . . . . . . 20

2. Provenience of Aboriginal Ceramics ............. 32

3. Provenience of Lithic Materials . . . . . . . . . . . . 38

4. Quantification of Rangia cuneata Shel1s ............ 43

5. Quantification of Non-Rangia cuneata Shel1s . . . . . . . . 44

6. Rangia cuneata Growth Stage Evaluations . . . . . . . . . . . . . 45

7. Comparison of Observed and Expected Rangia cuneata Growth Stage Proportions .................. . . 45

8. Quantification of Vertebrate Faunal Remains . . . . . . . . . 46

9. Quantification of Fine Screen Samples by Weight . . . . . . . 52

10. Provenience of Historic Materials: General Categories . . . . 54

11. Provenience of Historic Ceramics: Earthenware . . . . . . . 56

12. Provenience of Historic Ceramics: Stoneware . . . . . . . . 58

13. Provenience of Historic Ceramics: Porcelain . . . . . . . . . 60

14. Provenience of Glass . . . . . . . . . . . . . . 62

15. Provenience of Metal Artifacts .............. 64 


\section{ACKNOWLEDGMENTS}

Several individuals contributed to the De Zavala project. Jan Stokes, staff archaeologist for the Department of the Army, Galveston District, Corps of Engineers (COE) provided advice and background information about 41 HR 39 and the vicinity. Also, Jan Stokes, Carolyn Good, and Gail Celmer, staff archaeologists for the Galveston District, COE, served as volunteer crew members during part of the test excavations. Donna Deaton of San Antonio also was a volunteer crew member.

James Bradley and Jack R. Lillard of Channelview, employees of the 01d River Fleet and Shipyard, provided the archaeologists with information about the site and donated their private collections of artifacts from the site to the Center for Archaeological Research. The University of Texas at San Antonio (CAR-UTSA), for curation.

The field crew consisted of A. J. Taylor (field director) and Joe Labadie and George Deaton (archaeological field crew members) of the CAR-UTSA. Both Deaton and Labadie contributed their experience and enthusiasm to the project. Cathy Dodt processed the materials in the 1 aboratory at the CARUTSA and a1so recorded the necessary data for the Rangia cuneata seasonal ity study. Joe Labadie examined, recorded, and described the prehistoric ceramics. Anne Fox of the CAR-UTSA identified and provided information concerning the historic ceramics and glass, and some of the metal items. Robert F. Scott IV of A7to, Texas, analyzed the vertebrate faunal materials. Kenneth Brown of the CAR-UTSA contributed advice about the 1 ithic analysis. Jan Stokes and Carolyn Good of the COE contributed information concerning soil formation in the project area. David Hafernik, Stephen Black, Fred Oglesby, and George Deaton drafted the maps and profiles for this report. The 1 ithic and ceramic artifacts were $i 11$ ustrated by Margaret Greco. Sharon Quirk and Ann Young of the CAR-UTSA both provided much assistance and support, during their editing and preparation of the report. Mary Lou ET 1 is of the CAR-UTSA took care of the many matters necessary for the operation of the project.

Dr. Thomas R. Hester (principal investigator), Director, and Jack D. Eaton (co-principal investigator), Associate Director, of the CAR-UTSA, provided supervision, support, and encouragement throughout the project. 


\section{INTRODUCTION}

Archaeological investigations were conducted at site 41 HR 39 on De Zavala Point (Fig. 1) by personnel from the Center for Archaeological Research, The University of Texas at San Antonio (CAR-UTSA) for the Department of the Army, Galveston District, Corps of Engineers (COE). The site is located within the community of Channelview, in eastern Harris County, Texas, at the confluence of the 01d River and Buffalo Bayou (Figs. 2-5). The site consisted of a Rangia cuneata shel1 midden with a historic component.

The Galveston District, COE is processing Department of the Army Permit Application No. 17151, 01d River Fleet and Shipyard, Applicant, to dredge a $30.5 \mathrm{~m} \times 84.0 \mathrm{~m}$ area in the $01 \mathrm{~d}$ River (an abandoned channel of the San Jacinto River) and dispose of the material on De Zavala Point, which will include the site 41 HR 39 locality (Stokes 1984:attachment A). Dredged material wi11 be placed behind an existing 1-m high bulkhead on the north shore and on the northeast corner of De Zavala Point (Figs. 4,a; 5,b). The authority for the permit is detailed in Section 10 of the River and Harbour Act of 1899, and in Section 404 of the Clean Water Act of 1977 . The authority for the archaeological investigations is detailed in Section 106 of the National Historic Preservation Act, as amended, and the 36CFR 800 implementing regulations for the National Historic Preservation Act.

The purpose of the study was to assess the eligibility of site 41 HR 39 for nomination to the National Register of Historic Places, as specified in the Scope of Work (Department of the Army, Galveston District, Corps of Engineers). The archaeological investigations consisted of the excavation of nine shovel tests, two $1-\mathrm{m}^{2}$ controlled test units, five backhoe test pits, and five backhoe trenches at the site.

\section{ENVIRONMENTAL SETTING}

Site 41 HR 39 is on top of a 6.1-m high bluff of De Zavala Point, overlooking the 01d River to the north. The point of 1 and upon which the site is situated is at the confluence of the 01d River and Buffalo Bayou (Fig. 1 ).

\section{GEOLOGY}

The Quaternary geologic period coastal terraces of the Texas coastal plain predominantly consist of a series of off-lapping terraces parallel to the coast, which were deposited during interglacial stages and were formed by a 11 uvial and deltaic sedimentation. The most recently formed coastal terrace is the Beaumont Formation, which is by the Gulf and is from 30,000 to 37,000 years 01d. Evidence of ancient and recent sedimentary depositional environments can currently be seen in the general Galveston and Houston, Texas, vicinity. During the Pleistocene geologic epoch the Trinity, San Jacinto, Brazos, and Colorado Rivers transported suspended mud and bottom-load sand which were deposited in Gulf Coast deltaic areas. Within these areas were meander belt loops which deposited sandy point bars and formed natural levees; mud and silt deposited during periodic flooding created floodplains and sandy crevasse splays. Between ca. 12,000 and 3500 B.P., a rise in the 
This page has been

redacted because it

contains restricted

information. 
This page has been

redacted because it

contains restricted

information. 
This page has been

redacted because it

contains restricted

information. 
sea level resulted in a marked northward regression of the coast 1 ine and in the initial development of the Galveston Bay estuary. Stream hydrology changed from conditions of high discharge and lateral erosion to that of $10 \mathrm{w}$ discharge and stream incision from ca. 12,000 B.P. to 5000 B.P., and by ca. 3500 B.P., it had changed to moderate discharge and floodplain aggradation. The part of the Beaumont Formation with in the general study area was probably deposited by the Beaumont-age (1 ate Pleistocene epoch) Brazos River. Sediments resembling Beaumont Formation deposits, which have a predominantly silt loam surface horizon overlying reddish brown and yellowish brown clays, silty clays, and clay loams, are present in Harris County at depths of $3.05 \mathrm{~m}$ to $4.57 \mathrm{~m}$. Elevations in Harris County range from sea leve1 to $38.1 \mathrm{~m}$. Within the study area elevations range from $0 \mathrm{~m}$ to $6.1 \mathrm{~m}$ above mean sea leve1 (Bernard et a1. 1970:Fig. 44; Fisher et a1. 1972:Fig. 4; Bureau of Economic Geology 1982; Day 1982; Aronow 1982, citing Bernard and LeB 1 anc 1965:Fig. 5, and $V$ an Siclen and Harlan 1965:Plate 1; Aten 1983a:104-139; Aronow 1984:2; Fields and Jackson 1984:1).

The Galveston and Houston vicinity is currently affected by subsidence and erosion, and these conditions are clearly evident at De Zavala Point. Local residents have estimated that from $2.7 \mathrm{~m}$ to $3.0 \mathrm{~m}$ of subsidence has occurred within the general project area during the 1 ast 20 years (Day 1982). Results of a study by Gabryish and Bonnet (1977), however, indicate that a 1 esser amount of subsidence--approximately 1.98 m--has occurred during the previous 75 years, with most of it occurring during the 1 ast 40 years. Day (1982) notes that comparison of a 1982 topographic map of the study area prepared by Espey, Huston \& Associates with a 1967 USGS $7.5^{\prime}$ topographic map shows that an estimated $100 \mathrm{~m}$ of 1 and surface along the shoreline of De Zavala Point has become submerged within the 1 ast 15 years (ibid.). At the San Jacinto Battlefield south of the project area, the 1 and was found to have subsided a total of $1.8 \mathrm{~m}$ from 1898 to 1967 . One probable cause of the area subsidence and also of the shoreline erosion is the withdrawal of oil field fluids and groundwater, which is centered around the community of Baytown, east of De Zavala Point. Wave erosion has also increased due to traffic on the waterways of the area (Cartier and Hole 1972:90; McGuff and Ford 1974:23; Aronow 1982, 1984:1; Fields and Jackson 1984:3).

Dredging operations in the Houston Ship Channel in the vicinity of De Zavala Point have also affected the rate of subsidence and erosion. The Buffalo Bayou Ship Channel Company was formed in 1869 to develop what became known as the Houston-Galveston Ship Channel for use by deep draft ships. Since that time the depth of dredging in the Houston Ship Channel has increased from $2.7 \mathrm{~m}$ in 1874, to $12.2 \mathrm{~m}$ in 1957 (Day 1982; Alperin 1983), an increase in depth of $452 \%$. As a result of the enlargement of the channel the number and size of ships using the channel have increased, with an accompanying increase in wave action and erosion. At 1 east $0.6 \mathrm{~m}$ of dredged material has been spread on portions of De Zavala Point as a result of dredging activities (Aronow 1982, citing Fisher et a 1. 1972; Voe11inger 1982). Aronow (1982) examined the soils at De Zavala Point, however, and concluded that the identification of the soils at De Zavala Point as disturbed materials was 1argely erroneous. 
Figure 4. General Views of Site 41 HR 39.

a, view facing north-northwest from the top of the Falcon Cement Inc., storage towers, toward the north and east shorelines of the project area. A backhoe (backhoe trench 5) is visible in the central part of the photograph, and the pile of dredged material is to the right of the bulkhead along the north shore in the upper left part of the photograph;

b, view of eroded she 11 in the southwestern part of the project area, looking towaro the east shoreline. 






a

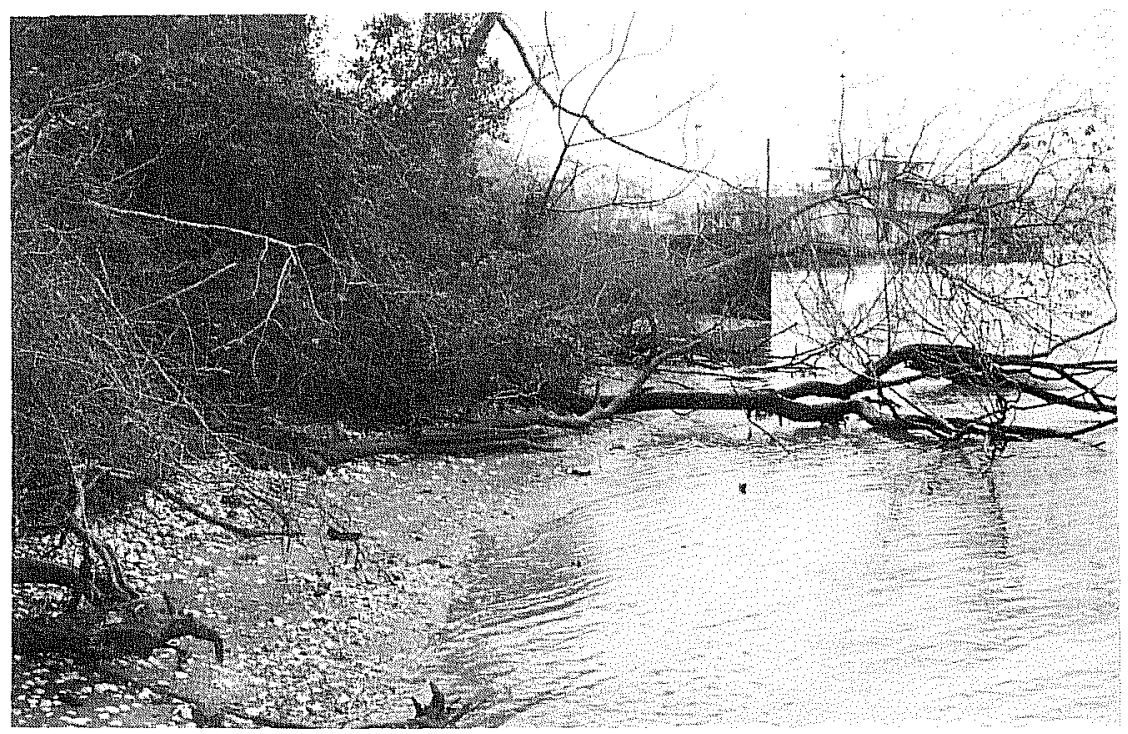

b

Figure 5. Views of the North Bluff and Shoreline of the Site. a, view facing south of the eroding north bluff and shoreline at low tide, near the bulkhead; b, view facing west of the north shoreline at 1 ow tide, and the nearby bulkhead and tugboat area. 


\section{SOILS}

Soils in the project area are of the Aldine series, and are dark gray brown, acidic, fine sandy loams which overlie a stratum of gray clay. These soils are typical of the dark-colored, crumbly, 1 imelike clays of the Gulf Coast Prairie, within which the study area is located. Aldine soils parallel and flank the floodplain of the San Jacinto River and several other streams of Harris County. The profile of soils within the Aldine series is generalized as having a sandy, 1 ight-colored horizon that varies in thickness from roughly $10.8 \mathrm{~cm}$ to $15.24 \mathrm{~cm}$. The B and A horizon has fingers or "tongues" of a horizon material which moved down along cracks, and a $B$ horizon of clay, clay loam, or silty clay which extends to depths of over $1.52 \mathrm{~m}$ (Pool 1975:68; USDA 1976; Aronow 1982, citing Wheeler 1976).

As noted by Aronow (1982), the general profile descriptions do not mention any calcareous materials or reddish yellow or reddish brown colors, though both were found in several test pits in Aldine-like profiles in the southern part of De Zavala Point investigated by Day (1982), adjoining the present study area. In the excavation areas opened by Day (1982), and as interpreted by Aronow (1982), there was what appeared to be a preserved part of a natural surface. Exposed along the north bank of De Zavala Point, at site 41 HR 39, were sediments overlain by what appeared to be an undisturbed she 11 midden (cf. Fig. 4,a,b). Along the southern shore of the Point, recent shel1 fil1 varying from $20.32 \mathrm{~cm}$ to $61 \mathrm{~cm}$ in thickness covered wel1-defined soil profiles which overlaid abundantly calcareous materials. In adjacent areas there was a transition from reddish clay, which probably originated from a flood basin or backswamp, to fairly clean reddish very fine to fine fluvial sand, which seemed to be consistent with the fluvial origin of the Pleistocene material. Aronow (1982), a regional expert on soil deposition, concluded that although the surface of De Zavala Point has been considerably modified, the bulk of the materials appear to be natural and in place, rather than being dredged material.

Aronow (1982) suggested some possible origins for the soils found along the San Jacinto River, particularly at De Zavala Point. Much of the sandy A horizon soils may be windblown material derived from sandy stream terraces of Deweyville age which are now submerged. Alternatively, part of the region, especially at the site, may be a Deweyville-age San Jacinto erosional terrace which was cut into the surface of the local Beaumont-age Brazos River sediments, thus reducing the vertical distance to calcareous materials and reddish sediments. In this instance the sandy surface of the Aldine soils would be the thin fluvial residuum which is now wind modified and left on the surface of the strath. "The scarp between the upper and 10 wer levels then would be an erosional feature left during this episode of terrace formation" (ibid.). Yet another possibility was that the surface may have been cut by exceptional prehistoric hurricane storm surges which occurred during a period distant enough to allow the development of the mature Aldine-like profile (Aronow 1982). 


\section{CLIMATE}

The average annual rainfal1 in Harris County is $122 \mathrm{~cm}$. This county is within the Upper Coast Division of the region of summer maximum rainfa 11 . The modern climate is mild with an annual mean temperature of $21.1^{\circ} \mathrm{C}\left(70^{\circ} \mathrm{F}\right.$; Carr 1967:4; Webb Vo1. 1 1952:777). According to Aten (1983a:104-139), however, before 8500 B.P. (years Before Present), the climate was cool and moist but with less variation, or seasonality, than occurs currently. From 8500 B.P. to 5000 B.P., the regional climate was warmer and drier than it is today. Since 4000 B.P. or 3000 B.P., the climate has been predominantly modern.

\section{FLORA AND FAUNA}

The natural region within which site 41 HR 39 is 1 ocated is the Coastal Prairie and Marsh zone, a part of the West Gulf Coastal Plains bordering the tidewater. The northern part of Harris County, however, is in the Pine Woods region (Fenneman 1938; Arbingast et a1. 1973; Pool 1975:4-6).

Three main vegetation habitats are within the general study area: second growth woodland, grassland, and new growth in recently disturbed areas. The dominant species within the second growth woodland, which included De Zavala Point prior to recent development, are Texas sugarberry (Celtis 1 aevagata), American elm (Ulmus americana), black willow (Salix nigra), a stand of loblolly pines (Pinus taeda), river birch (Betula nigra), and yaupon (I 1 ex vomitoria). The woodlands understory includes predominantly Japanese honeysuckle (Lonicera japonica), with a 1 imited amount of poison ivy (Rhus toxicodendron) and Virginia creeper (Parthenocissus quinquefolia). Within the grasslands the major species are Bermuda grass (Cynodon dactylon), ticktree foil (Desmondium sp.), threeawn (Aristida sp.), ragweed (Ahbrosia sp.), and a few McCarthy rose bushes (Rosa bracteata). In the recentiy disturbed areas, which includes all of the project area, the dominant species are pokeweed (Phytolocca americana), poison ivy (Rhus toxicodendron), Texas sugarberry seed lings (Celtis laevagata), blackberry (Oxalis priceae), ironweed (Vernonia sp.), and yellowwood sorrel (0xal is priceae) (Voel1 inger 1982:1).

Archaeological sites in the region have yielded faunal assemblages which show a major reliance upon aquatic and fluvial woodland species. The major faunal types are the brackish water clam (Rangia cuneata and R. flexuosa), oyster (Crassostrea virginica), catfish (Ictalurus spp.), black drum (Pogonias cromis), freshwater drum (Aplodinotus grunniens), gar (Lepisosteus spp.), sheepshead (Archosargus cephaloprobatus), al1 igator (A11 igator mississippiensis), various turtles, various waterfow 1 , bison (Bison bison), white-tailed deer (Odocoileus virginianus), black bear (Ursus americanus), rabbits (Sylvilagus floridanus and S. aquaticus), opossum (Didelphis marsupialis), raccoon (Procyon lotor), muskrat (Ondatra zibethica), mink (Mustela vison), and skunk (Mephitis mephitis) (Fields and Jackson 1984:3, citing Gilmore 1974:22, 28-29, Di7lehay 1975:166-178, and Mercado-A 11 inger et a 1 . $1984: 42-48$ ). 
ARCHAEOLOGICAL BACKGROUND

\section{PREHISTORIC PERIOD}

The prehistoric cultural sequence of the Galveston Bay area was most recentiy investigated and described by Aten (1979, 1983a). The sequence proposed by Aten (ibid.) is divided into two major parts, the Preceramic period and the Ceramic period.

Little is known about the Preceramic period (ca. 12,000 to 2000 B.P.) due to a scarcity of sites which date to that period. Many Preceramic sites were destroyed by early Holocene valley scouring, or are buried beneath stream floodplains or beneath the Gulf of Mexico. It is hypothesized that social organization remained much the same throughout the period, with individuals, family groups, task groups, and small bands serving as the primary social units. The technology remained generalized, being suited to the utilization of a wide array of resources. Recorded site densities and environmental reconstructions suggest that during the early Holocene the population size increased, then it dramatically decreased in the middle Holocene, and then during the late Holocene it again increased. Settlement strategies possibly changed from a pattern of infrequently occupied and scattered sites to sites which occur predominantly on inland stream floodplains and estuaries (Aten 1983a: $160-162$ ).

The Ceramic period (ca. 2000 to 200 B.P.) is subdivided into six subperiods: Clear Lake (A.D. 100 to 425), Mayes Is 1 and (A.D. 425 to 650), Turt le Bay (A.D. 650 to 1000), Round Lake (A.D. 1000 to 1350), 01 d River (A.D. 1350 to 1725), and Orcoquisac (A.D. 1725 to 1810; Aten 1983a:285). The sequence, and descriptions, of ceramics which occur during these subperiods are described in detail by Aten (1983a). The general order of appearance of the various types of ceramics is as briefly follows. Sandy paste Goose Creek wares and various Tchefuncte types first appear at Ca. A.D. 100 during the Clear Lake subperiod. Goose Creek ceramics continued to occur during the Mayes Is 1 and and Turtle Bay subperiods. During the last of the Round Lake subperiod, Goose Creek ceramics and a 1 so grog-tempered Baytown and San Jacinto wares occur. There is an increased occurrence of Goose Creek wares and the consistent appearance of bone-tempered ceramics during the $01 \mathrm{~d}$ River subperiod. During the Orcoquisac subperiod, there are Goose Creek wares with sma 11 percentages of grog-tempered and bone-tempered ceramics (ibid.).

Aten's (1983a) classification of prehistoric ceramics from the upper Texas coast is 1 argely based upon paste categories: sandy paste, sand-tempered paste, and grog-tempered paste. The term temper indicates the presence of an aplastic material which was added to the pottery clay. Grog designates the use of fired clay or finely crushed sherds as a pottery temper. Temper, decoration, and paste texture are also major factors in the classification of coastal ceramics (ibid.:209-221, also see footnote on pages 212-213, citing Shepard 1963:25).

Along the upper Texas coast, chert, quartzite, and silicified wood pebbles and cobbles were utilized from the inland Willis Formation or from the terraces along the Trinity or San Jacinto Rivers. Bipolar flaking and handheld direct percussion techniques of 1 ithic reduction were both used. Dart 
points occur into the Mayes Island subperiod, when the bow and arrow was introduced. During the Mayes Island period, the amount of $f 1$ akes recovered from sites decreases; the density of flakes slowly increases during the $01 d$ River period, and then rapidly decreases during the Orcoquisac period. The use of silicified wood and quartzite increases with the introduction of arrow points, though it declines by the Historic period. Other 1 ithic tools include expanded base perforators, sma 11 expanded base dri $11 \mathrm{~s}$, bipointed drills, flat base dril1s, microflints, general ovoid bifaces, ovoid end scrapers, elongate end scrapers, uniface side scrapers, end scrapers, ovoid end scrapers, round uniface and/or biface tools, and general utilized flakes. Sandstone fragments used for grinding or abrading, and also pumice and mudstone abraders are found on coastal sites, as are unworked fragments of imported slate, quartz cobbles, ocher, and asphalt (Aten 1983a:246-262, 266$267,300-304$ ).

Bone tools found on upper coastal sites are items such as gorges, projectile points, and socketed blunt points (which occur from the 1 ate Preceramic through the early Turtle Bay period), spatulas, incised fragments, ant 1 er tine flaking tools, and ulna tools. Artifacts made of shel1 are oyster shell cutting implements, Busycon fragments, and a perforated Rangia valve. A fragment of a pointed wooden stake, and impressions of cordage and netting have also been recovered (Aten 1983a:262-266, 302).

\section{HISTORIC PERIOD}

Before European involvement around Galveston Bay, the area was occupied by the Akokisa (Aten 1983a:29-37). Prior to 1821, European involvement in the Galveston Bay area consisted of early explorations, beginning with the Alonso Alvarez de Pineda expedition of 1519, and including the travels of Alvar Nuñez Cabeza de Vaca, a member of the failed Panfilo de Narvaez expedition of 1527-1528; trading by the French; efforts by the Spanish to prevent French activities in the area; and smuggling and privateering by individuals such as Jean and Pierre Lafitte and Luis Michel Aury from ca. 1816 to 1820. In 1821 , Stephen F. Austin received a grant of 1 and from Mexico, and then AngloAmericans began to settle in the general Galveston Bay vicinity (Bolton 1962; Webb Vol. I 1952:78-79, 81-84, 261-263; Webb Vo1. 2 1952:5-6; Fie1ds and Jackson $1984: 7$ ).

In 1822, approximately 15 or 20 families of European descent moved to an area along the San Jacinto River, two or three miles above the present community of Highlands. This group was soon joined by others who came from the United States, and one, a Mrs. Jane Long, from Bolivar Point in eastern Galveston County. Thirty-two people received land along the San Jacinto River, Buffalo Bayou, and Cedar Bayou from the government of Mexico in 1824. Boats were operated regularly on Buffalo Bayou by 1824. Harrisburg, the first town in the area, was establ ished on the south bank of Buffalo Bayou before 1825 . Harrisburg served as the seat of government for the Repub 1 ic of Texas during March and Apri1 of 1836, but it was burned by the Mexican army prior to the Battle of San Jacinto, which occurred on Apri1 21, 1836. The seat of the Texas government was then moved to Houston where it remained until Austin was made the state capital in 1839 (Looscan 1914:201; Webb Vol. 1 1952:777-778, 848; Webb Vo1. 2 1952:554). 
Manue 1 Lorenzo Justiano de Zavala was issued a bond on August 12, 1835, for a 1 abor (approximately 176 acres or 71 hectares) of 1 and on De Zavala Point, and moved his family to a house (site 41 HR 32) on or near De Zavala Point in 1835. This property was part of a league of 1 and granted to Wi11 iam Harris and David Carpenter on August 6, 1824. The house had been built by Philip Singleton in 1828 or 1829. De Zavala was born in Yucatan, Mexico, in 1789. He was elected governor of the State of Mexico in 1827 and again in 1832, and also served in various other political offices, and was a proponent of democratic reform in Mexico. He moved to Texas when he decided that Santa Anna, the president of Mexico, was not going to observe the Constitution of 1824. De Zavala then became active in Texas politics. In 1836, he was a signer of the Declaration of Independence at Washington-on-the-Brazos, and was also elected ad interim vice president of Texas. De Zavala resigned from office in October 1836, and died less than one month 1ater (Looscan 1914:198; Webb Vo1. I 1952:498; Brandimarte 1982; Voe1 1 inger 1982:3; Harris County Deed Records Vol. E:159-160). He was buried in the De Zavala family cemetery, roughly $300 \mathrm{~m}$ southwest of the project area (Fox 1982).

In the 1 ate 1800 s or early 1900s, Tom Copings built a house at or near the De Zavala homestead location, on the south end of De Zavala Point, facing the confluence of Buffalo Bayou and a meander of the San Jacinto River (which is now known as the 01d River). By 1915, there were at least 10 structures located on De Zavala Point. During the 1920s, a ferry was built across Buffalo Bayou from De Zavala Point, which was then known as Copings Point, to San Jacinto. It was during the 1920 s that De Zavala Point also became known as Muggers Point after a bootlegging operation was established there. Brick used to construct structures on De Zavala Point from 1870-1920s may have been obtained from nearby Cedar Bayou, which had from six to eleven brickyards in operation to supply the general Galveston Bay area during this period (Cartier and Hole 1972:61; Voel1inger 1982:4, citing Fossen 1982, Sumpter 1982, and $W i 11 i a m s$ 1982). The last private citizen to own and uti 1 ize De Zavala Point was Mr. Askew. He cleared the property of existing vegetation and structures and built a two-story, six-room ranch house and stables (Voellinger 1982:4, citing Fossen 1982, Sumpter 1982, and Wil1iams 1982).

The United States Government bought De Zavala Point and adjoining property in 1937 to build the San Jacinto Naval Ordnance Depot. With the exception of the Askew home, which was used for officer housing, al 1 existing structures were removed. Six rectangular structures, possibly barracks, were built along the center of De Zavala Point. A possible pumphouse and 1 aundry were built west of the barracks; one structure was along the bank of the $01 d$ River northwest of the 1 aundry; and another structure, which may have been the officers quarters or Askew house, was on the southern shore of the Point. Along the bank of the 01d River, a course of shel1 roads was 1 aid which also encircled the six barracks and led to each of the other structures. The San Jacinto Ordnance Depot (41 HR 423) was abandoned and the buildings dismantled soon after World War II ended, and the property was sold to the Mil1 ray Corporation of Houston in 1964. Second growth vegetation was then al lowed to grow on the site, and the area was used as a dump by $10 c a 1$ residents (Voel1inger 1982:4-5, citing U.S. Air Force aerial photograph, flight date 5 May 1953, Harris County Deed Records Vo1. 5735:605, Vo1. 998:298, and Steere 1982). 


\section{PREVIOUS SITE INVESTIGATIONS}

Site 41 HR 39 was originally recorded in 1956 during an extensive survey of an approximately five-mile radius of Lynchburg, Texas, by W. B. Neyl and and R. B. Worthington, avocational archaeologists. During an archaeological survey of the Lost Lake Disposal Area in 1973 by the Texas Archeological Survey (McGuff and Ford 1974:16, Fig. 4, A; Balcones Research Center, Texas Archeological Research Laboratory site files), site 41 HR 39 was observed from a distance and reported to be wel 1 preserved by professional archaeologists.

Fox (1982) did a survey and archival research of the Lorenzo de Zavala family cemetery, which is roughly $300 \mathrm{~m}$ southwest of the present project area, and the immediate area on the south slope of De Zavala Point. This study was done for a feasibility report for the TERA Corporation of Dallas, Texas, who were planning the construction of a docking facility in this area. The De Zavala family cemetery was found to be partially submerged, and no additional sites were found in the project area. The decision was made to not develop the cemetery area, but rather to fence off and protect the cemetery, and work around it.

During 1982, historic research and archaeological survey and testing were conducted on the southern part of De Zavala Point by personnel of Espey, Huston \& Associates (Voe11 inger 1982; Brandimarte 1982; Day 1982). This work was done in conjuction with the Department of the Army Permit App 1 ication No. 16000 for the construction of a cement terminal and access road by Falcon Cement, Inc. Brandimarte (1982) conducted archival research as part of these investigations, attempting to find the probable location of the original Lorenzo de Zavala homesite (4I HR 32), and of structures relating to the subsequent historic occupation of De Zavala Point.

Three Rangia shel1 middens in addition to the study site (4I HR 39) have been located on De Zavala Point (41 HR 32, 41 HR 40, and 41 HR 41). These she11 middens are the earliest evidence of occupation at De Zavala Point. Collected materials indicate that these sites may date to the Ceramic period, though this assessment is tentative. Additional1y, five prehistoric shell middens (41 HR 37, 41 HR 38, 41 HR 42, 41 HR 43, and 41 HR 44) were recorded by Neyland and Worthington along the banks of the $01 d$ River in the vicinity of the study site. Shel1 middens within the project area are densely packed lenses of Rangia cuneata shel1 in a matrix of dark organic-stained soil, and are the remains of seasonal campsites where brackish water clams were collected and processed. Such exploitation of shel1 food resources appears to have been most intense in shallow brackish water lakes and bays with in the estuarine environment (McGuff and Ford 1974:19-20, 22).

Although on $7 y$ the southern tip of site 41 HR 39 extended into the 1982 project area, eroded shel is from the site were scattered throughout the vicinity. The Rangia she 11 midden deposits at site 41 HR 39 were reported to be $65 \mathrm{~cm}$ thick along approximately $200 \mathrm{~m}$ of the rapidly eroding northern b 1 uff of De Zavala Point. Aboriginal ceramics and 1 ithic materials were observed in the midden deposits. Uncontrolled surface collections recovered early historic artifacts in addition to prehistoric materials, including a Perdiz arrow point and a San Jacinto Plain (or, Baytown Plain, variety San 
Jacinto; Aten 1983a:239-241) ceramic sherd in the vicinity of site 41 HR 39. A dirt road which crossed the site did not appear to have disturbed the midden deposits (Aronow 1982; Brandimarte 1982; Day 1982; Voel1inger 1982). Site 41 HR 423, a late 19th-century homesite, located on the southern end of site 41 HR 39, exhibited smal1 shel1 1enses, and had both prehistoric and historic materials, including an undecorated gray sherd and two chert chips, an intact course of handmade bricks, a purple glass bottle stopper, and metal fragments suggestive of a 1ate 19th-century/early 20th-century site (Voe1 1 inger 1982:12).

Site 41 HR 32 is described as a severely eroded prehistoric she 11 midden and the location of the Lorenzo de Zavala homesite (Brandimarte 1982; Day 1982; Fox 1982:1-2; Voel1inger 1982:3). Artifacts recovered from the site, however, general1y date to the 1 ate 1800 s and 1 ater (Voe 11 inger 1982:10, citing Black 1982 and Ful1en 1982; Fox 1982). The investigations by Voe 11 inger (1982), Brandimarte (1982), and Day (1982), could not determine the precise location of the De Zavala homesite, but the available evidence did suggest that it was located on high 1 and on the south side of De Zavala Point, adjacent to Buffalo Bayou. The house was smal1 and served as a hospital after the Battle of San Jacinto. The structure burned down sometime between 1860 and 1870. Severe erosion and subsidence of this area may have destroyed the archaeological remains of the original homesite. The remains of the homesite are probably not currently located in the project area on the north side of De Zavala Point, but it is possible that the archaeological remains of homesites and other structures associated with occupation and utilization of De Zavala Point may have once been present in the project area (Brandimarte 1982; Fox 1982; Voel 1 inger 1982:3, citing Houston Post n.d., and De Zavala 1934; Department of the Army, Galveston District, Corps of Engineers 1984).

Another historical site recorded during the 1982 archaeological investigations was the San Jacinto Ordnance Depot (41 HR 424), established in 1939 by the United States Navy, which has features such as cement sidewalks and steps, brick piers, and she11-topped roads. Piles of recent trash found throughout the project area along the existing shel 1 roads evidenced the use of the Point as a dump (Day 1982).

In 1984, staff archaeologists for the Department of the Army, Galveston District, Corps of Engineers conducted an inspection of site 41 HR 39 (Stokes 1984) in conjunction with the processing of Department of the Army Permit Application No. 17151, 01d River Fleet and Shipyard, applicant, to dispose of dredged materials on the northern shore of De Zavala Point where site 41 HR 39 is 1ocated. Eight auger tests dug by the archaeologists showed that the shell midden stratum was beneath up to $65 \mathrm{~cm}$ of recently deposited fill in the northeastern part of the site study area. The she11 midden stratum was exposed at the surface and eroding in the southwest part of the permit area. The test results indicated that portions of the site remained intact. On the basis of this investigation, it was recommended that the site be tested to determine its eligibility for the National Register of Historic Places. 


\section{RESEARCH GOALS AND METHODS}

The primary goal of this project was to test site 41 HR 39 to obtain sufficient information to determine its eligibility for the National Register of Historic P1aces. The site is to be impacted by the disposal of dredged material during industrial development by the 01d River Fleet and Shipyard, the current owners of the site property.

Investigations conducted during this project were intended to provide the following information, if possible: the site limits, cultural stratigraphy, chronology, and potential to yield additional significant information. Cultural features and special use areas within the site were to be identified. Information gained from the analysis of tools and faunal materials recovered from the site would be used to identify subsistence strategies, including a seasonality study of Rangia cuneata she11. Final1y, the relationship between site 41 HR 39 and other such sites in the project area was to be estab 1 ished (Department of the Army, Galveston District, Corps of Engineers 1984).

The first task performed for the project was the survey and mapping of the project area. A transit and stadia rod were used to make a contour map of the site which included the excavation areas, and to set a metric horizontal grid system aligned with magnetic north across the site to provide horizontal control. Al1 elevations were calculated relative to a site datum set at a concrete base for the fence which marks the property 1 ine of the adjoining Falcon Cement, Inc., operation (Figs. 2; 3 ). Elevations shown on the site map (Fig. 2) were calculated using the current shoreline 1 evel as $0.0 \mathrm{~m}$ elevation. The beach face and the site area were examined to determine the extent of a11 exposed she11 deposits within the project area. These exposures were used to roughly define the site 1 imits and to help determine the placement of excavation pits, units, and trenches.

The testing strategy included backhoe trenching to initially define the site boundaries and to locate areas which had potentially intact remains. Five backhoe trenches were excavated during the project. The color of the soil exposed in the backhoe trenches was determined in the 1 aboratory using Munse 11 Soil Color Charts (1975) from soil samples collected from the trench profiles during field operations. In addition, five backhoe test pits and nine shovel tests were dug to further determine the site 1 imits (Fig. 2 ). Since the purpose of the shovel tests was to determine the extent of the subsurface shel 1 midden, they were dug in single levels and were excavated to sterile clay subsoil, or through dredged clay to a depth considered sufficient to determine that the she11 midden deposit was not present. The soil from the shovel tests was hand sorted using trowels and shovels, rather than being screened, due to the clayey nature of the soil. Cultural materials from what appeared to be recently dredged soil were not collected, considering the recent introduction of such items.

Cultural deposits exposed by the backhoe operations, which appeared to be in situ, were investigated with hand-excavated units. Only two $1-\mathrm{m}^{2}$ units, N40/W36 and N48/W33, were dug because of the evidence of disturbance in the she 11 midden deposits at the site. The two units were located in areas which appeared to have the most intact and abundant shel1 midden deposits, near 
backhoe trenches 4 and 5 (Fig. 3) in the northeastern part of the project area. The test units were dug in natural levels which were subdivided in arbitrary levels. Each level was recorded on a printed CAR-UTSA unit-1evel record. The levels in the two units were recorded differently. The dredged clay in unit N40/W36 was designated as level 1 , and the underlying levels in the shel1 midden were designated as 1 evels 2 and 3 . In unit N48/W33, the dredged clay was not designated as a level, and the two levels in the shel1 midden deposit were recorded as levels 1 and 2. The dredged clay overlying the shell midden stratum was shoveled out and not screened due to the disturbed nature of the deposit. Materials recovered from the hand-excavated test units were water screened using 1/4-inch mesh hardware cloth overlying 1/8-inch fine mesh. The water was pumped from the 01d River. In addition to cultural materials, a 11 the shel1 and bone from the test units was collected. Because there was an admixture of numerous pieces of recent wood and charcoal, and other recent historic materials into the shel1 midden stratum, no samples were coll lected of charcoal for radiocarbon dating. Both test units were excavated to the sterile clay subsoil. In unit N40/W36 (or unit 1), the excavation levels were as follows: level 1, dredged clay, existing ground surface to $12 \mathrm{~cm}$ below ground surface; level 2, shel1 midden deposit, 12-27 cm below ground surface; 1eve1 3, she11 midden deposit, 27$37 \mathrm{~cm}$ below modern ground surface. The excavation levels in unit N48/W33 were as follows: (no level) dredged clay, existing ground surface to $13 \mathrm{~cm}$ below ground surface; level 1 , shel1 midden deposit, $13-28 \mathrm{~cm}$ below ground surface; level 2, $28-36 \mathrm{~cm}$ bel ow ground surface.

A1 1 excavated areas were backfilled at the completion of the project using a backhoe. Modern markers such as aluminum cans were placed in the bottom of the excavations prior to backfilling with stockpiled backdirt.

Prehistoric artifacts, mainly sherds, and historic artifacts were collected from the site surface and from the beach and slumping shel1 midden deposits along the banks of the site. This was done to add to the artifact sample and thereby aid in determining the chronology of shell midden deposits at the site.

Daily field journals were kept by al1 members of the CAR-UTSA field crew, including the field director. Records were kept of backhoe and hand-dug excavations, including stratigraphic profiles, and photographs were taken of the general site and of the excavations.

After the completion of the field work al1 the collected materials were taken to the CAR-UTSA for 1 aboratory processing and analysis. A11 these materials, in addition to al1 the notes, records, and photographs generated during the project are curated at the CAR-UTSA.

\section{SITE DESCRIPTION}

During the 1982 investigations, 41 HR 39 was described as an extensive shel1 midden which extended for several hundred meters along the north and east shores of De Zavala Point (Voel1inger 1982; Day 1982). Since 1982, however, industrial development of the Point has severely modified the vicinity. 
Since 1982, a large concrete storage silo was constructed on the southern half of the Point by Falcon Cement, Inc. (Permit Application No. 16000). At approximately that same time, the 01d River Fleet and Shipyard acquired the northern half of the Point and constructed a brick office building and a corrugated metal utility structure and dug trash pits on the northern side of the utility structure. One of the trash pits measured roughly $2.8 \mathrm{~m} \times 3 \mathrm{~m}$, and the other measured $3 \mathrm{~m} \times 3.5 \mathrm{~m}$ in diameter. Nearly all the thick forest overgrowth which formerly covered the Point was removed, and much of the 1 and surface appears to have been bladed or covered with fill (Stokes 1984). A 7 arge pile of dredged material is on the northwestern part of the project area, and covers part of the site (Figs. 2; 3; 4,a,b). Jack Lili ard, an employee of the 01d River Fleet and Shipyard, told the archaeologists that the pile of dredged material dated to 1983, and consisted of materials which had slumped from the north bank of the Point, and that the trash pits were dug at that same time. Large pieces of concrete, metal, plastic, crushed gravels, and other industrial debris are situated on the southern part of the project area. Most of the eroding she 11 midden stratum of $41 \mathrm{HR} 39$, which occurred along the north bluff, was destroyed during the installation of a I$\mathrm{m}$ high bulkhead in this area. James Bradley, an employee of the $01 d \mathrm{River}$ Fleet and Shipyard, told the archaeologists that the "best part" of the site (4I HR 39) was removed for the construction of the metal bulkhead and post pier on the northwest side of the site. The smal1 isolated segments that were preserved of this midden stratum along the north bluff are slumping rapidly down slope (Figs. $4, a ; 5, a, b)$. A dense surface scatter of Rangia she $11 \mathrm{~s}$, oyster she $11 \mathrm{~s}$, and prehistoric and historic artifacts marked the erosion of the southeastern part of site 41 HR 39 (Figs. 4,a,b); these eroding materials extended into the area investigated by Voel1inger (1982) and Day (1982). An investigation by Jan Stokes and Carolyn Good (Stokes 1984), staff archaeologists for the Department of the Army, Galveston District, Corps of Engineers, which is reviewed earlier in this report, indicated that intact deposits were preserved at site 41 HR 39.

James Bradley of Channelview (personal communication 1984) reported finding several projectile points from the sandy trash pit area, west of the $01 d$ River Fleet and Shipyard metal utility building. He said that the sand in this area accumulated from sand blasting. Bradley also stated that artifacts relating to the World War II military occupation of De Zavala Point had been recovered from the area between the metal utility building and the brick office building. Bradley's information concerning the site would have been gained recently during his employment at the $01 d$ River Fleet and Shipyard.

Jack Lillard of Channelview (personal communication 1984) told the archaeologists that brick firing had been done in the area, which might explain the crumbling, over-fired bricks and brick fragments found on the site. These brick fragments, however, may have been from demolished structures, and probably were manufactured at nearby Cedar Bayou, as discussed further in this report. Like Bradley, Lillard has been present at De Zavala Point for only one or two years, since his employment at the old River Fleet and Shipyard.

Disturbance at the site has been caused by various activities associated with the repeated nonaboriginal occupation, utilization, and abandonment of the Point since the $1820 \mathrm{~s}$ or $1830 \mathrm{~s}$. These activities include the recent 
deposition of a pile of dredged material in the northwest part of the project area; a layer of dredged clay in the north and northeastern parts of the project area; trash dumping, especially visible in the south and west parts of the project area; erosion, particularly evident along the shorelines and in the southeast part of the project area; and subsidence of the Point. The depositional sequence at the site was further complicated by the presence of a she11-topped road, now partially covered with dredged material, which foll lowed the banks of De Zavala Point including the site (4I HR 39) area, and possibly extended in 1 and. Lenses of crushed she 11 observed in the she 11 midden stratum of backhoe trench 5 (Fig. 3) appeared to be part of that road.

De Zavala Point gently slopes from south to north, and an eroding compound slope goes from west to east on the southeastern part of the project area. The Rangia shel1s exposed on the surface in the southeastern part of the site (Fig. 2) appear to have eroded from the intact deposits in the northern part of the site since no subsurface shel1 midden deposits were found in the tests dug in this area.

\section{THE EXCAVATIONS}

Shovel tests 1-6 (Table 1), predominantly located in the southern part of the project area (Fig. 3), revealed eroding, disturbed deposits in the vicinity of the 01d River Fleet and Shipyard metal utility building. Shovel test 9 showed clayey dredged material in the southeastern part of the project area, near the east beach face. Shovel tests 5 and 6 , along the north bank in the northwestern part of the project area, showed clayey, dredged material.

The stratigraphy of the northwestern part of the project area where backhoe trenches 1-3 (Figs. 6-8) were excavated is variable. In backhoe trench 1 (Fig. 6), the stratigraphy is composed of an upper deposit of sandy clay (recently dredged materia1), from $5 \mathrm{~cm}$ to $20 \mathrm{~cm}$ thick, overlying a $5 \mathrm{~cm}$ to $10 \mathrm{~cm}$ thick deposit of sandy clay loam with Rangia shel1s, prehistoric ceramics, and historic materials. The sandy clay loam stratum overlies another deposit of sandy clay loam with a higher sand content, which is from $17 \mathrm{~cm}$ to $125 \mathrm{~cm}$ thick, and includes a few pieces of she11. The lower strata, which contain no cultural materials, are deposits of sandy clay which become more clayey with increased depth.

In backhoe trench 2 (Fig. 7), the stratigraphy includes a $5 \mathrm{~cm}$ to $30 \mathrm{~cm}$ thick upper deposit of sandy clay loam with a high clay content and a few Rangia she11s, prehistoric ceramics, and historic materials. The underlying, $5 \mathrm{~cm}$ to $25 \mathrm{~cm}$ thick stratum is a sandy clay $10 \mathrm{~mm}$ with a high sand content, more Rangia shel 15 than the overlying level, prehistoric sherds, and historic materials. The underlying, $22 \mathrm{~cm}$ to $50 \mathrm{~cm}$ thick stratum is a clay loam with no cultural materials. The deeper strata are sterile clay.

The upper stratum in backhoe trench 3 (Fig. 8) is a sandy clay loam with a high clay content, which varies from $5 \mathrm{~cm}$ to $100 \mathrm{~cm}$ in thickness. The underlying stratum in the east and west ends of the trench (Fig. 8,a,c) is a sandy clay with no cultural materials, which becomes more clayey with increased depth; this stratum was not visible in the central part of the trench, though it may occur at a depth below where this part of the trench 
TABLE 1. SHOVEL TEST DESCRIPTIONS

\begin{tabular}{|c|c|c|}
\hline Shovel Test & Depth & Description \\
\hline 1 & $\begin{array}{r}0-6 \mathrm{~cm} \\
6+\mathrm{cm}\end{array}$ & $\begin{array}{l}\text { eroded, sandy clay loam, Rangia she } 11 \mathrm{~s} \text {, and } \\
\text { glass } \\
\text { clay }\end{array}$ \\
\hline 2 & $\begin{array}{r}0-41 \mathrm{~cm} \\
41+\mathrm{cm}\end{array}$ & $\begin{array}{l}\text { sandy clay loam with brick, Rangia she } 11 \mathrm{~s} \text {, and } \\
\text { glass } \\
\text { clay }\end{array}$ \\
\hline 3 & $\begin{array}{r}0-10 \mathrm{~cm} \\
10-29 \mathrm{~cm} \\
29+\mathrm{cm}\end{array}$ & $\begin{array}{l}\text { sandy loam } \\
\text { sandy clay loam } \\
\text { clay }\end{array}$ \\
\hline 4 & $0-46+\mathrm{cm}$ & clay \\
\hline 5 & $0-45+\mathrm{cm}$ & sandy clay with petroleum sme11 \\
\hline 6 & $\begin{array}{r}0-10 \mathrm{~cm} \\
10-46+\mathrm{cm}\end{array}$ & $\begin{array}{l}\text { sandy } c l \text { ay with Rangia she } 1 \mathrm{ls} \text { and glass } \\
\text { sandy clay with petroleum sme } 11 \text {, clay content } \\
\text { increases with depth }\end{array}$ \\
\hline 7 & $\begin{array}{r}0-15 \mathrm{~cm} \\
15-18 \mathrm{~cm} \\
18-34+\mathrm{cm}\end{array}$ & $\begin{array}{l}\text { clay loam, crushed and burned Rangia shel } 1 \\
\text { fragments, mineralized bone fragments--highly } \\
\text { disturbed } \\
\text { clay loam grading into clay } \\
\text { clay }\end{array}$ \\
\hline 8 & $\begin{array}{r}0-10 \mathrm{~cm} \\
10-33 \mathrm{~cm} \\
33-70+\mathrm{cm}\end{array}$ & $\begin{array}{l}\text { sandy clay loam, Rangia shells } \\
\text { sandy clay loam } \\
\text { sandy clay, clay content increases with depth, } \\
\text { chert flake at ca. } 40 \mathrm{~cm}\end{array}$ \\
\hline 9 & $0-40+\mathrm{cm}$ & clay \\
\hline
\end{tabular}



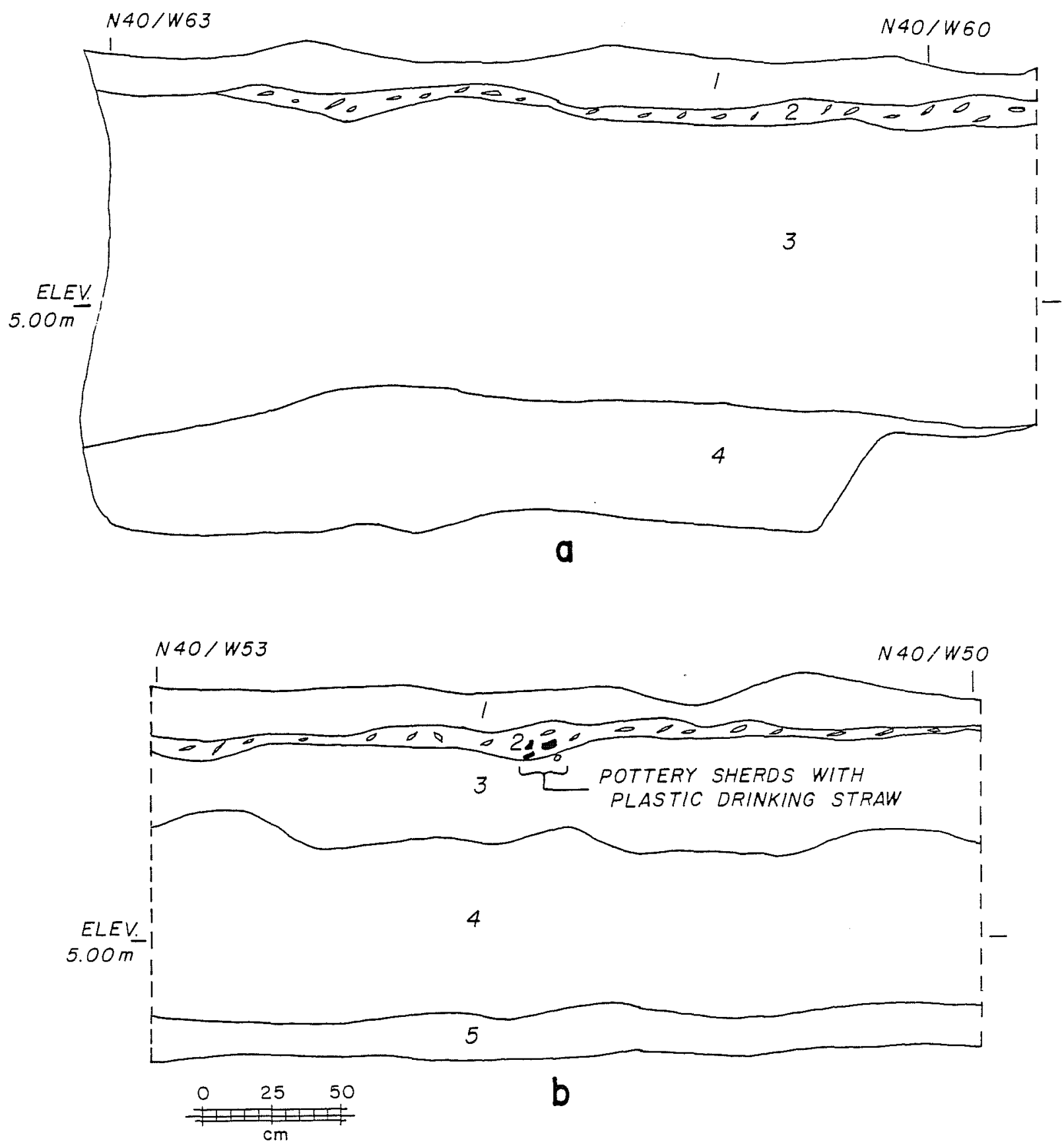

Figure 6. Backhoe Trench 1, North Profile. a, N40/W60-63, west end of trench; $b$, N40/W50-53, east part of trench. The strata are as follows: (1) Dark yellowish brown (10 YR 3/4) sandy Clay with red (10 YR 4/8) mottling. (2) Dark brown (10 YR 3/3) sandy clay Toam with Rangia shel 1s, and prehistoric and historic materials. This stratum is the shell midden deposit. (3) Dark brown (10 YR 3/3) to dark yel1owish brown (10 YR 3/4) sandy clay loam with a high sand content, and a smal1 amount of shel1. (4) Dark yellowish brown (10 YR 4/4) sandy clay with a high sand content, and historic materials and she 11. (5) Pale brown (10 YR 6/3) sandy clay with dark red (2/5 YR 3/6) and yellowish brown (10 YR 5/8) mottling. 

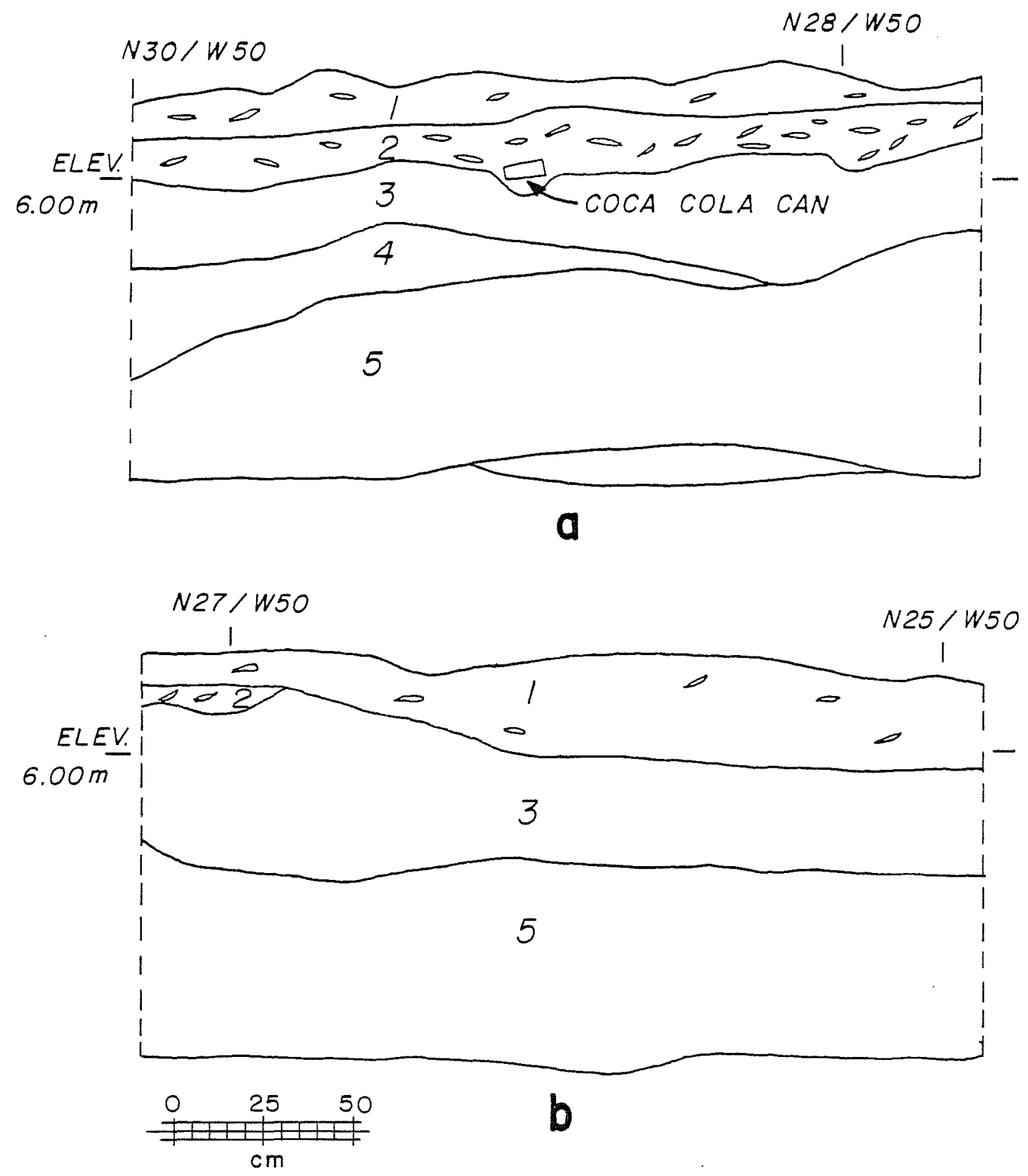

Figure 7. Backhoe Trench 2, East Profile. a, N28-30/W50, north end of trench; b, N25-27/W50, central part of trench. The strata are as fol lows: (1) Dark yellowish brown (10 YR 3/4) sandy clay loam with a low sand content and a few Rangia shel 1s. (2) Dark yellowish brown (10 YR 3/4) sandy clay loam with a high sand content, and a higher count of Rangia shel ls than stratum 1. Prehistoric and historic materials occur in this stratum. This stratum is the shell midden deposit. (3) Dark brown (10 YR 3/3) clay loam. (4) Dark yel lowish brown (10 YR 4/4) clay. (5) Pale brown (10 YR 6/3) clay with dark red (2.5 YR 3/6) and yel lowish brown (10 YR 5/8) mott 1 ing, and a few small pebbles. (6) Grayish blue clay. (No sample was taken of this stratum for a Munse11 soil color reading.) 
was excavated. Beneath the upper stratum in the central part of the trench (Fig. $7, b)$ is a $2 \mathrm{~cm}$ to $10 \mathrm{~cm}$ thick stratum of sandy clay loam with a few Rangia shel1s; this stratum appeared to have been compacted. Underlying this stratum is another deposit of sandy clay loam that is lighter in color, has more she11, and includes flecks of charcoal; this lower deposit appeared to be part of the shell midden deposit, and did not appear to be compacted, unlike the stratum which overlies it. Beneath this stratum, in the central part of the trench ( $F$ ig. $8, b$ ), is a stratum of sandy clay loam with a high clay content which overlies sandy clay deposits; no cultural materials were found in these deposits.

In backhoe trenches 4 and 5 (Figs. 9; 10), the northeastern part of the project area, the shel1 midden deposits were best preserved. In backhoe trench 4 (Fig. 9) the upper stratum consists of a $5 \mathrm{~cm}$ to $25 \mathrm{~cm}$ thick 1 ayer of dense, mottled clay which was dredged materia 1; a layer of grass and other organic materials was visible at the base of this deposit marking the former ground surface. The next stratum is a 100 se sandy $\mathrm{clay}$, from $2 \mathrm{~cm}$ to $55 \mathrm{~cm}$ thick, which overlies a $2 \mathrm{~cm}$ to $20 \mathrm{~cm}$ thick, sandy clay loam deposit with Rangia shel1s, prehistoric ceramics, and historic materials. In some parts of the trenches the she 11 is sandwiched between 1 ayers of dark sandy clay loam, while in other parts the shel1 and the sandy clay loam are intermixed. The underlying stratum is a $5 \mathrm{~cm}$ to $75 \mathrm{~cm}$ thick deposit of sandy clay with fragments of crushed, weathered she11, but no cultural materials. Beneath this stratum is a strata of sand and a strata of dense clay, neither of which contain cultural materials.

In the northern and southern parts of backhoe trench 5 ( $F$ ig. 10,a,c) the upper stratum is a $15 \mathrm{~cm}$ to $55 \mathrm{~cm}$ thick deposit of clay with a few Rangia shel1s (recently dredged material). In the central part of the trench (Fig. 10,b), however, this clayey, dredged deposit is overlain by a $40 \mathrm{~cm}$ to $45 \mathrm{~cm}$ thick layer of sandy clay loam which has a high clay content, sme $11 \mathrm{~s}$ of diesel oil, and contains a few Rangia shel1s and decaying organic materials; the location of this 1 ayer above dredged material indicates that its deposition occurred recently. Underlying these deposits is a $5 \mathrm{~cm}$ to $45 \mathrm{~cm}$ thick stratum of sandy clay loam with a high clay content, containing many Rangia shel1s, and also prehistoric and historic materials; this stratum is the shell midden deposit. The shell midden deposit was not visible in the central part of the trench ( $F$ ig. $10, b)$, however. Within the shel1 midden 1 ayer is a lens of crushed she11 (Fig. 10,a) with a maximum thickness of $15 \mathrm{~cm}$, which may have formerly been part of a she11-topped road. There is what appeared to be a tree root disturbance through the she 11 and $10 a m y$ deposit in the northern part of backhoe trench 5 (Fig. 10,d). In the northern part of the trench (Fig. 10, c, d), the she11 midden deposit is overlain by a $2 \mathrm{~cm}$ to $15 \mathrm{~cm}$ thick deposit of sandy clay loam which is similar to the underlying shel1 midden deposit, but which has thin lenses of sand and a 1esser amount of Rangia she115; this 1 ayer may represent part of the she 11 midden which has eroded. Underlying the shel1 midden deposit in the southern and central parts of the trench ( $F$ ig. $10, a, b$ ) is a $5 \mathrm{~cm}$ to more than $60 \mathrm{~cm}$ thick stratum of sterile clay; this clay 1 ayer does not extend to the northern end of the trench ( $F$ ig. 10,c,d). A stratum of sandy clay with fragments of crushed, weathered shel1 underlies the sterile clay stratum in the southern part of the trench ( $F$ ig. 10,a). This layer of sandy clay underlies the shell midden deposit in the northern end of the trench 
Figure 8. Backhoe Trench 3, North Profile. a, N15/W52.25.-55, east part of trench; b, N15/W60-63, central part of trench; $c$, N15/W70-73, west part of trench. The strata are as follows:

(1) Light brownish gray (10 YR 6/2) sandy clay loam with a high sand content.

(2) Light gray (10 YR 7/2) sandy clay with yel1owish brown (10 YR 5/8) mottling. The clay content increases with depth.

(3) Very dark grayish brown (10 YR 3/2) sandy clay loam with a few Rangia she17s. This stratum is layered and compacted.

(4) Lighter grayish brown sandy clay loam (in comparison to stratum 2) with a moderate amount of Rangia shells and charcoal flakes. This stratum is the she 11 midden deposit. (No sample was taken of this stratum for a Munsell soil color reading.)

(5) Light brownish gray (10 YR 6/2) sandy clay loam with a high sand content.

(6) Light gray ( 10 YR 7/2) sandy clay with a moderate sand content and with yellowish brown (10 YR 5/8) mottling.

(7) Light gray (10 YR 7/2) sandy clay with red (2.5 YR 4/6) mottling. 

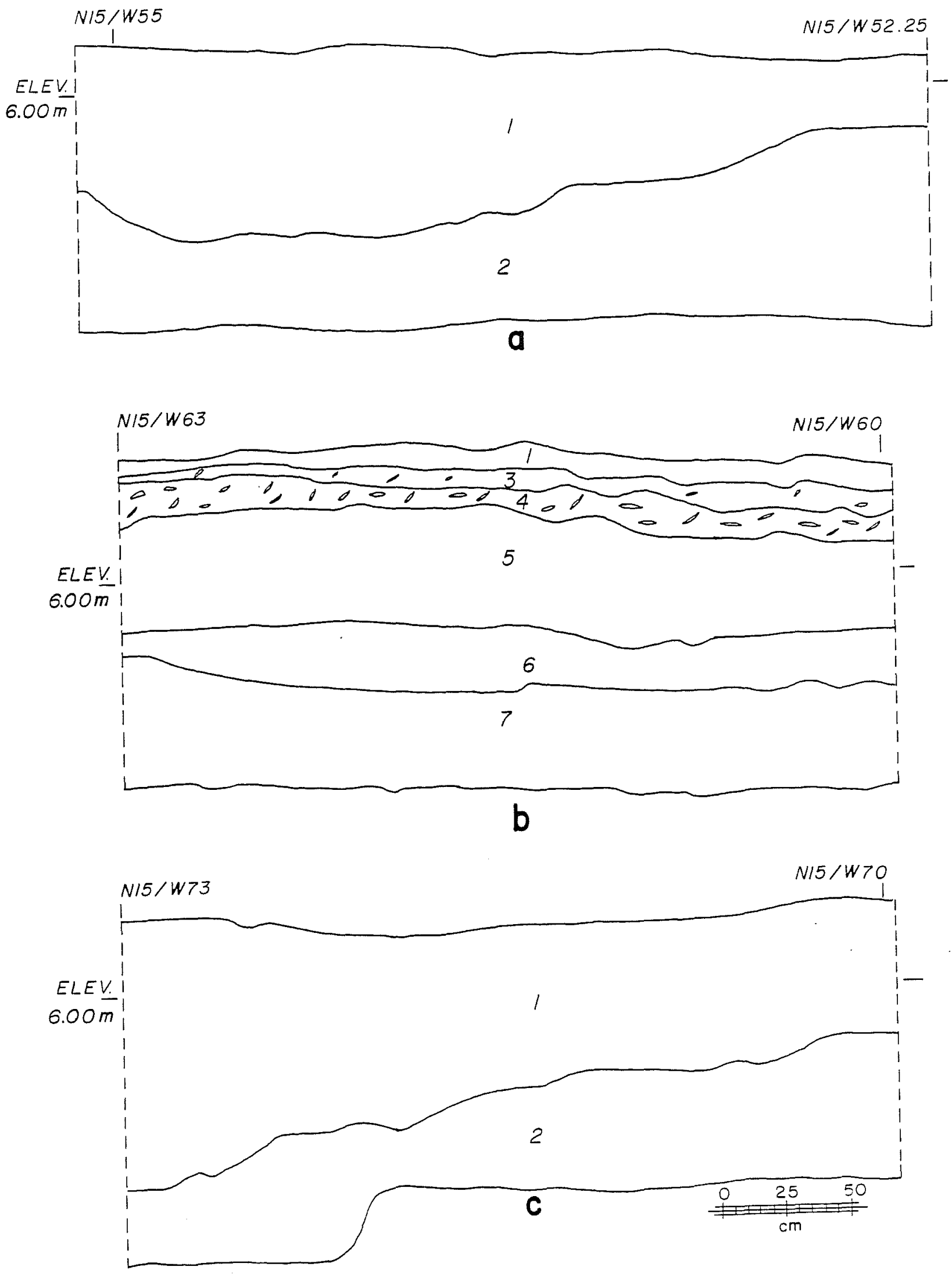
Figure 9. Backhoe Trench 4, South Profile. a, N40/W26-29, east end of trench; b, N40/W35-37, central part of trench; $c$, N40/W4043, west of end of trench. The strata are as follows:

(1) Dense red (2.5 YR 4/8), brown (10 YR 5/3), and very dark grayish brown (10 YR 3/2) mottled clay with a few Rangia she11s. This stratum is recently dredged clay.

(2) Very dark grayish brown (10 YR 3/2) sandy Clay loam with a high clay content, roots, decaying wood, and a very few Rangia shells.

(3) Very dark gray (10 YR 3/1) sandy clay loam with a high clay content, with many Rangia shel1s, and prehistoric and historic materials. This stratum is the shell midden deposit.

(4) Light yel10wish brown (2.5 YR 6/4) sandy clay with crushed, weathered she1 1 fragments.

(5) Very pale brown (10 YR 7/4) sandy clay with yellowish red (5 YR 5/8) motti ing.

(6) Tan sand. (No sample was taken of this stratum for a Munsel1 soil color reading.)

(7) Dark greenish gold dense clay. (No sample was taken of this stratum for a Munsel1 soil color reading.) 

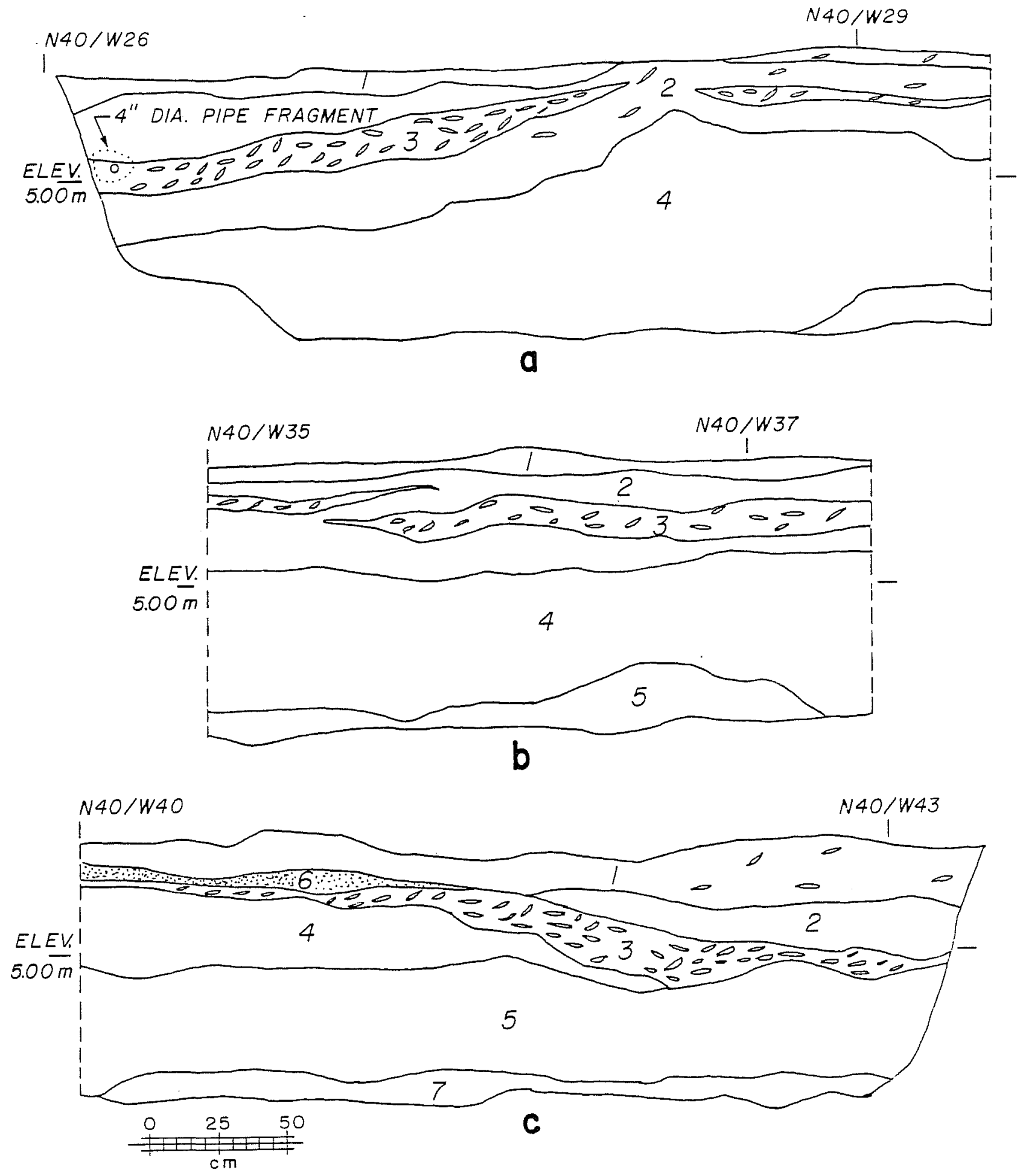
Figure 10. Backhoe Trench 5, West Profile. a, N28-30/W25, south part of trench; b. N35-39/W25, south-central part of trench; $c$, N46-47/W25, north-centra 1 part of trench; d, N50-51/W25, north part of trench. The strata are as follows:

(1) Dense red (2.5 YR 4/8), brown (10 YR 5/3), and very dark grayish brown (10 YR 3/2) mottled clay with a few Rangia shel1s. This stratum is recently dredged clay.

(2) Very dark grayish brown (10 YR 3/2) sandy clay loam with a high clay content, roots, decaying wood, and very few Rangia shel1s.

(3) Very dark gray (10 YR 3/1) sandy clay loam with a high clay content, with many Rangia shel1s, and prehistoric and historic materials. This stratum is the shel1 midden deposit.

(4) Light olive brown (2.5 YR 5/4) clay with red (2.5 YR 4/8) mottling.

(5) Light yel lowish brown (2.5 YR 6/4) sandy clay with crushed, weathered shel1 fragments.

(6) Very dark gray (10 YR 3/1) layered sandy clay loam with historic materials. This stratum smelled strongly of diesel 0 il.

(7) The same soil as stratum 3, but with thin 1 enses of tan sand, and on 1 y a few Rangia shells.

(8) The same soil as stratum 3, but with thin 7 enses of tan sand, and only a few very smal1 Rangia shell fragments. This deposit appeared to have resulted from tree root disturbance. 

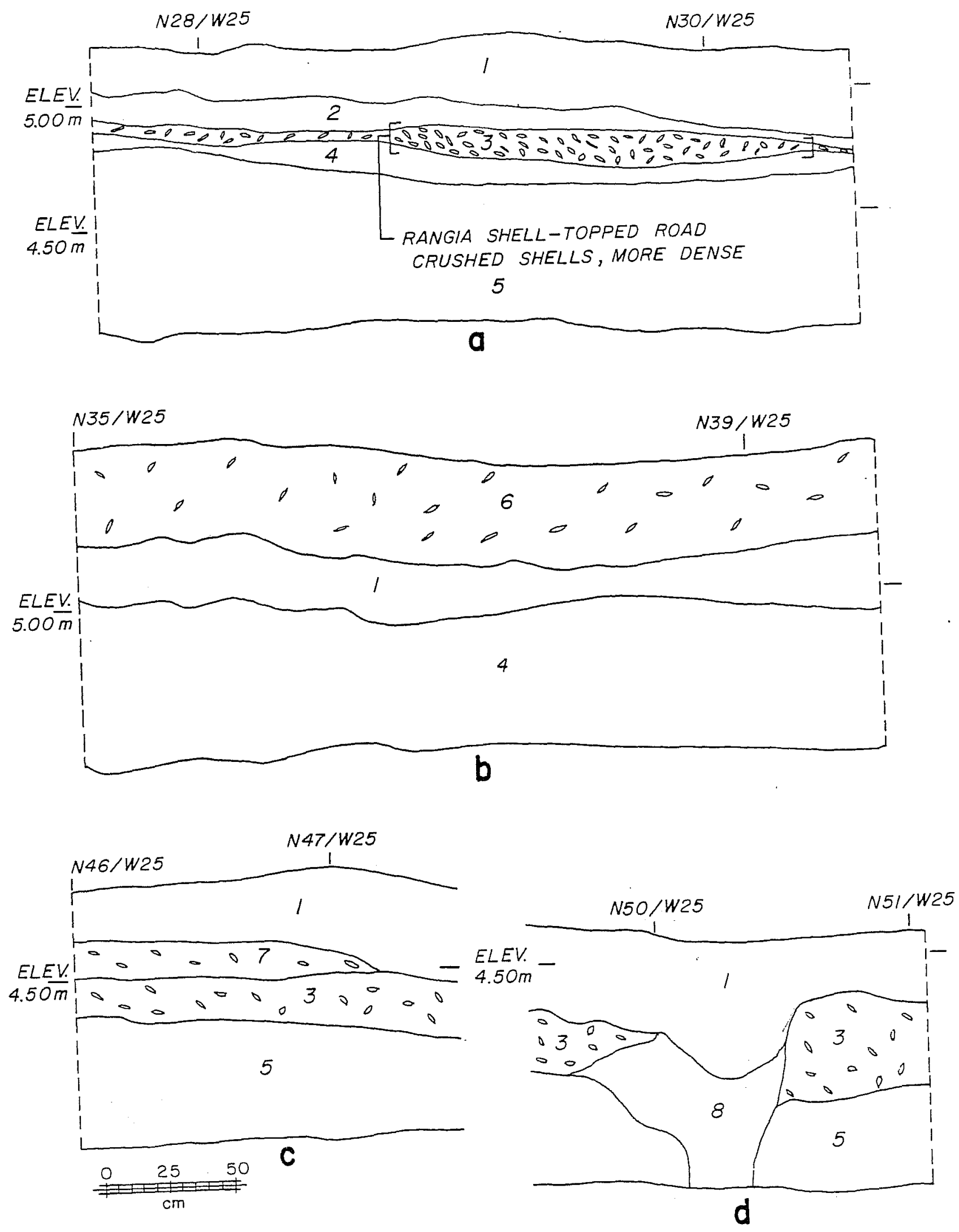

(Fig. 10,d), but was not observed in the central part of the trench (Fig. 10,b).

Judging from the excavation results, the intact she 11 midden deposits of 41 HR 39 are predominantly in the northeastern part of De Zavala Point, in the vicinity of backhoe trenches 4 and 5 of excavation units N40/W33 and N48/W36. The portion of the site which is preserved within the study area appears to measure rough 7 y $30 \mathrm{~m} \times 40 \mathrm{~m}$. Though relatively thick shel 1 midden deposits occur along the northern bank of De Zavala Point, west of backhoe trenches 4 and 5 and the excavation units, the additional backhoe trenches (1-3), backhoe test pits, and shovel tests show that these deposits do not extend southward from the bank into the Point. An additional remnant of the site was located by Day (1982), in the southern part of De Zavala Point, in backhoe trenches 9 and 10. This southern remnant of the site was covered by as much as $60 \mathrm{~cm}$ to $125 \mathrm{~cm}$ of recent overburden, however, in comparison to $35 \mathrm{~cm}$ of overburden found in backhoe trenches 4 and 5 within the present project area.

\section{MATERI ALS RECOVERED}

The materials recovered from the site are divided into prehistoric and historic categories. The prehistoric materials are ceramics, 1 ithics, all faunal materials, and al1 the fine screen materials; some of the faunal materials and fine screen materials included in the prehistoric section date to the historic component, however. The historic materials are ceramics, glass, metal, and miscellaneous materials such as stone and plastic.

The provenience of the material is as follows. The surface collection category includes al1 materials collected from the surface of the southern part of the site, and from other parts of the site but for which specific provenience was not recorded. The northwest (NW) quad category is materials collected from the surface of the northwestern part of the site and also from the eroding deposits exposed along the north bluff and the sea wall or pier on the northern side of the site; materials collected from the north shore of the site along the 01d River were also included in this category. Materials collected from the pile of dredged material on the north side of the site are designated as such. Specific collection stations or areas from the backdirt of the northern part of backhoe trench 5 (collection stations 5-1 and 5-2). are also designated; the backdirt was consistently placed near the area from which it was excavated, so collections from these trench stations (which were mapped during the project) are from known areas of backhoe trench 5 . ST 1 designates shovel test 1 . Materials from the controlled excavation units, N40/W36 and N48/W33, are assigned to specific levels.

\section{PREHISTORIC MATERIALS}

The prehistoric cultural materials recovered during this project are 613 sherds, 401 ithics, and two pieces of worked bone. 



\section{Ceramics}

The prehistoric ceramics are categorized and discussed in terms of paste, temper, decoration, and vessel part (Table 2; Figs. 11-13). Aten's (1983a) ceramic classifications for the Galveston Bay area were assigned to sherds for which distinct types could be distinguished. The surface and interior (as shown in a fresh break) of a 11 the sherds were examined using $10 \mathrm{X}$ and $16 \mathrm{X}$ magnification. There were 592 sandy paste sherds, six sherds which may be she 11-tempered, and 15 grog-tempered sherds. Overal1, thinner sherds were approximately $0.4 \mathrm{~cm}$ thick, and general1y had a finer paste. Thicker sherds were roughly $0.65 \mathrm{~cm}$ thick, and generally had a more coarse paste. A brief examination of body sherd thickness indicated that the sandy paste body sherds genera11y average $0.65 \mathrm{~cm}$, she11-tempered $0.61 \mathrm{~cm}$, and grog-tempered $0.71 \mathrm{~cm}$. Sandy paste rim sherds vary from $0.5 \mathrm{~cm}$ to $0.8 \mathrm{~cm}$ in thickness, averaging rough 1 y $0.65 \mathrm{~cm}$. There were no she 11-tempered rim sherds. The single grog-tempered rim sherd recovered was $0.70 \mathrm{~cm}$ thick. Some sherds have blackened interiors, possibly from deliberate sooting or smudging.

\section{Sandy Paste Ceramics}

The upper Texas coast sandy paste plainwares are generally classified as one type, Goose Creek Plain, because of the similarity of such ceramics throughout southeast Texas and southwestern Louisiana. Local varieties of sandy paste ceramics are defined as a division of Goose Creek Plain (Aten 1983a:217). Goose Creek P1ain vesse1 1ip types which were distinguished in the study collection were thinned, flattened, and rounded. Lip notching occurred on flattened rims in a 11 cases for Goose Creek Plain rim sherds (Fig. 11,b,c). Suhm, Krieger, and Jelks (1954:378) state that most rim sherds have a thinned, or sharp, edge (or $1 \mathrm{ip}$ ). Some rim sherds are turned outward, and some exhibit 1 ip notching, which is fairly common. The 1 ip notching on Goose Creek Plain rim sherds in the study sample extended across the vessel 1 ip at a right angle. Lip notching on Goose Creek Incised rim sherds was present only along the interior 1 ip edge and a 7 ways appeared in combination with horizontal, parallel 1 ines which were on the exterior of the rim (Fig. 12,a,c). Vessel bases were conical and were characterized by a thick knob. Although whole vessels from this area are rare, three forms are known to be present: deep hemispherical bowls which are up to $45 \mathrm{~cm}$ in diameter, cylindrical vessels which are $25 \mathrm{~cm}$ or more in height, and generally cylindrical vessels which curve slightly inward between the middle and the mouth (ibid., citing Wheat 1953:P1ate 31). Dri11 holes may occur immediately below the $1 \mathrm{ip}$, or in pairs, on either side of a crack and were probably used for vessel repair (Suhm, Krieger, and Jelks 1954:378).

The sand in the sandy paste sherds from site 41 HR 39 grades from very fine with a homogeneous texture and fine, thin layers or 1 enses of sand, to a coarse, 1 arge grain paste. Most sherds have a coarse paste, a very few have a uniform fine paste, and more sherds have a medium grain size paste than have a fine paste. The medium paste sherds appear to have a contorted, poorly wedged paste texture. Since there was a gradation of sherd pastes rather than a distinct division, all the sandy paste sherds were placed in one category rather than into grain texture divisions and are referred to as Goose Creek Plain. 


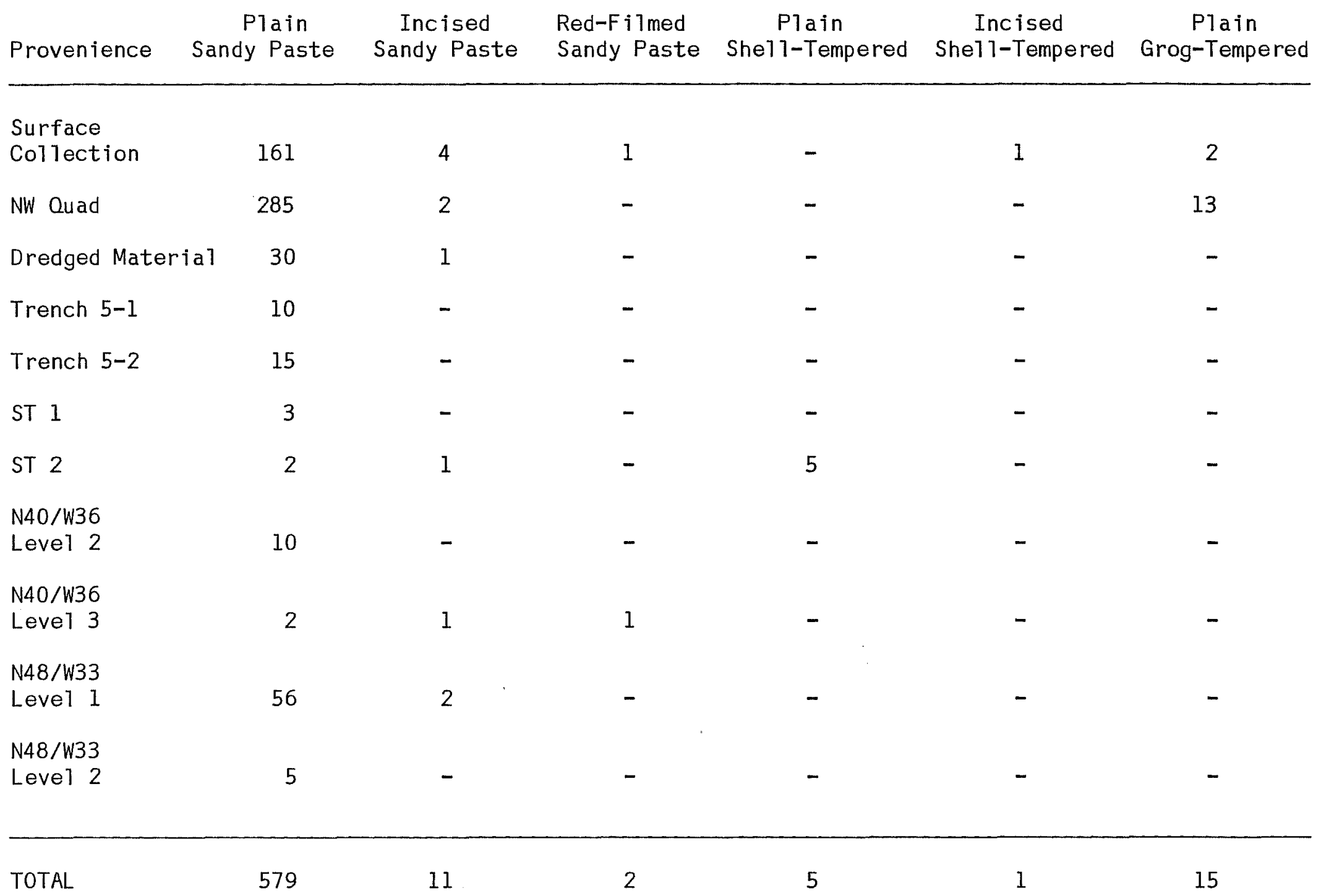



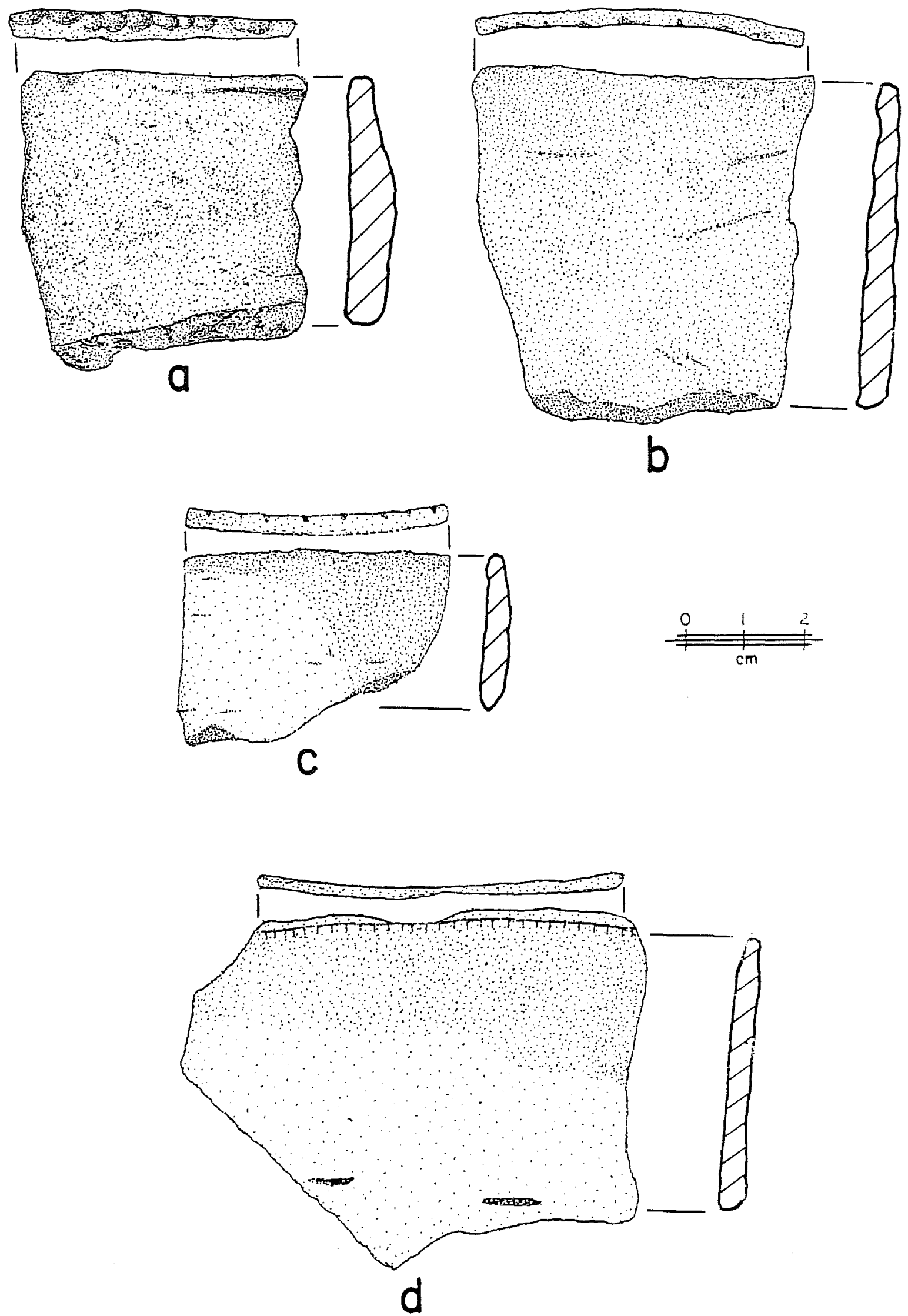

Figure 11. Aboriginal Ceramics from Site 41 HR 39. a, Goose Creek Plain rim sherd with worked $1 \mathrm{ip}$; b, Goose Creek Plain rim sherd with flattened 1 ip and interior 1 ip notching; $c$, Goose Creek Plain rim sherd with flattened 1 ip and interior 1 ip notching; d, Goose Creek Incised rim sherd with tick marks below the thinned $1 \mathrm{ip}$. 

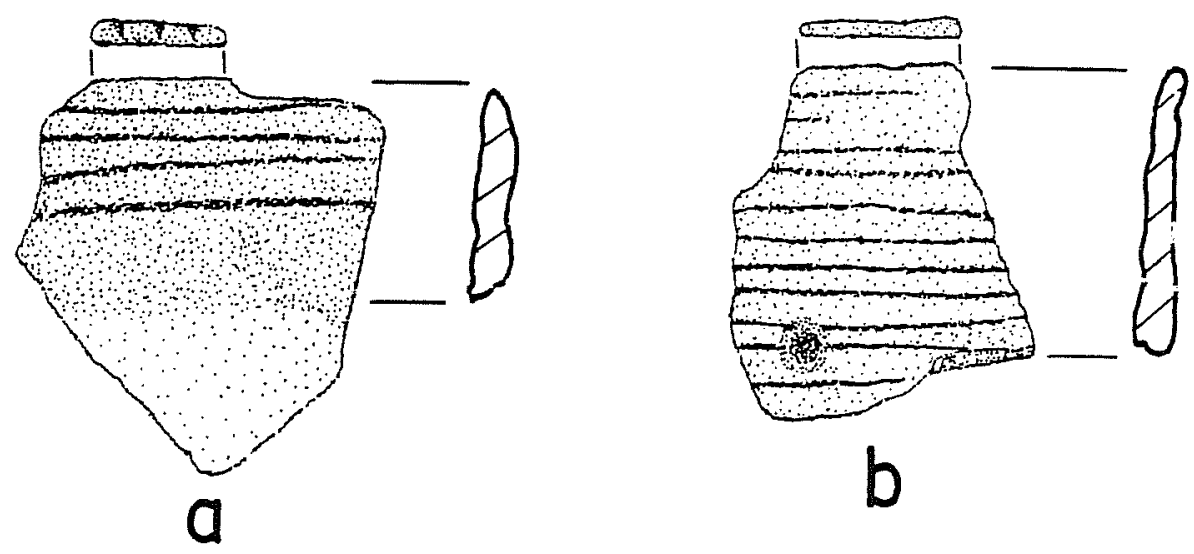

b
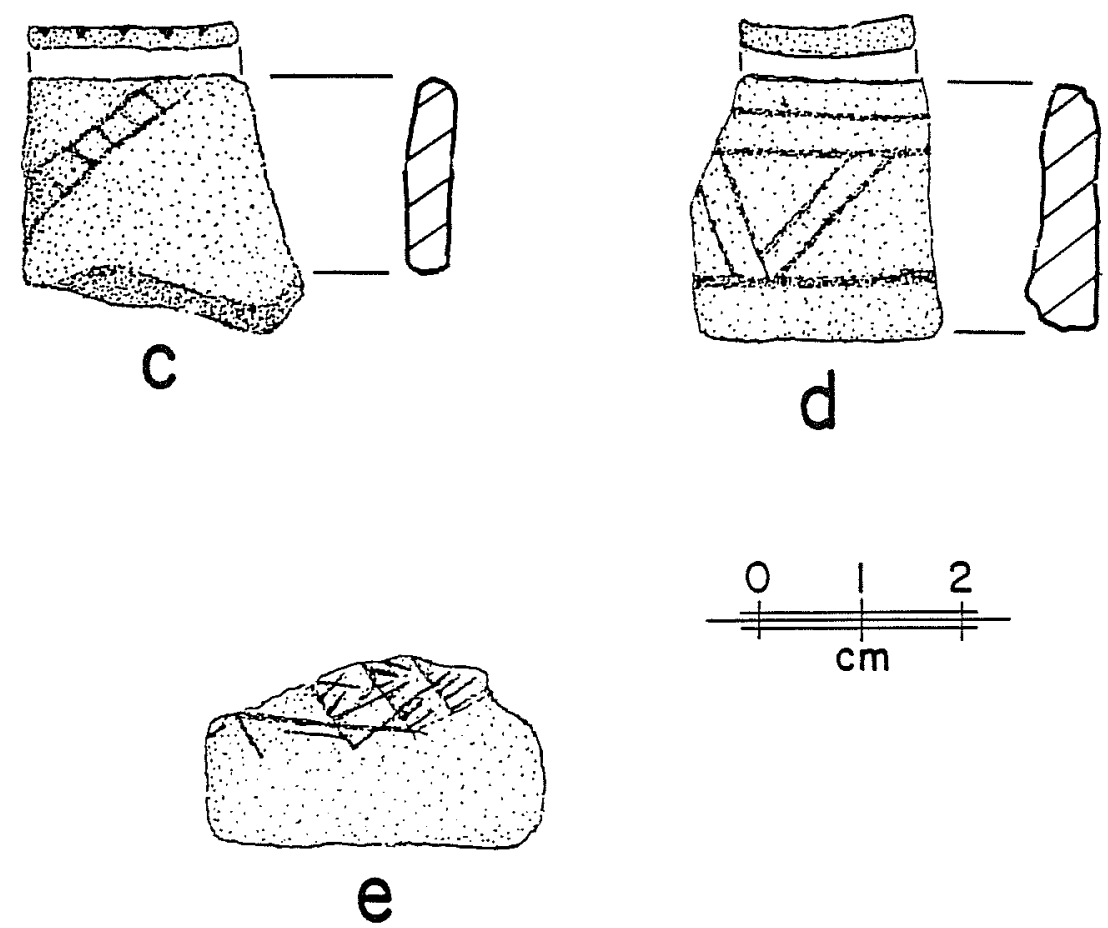

Figure 12. Aboriginal Ceramics from Site 41 HR 39. a, Goose Creek Incised rim sherd with flattened $1 \mathrm{ip}$ and interior $1 \mathrm{ip}$ notching, and horizontal 1 ines beneath the $1 \mathrm{ip}$; $b$, Goose Creek P1ain rim sherd with thinned 1 ip, horizontal 1 ines beneath the $1 \mathrm{ip}$, and a biconical dril1 hole; c, Goose Creek Incised rim sherd with flattened 1 ip and interior 1 ip notching, and diagonal hatched lines extending to the $1 \mathrm{ip}$; d, Goose Creek Incised rim sherd with flattened 1 ip, and horizontal and diagonal 1 ines beneath the 1 ip; e, Goose Creek Incised neck sherd. 

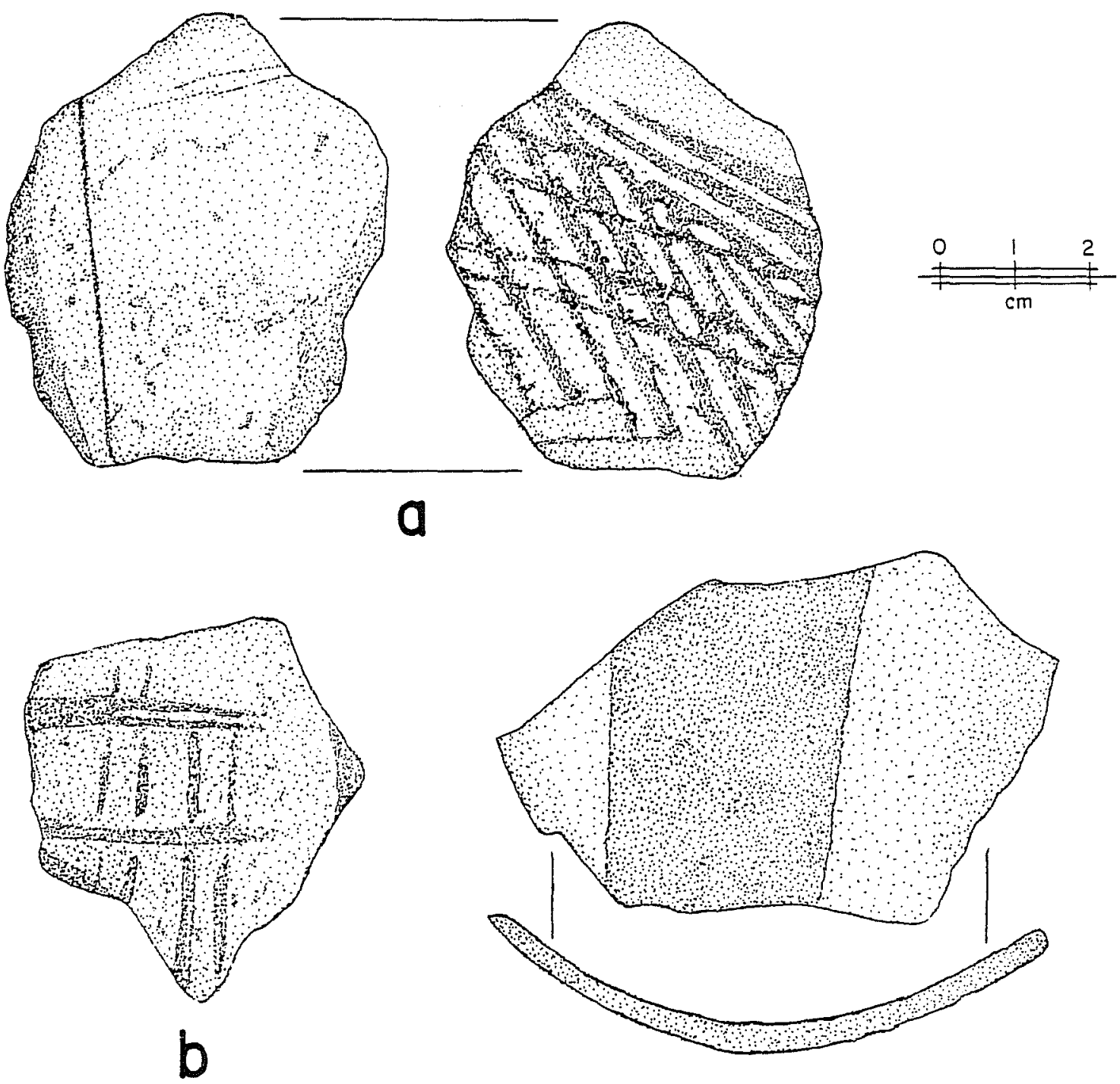

C
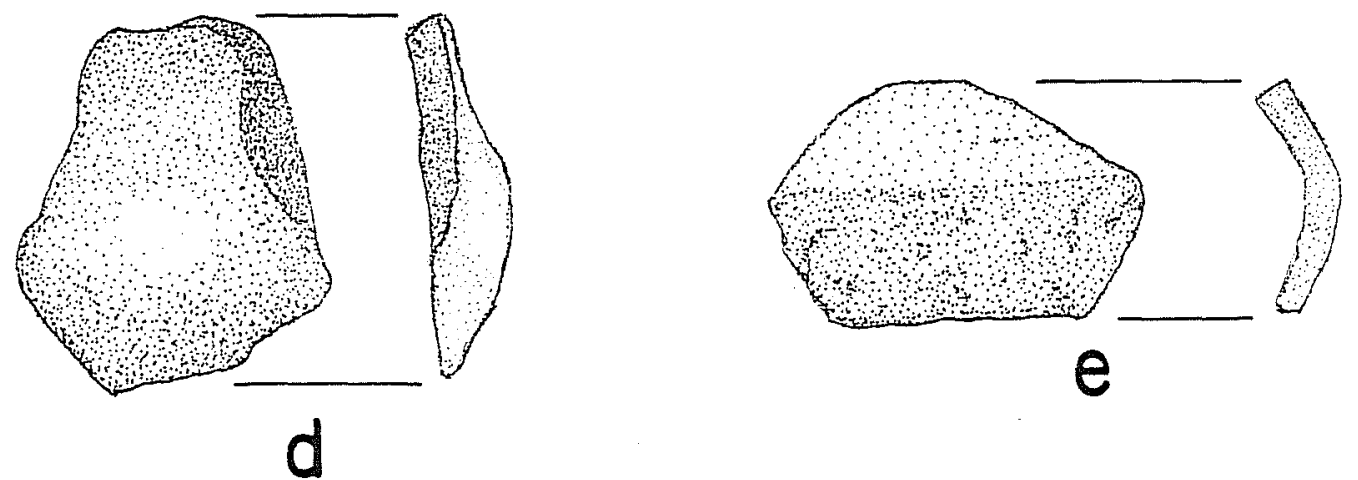

Figure 13. Aboriginal Ceramics from Site 41 HR 39. a, she11-tempered incised body sherd with vertical and horizontal 1 ines and a smoothed, irregular grid on the sherd interior; b, badly eroded Goose Creek Incised body sherd with horizontal and vertical 1 ines; c, banded Goose Creek RedFilmed body sherd; $d$, Goose Creek Plain body sherd with knob; e, grogtempered sherd from vessel shoulder. 
P1ain, sandy paste ceramics, of which there are 579, compose $94.45 \%$ of the sherds recovered from the site. There were $28 \mathrm{rim}, 549$ body, and two base sherds. Of the rim sherds, 24 had thinned $1 \mathrm{ips}$, four had flattened 1 ips, and one had a rounded 1 ip. Most of the sherds were recovered from surface collections from the site, particularly in the northwest quadrant along the northern bluff. In the controlled excavation units, the most sherds came from N48/W33, leve1 1. A 1 esser amount of sherds was recovered from the lower level in both excavation units. Goose Creek Plain ceramics are not particularly time diagnostic since they occur throughout the Ceramic period, from A.D. 100 to A.D. 1800 (Aten $1983 \mathrm{a}: \mathrm{Fig}$. 14.1).

Eleven incised, sandy paste ceramics, known as Goose Creek Incised, were recovered from the site, which composed 1.8\% of the study collection. There were $11 \mathrm{rim}$ sherds of this type, of which two had thinned 1 ips (Figs. 11,d; $12, b)$, and three had flattened 1 ips ( $F$ ig. 12,a,c,d). The 1 ip was broken from six of the sherds. Decoration on these sherds included punctations and incisions, and generally included the following designs: (1) from one to six horizontal paral1el lines underneath which was a single row of punctated dots; (2) lower pendant triangles filled with 1 ines or punctates; (3) diagonal ladders; (4) ticking along border 1 ines; (5) crossed diagonals; (6) ticked diagonals between border 1 ines; (7) diamonds or squares filled with crosshatching; and (8) wavy 1 ines. Since the body and base of these vessels were not decorated, those parts of the incised vessels are necessarity included with the Goose Creek Plain ceramics. The incised rim sherds were predominantly recovered during surface collections, though they were also found in shovel test 1 , in level 3 of unit N40/W36, and in level 1 of unit N48/W33. Goose Creek Incised ceramics occur sporadical1y throughout much of the Ceramic period.

Plain, red-filmed sandy paste sherds, of which there were only two recorded during the analysis, formed $0.3 \%$ of the collection. It is possible that the red $f i 1 \mathrm{~m}$ on some sherds was removed during the water screening or during processing in the laboratory since a greater number of these sherds had been collected during field investigations. Recorded were one red-filmed body sherd (Fig. 13,C) and one base sherd. The base sherd was well fired and was banded with a vertical zone which is unstipped, and sided by two red-filmed vertical zones. The decoration zones are further delineated by sha $110 \mathrm{w}$ grooves along the zone edges. Like the other Goose Creek ceramics, Goose Creek Red-Filmed ceramics occur sporadical ly throughout the Ceramic period.

\section{She 1 1-Tempered Ceramics}

No bone-tempered ceramics were recognized in the sherd sample, though there were six sherds (1.0\% of the collection) which appear to be she 11 tempered (Fig. 13,a). The temper in these sherds appear to have a pearly 1 uster, which would not be expected to be present in bone. There were six body sherds, one of which was incised. Most of the she11-tempered sherds came from shovel test 2, and one (which was incised) was from the general surface collection. The interior of the incised shel1-tempered sherd had a "grid of crossed lines," which may have been produced by smoothing the vessel interior with coarse grass (Suhm, Krieger, and Jelks 1954:378, Plate 71,H), or perhaps with a "ribbed marine she11 tool" (Ca1houn 1961:325). The interior of the 
sherds in the remainder of the study collection had smoother surfaces. Aten (1983a:244-245, Fig. 14.1) did not assign this kind of sherd to any category and states that most she 11 tempering is probably fragmented Rangia or sma 11 gastropod shells which are probably fortuitous inclusions. Shell-tempered ceramics are therefore not used as a basis for analysis on the upper Texas coast.

\section{Grog-Tempered Ceramics}

Grog-tempered ceramic types which occur in the Galveston Bay area are Baytown Plain and San Jacinto Incised (Aten 1983a:239-242, Fig. 14.1). San Jacinto grog-tempered ceramics are thin-walled with moderate amounts of grog fragments in a sandy clay paste. The 15 plain, grog-tempered (one rim sherd and 14 body sherds) sherds compose on 1 y $2.45 \%$ of the study samp $1 e$, but were the second most common ceramic type recovered from the site (Fig. $13, e)$. The rim sherd had a thinned 1 ip. Al1 the grog-tempered sherds were collected from the site surface, predominantly from the northern bluff and beach. Grog-tempered ceramics occur from ca. A.D. 1000 to 1800 (Aten 1983a: Fig. 14.1). Day (1982) reported finding a San Jacinto Plain ceramic sherd at site 41 HR 39, on the northern beach along the $01 d$ River.

\section{Lithics}

The 40 pieces of 1 ithic materials recovered from the site during this project (Table 3; Figs. 14; 15) were predominantly made of a opaque, fine-grained, golden tan, banded chert; a few pieces, however, were of a coarser opaque gray chert, or a translucent brown chert. There were also three smal1 pieces from petrified wood. The appearance of the cortex (the natural surface of flintlike materials; Crabtree 1972:56) remaining on the debitage and worked 1 ithics indicates the utilization of stream cobbles as a 1 ithic source. Six pieces of chert debitage (residual 1 ithic material resulting from too 1 manufacture; ibid.:58) showed signs of thermal a 7 teration as evidenced by reddening and/or crazing and potlids ( 1 ano-convex flakes which leave a concave scar, and result from differential expansion and contraction of the material; Crabtree 1972:84). At least two flakes had blue paint on them, and one lithic tool, a unifacial scraper, had concrete attached to it (Fig. 14,d). Surface scatters of gravels and cobbles, which may have been brought in for construction work, were observed predominantly in the central part of the project area. The Perdiz point recovered and reported by Day (1982) from the northern part of the site along the 01d River was included in Table 3, making a total of 41 reported 1 ithic items from the site.

The debitage was classified into categories which roughly follow the 1 ithic reduction sequence for the hand-held hard-hammer percussion technique (cf. Shafer 1973:63-64). Primary flakes have cortex across the entire dorsa 1 surface. Secondary flakes have cortex on a part of the dorsal surface. Interior flakes have no cortex, except possibly on the striking platform. Thinning flakes have a 1 ipped platform. which indicates they were removed from the edge of a biface. Eragments are broken flakes that could not be confidently assigned to any other category. Shatter includes debitage which is blocky in shape, and may have been produced by the bipolar (anvil) 
TABLE 3. PROVENIENCE OF LITHIC MATERIALS

\begin{tabular}{|c|c|c|c|c|c|c|c|c|}
\hline Provenience & $\begin{array}{l}\text { Primary } \\
\text { Flakes }\end{array}$ & $\begin{array}{l}\text { Secondary } \\
\text { F1 akes }\end{array}$ & $\begin{array}{l}\text { Interior } \\
\text { Flakes }\end{array}$ & $\begin{array}{c}\text { Thinning } \\
\text { Flakes }\end{array}$ & Fragments & Shatter & Other & Crusher \\
\hline $\begin{array}{l}\text { Surface } \\
\text { Collection }\end{array}$ & - & - & 1 & 1 & - & 2 & $\begin{array}{l}\text { Ensor point } \\
\text { Mano fragment }\end{array}$ & 2 \\
\hline NW Quad & - & 1 & 3 & - & - & - & $\begin{array}{l}\text { Perdiz point* } \\
\text { Unifacial scraper } \\
\text { Thin biface fragment }\end{array}$ & 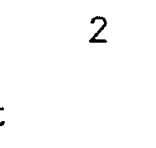 \\
\hline Dredged Material & - & - & - & 1 & 1 & 2 & Type A-1 point & 1 \\
\hline Trench 5-1 & - & 2 & - & - & 2 & - & Thin biface fragment & 1 \\
\hline Trench 5-2 & - & - & - & 1 & - & - & Unifacial scraper & - \\
\hline Shovel Test 1 & - & - & 1 & - & - & - & - & - \\
\hline $\begin{array}{l}\text { N40/W36 } \\
\text { Leve1 } 2\end{array}$ & - & - & - & - & - & - & - & - \\
\hline $\begin{array}{l}\text { N40/W36 } \\
\text { Leve1 } 3\end{array}$ & - & 2 & 1 & 1 & 1 & - & - & - \\
\hline $\begin{array}{l}\text { N48/W33 } \\
\text { Leve1 } 1\end{array}$ & - & 2 & 2 & - & 3 & - & - & - \\
\hline $\begin{array}{l}\text { N48/W33 } \\
\text { Leve1 } 2\end{array}$ & - & - & - & - & - & - & - & - \\
\hline TOTAL & 0 & 7 & 8 & 4 & 7 & 4 & 8 & 6 \\
\hline
\end{tabular}

*Day 1982 

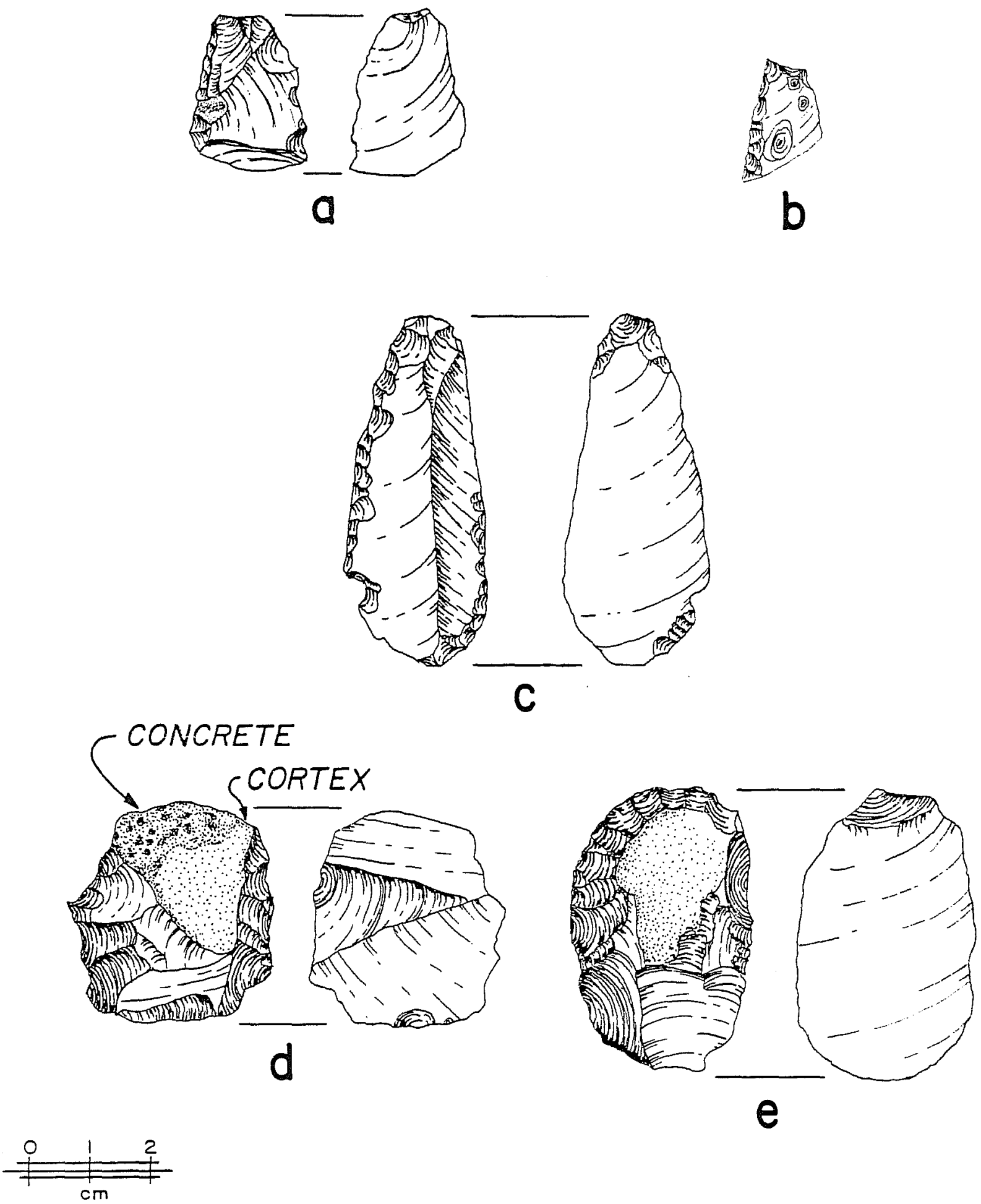

Figure 14. Lithic Artifacts from Site 41 HR 39. a, retouched secondary chert flake with 1 ipped platform; b, thermally altered, very thin chert biface fragment; $c$, utilized, retouched interior chert blade; d, uniface, chert ovoid end scraper with concrete attached; e, uniface, chert ovoid end scraper. 



$b$
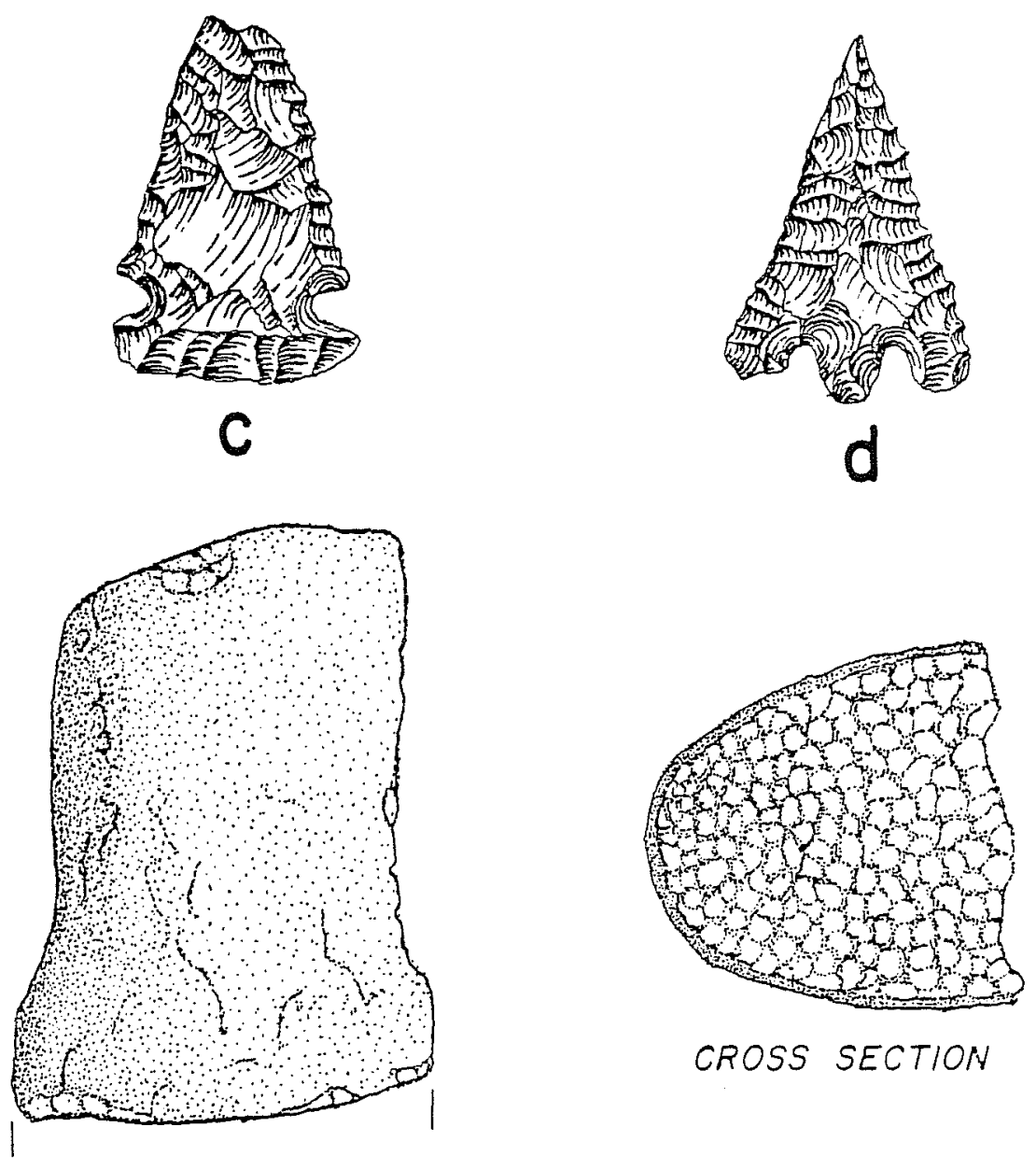

CROSS SECTION

e

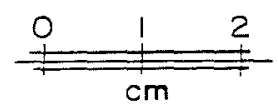

Figure 15. Lithic Artifacts from Site 41 HR 39. a, thin, chert biface fragment; $b$, chert biface fragment; $c$, chert Ensor point; d, chert Type A-1 point; e, quartzite mano fragment. 
percussion technique (cf. Shafer 1973:64-65). The 1ithic artifacts included retouched flakes (cf. Crabtree 1972:89) and unifacial and bifacial tools. With the possible exception of the 1 ithic shatter, the debitage and too 15 from the site general1y appear to have been produced by, or resulted from, the hand-held hard-hammer percussion technique rather than from bipolar percussion. An additional category of 1 ithics from the site, however, includes cobbles and flakes which appear to have been through a gravel crusher.

No primary flakes were recovered from the site. Seven secondary flakes (one of petrified wood) and seven interior flakes were recovered. Also recovered were four thinning flakes, seven 1 ithic fragments, and four pieces of shatter (two of petrified wood). The lack of primary flakes suggests that the initial reduction of 1 ithic materials, such as cobbles, was not done at the site. The secondary and interior flakes indicate that 1 ithic production may have been conducted at the site, and the presence of thinning flakes indicates that tools may have been finished or sharpened there. The 1 ithic shatter consists of smal1 pieces, and may have resulted from bipolar reduction, or possibly from modern activities at the site.

The 1 ithic artifacts consist of a retouched secondary flake (Fig. 14,a) with a 1 ipped platform which terminates in a hinge fracture. An inclusion is on the dorsal side of the $f l a k e$. The flake is retouched on the dorsal side along both edges, and also along approximately half of the distal end. There is a small notch on one side near the distal end of the flake. A thermal1y a 1 tered very thin biface or flake fragment (Fig. 14,b) with a pot 1 id, has bifacial flaking along one edge. One utilized interior blade (Fig. 14,C; cf. Crabtree 1972:42) was retouched along the distal end and one edge on the dorsal side; the retouched side has a notch in it near the distal end of the blade. The two unifaces, ovoid end scrapers (Fig. 14,d,e; cf. Aten 1983a:255, Fig. 13.2), both have cortex on the distal side, and one (Fig. 14,d) has concrete attached to it. There is also a thin biface fragment (Fig. 15,a), and another less finely worked biface fragment (Fig. 15,b) which has a quartz inclusion along the break. The Perdiz point from the site (reported by Day [1982]) is a contracting stem form (Aten 1983a:250, Fig. 13.1, u-aa, citing Suhm and Je1ks 1962:269; cf. Turner and Hester 1985:168). The Ensor point (Fig. 15,c; Turner and Hester 1985:94) is side notched, has a broken tip, and the straight base is beveled on one side; the point is $3.8+\mathrm{cm}$ long, $2.3 \mathrm{~cm}$ wide, and $0.5 \mathrm{~cm}$ thick. The Type A-l point (Fig. 15,d; Aten 1967; cf. Turner and Hester 1985:168) has a sma11 contracting stem, slight 1 y concave serrated edges, and prominent rounded barbs; it is $3.85 \mathrm{~cm}$ long, $2.55 \mathrm{~cm}$ wide, and $0.4 \mathrm{~cm}$ thick. A fragment of a quartzite mano (a smal1, oval handstone used to grind foods) is rounded and unworked on one side, and is flattened with evidence of grinding on the other side (Fig. 15,e; cf. Turner and Hester 1985:248-249).

A1 1 but one of the retouched $f 1$ akes and tools were recovered from the site surface, from the eroding northern bluff of the site along the $01 d$ River, and from the backdirt of backhoe trench 5 (collection stations 5-1 and 5-2). One interior flake was found in shovel test 1 . In unit N40/W36, no 1 ithics were recovered from level 2, but level 3 yielded two secondary flakes, a therma $11 y$ altered interior flake, a thinning flake, and a flake fragment. In level $I$ of unit N48/W33, one chert and one petrified wood secondary f1ake, one 
thermally altered interior flake with a bifacially worked edge, and three flake fragments were recovered; no 1 ithics were found in 1 evel 2 of this unit.

\section{Eaunal Remains}

Most of the faunal remains from site 41 HR 39 were Rangia cuneata shel 15 and shel1 fragments (Tables 4, 5). A few vertebrate faunal remains were collected (Tab1e 6), although some date to the historic occupation of the site. The presence of shel1 roads in the site area and the degree of intermixing of prehistoric and historic materials in the shell midden stratum may suggest that at least part of the shel1s at the site were deposited or introduced during the 1 ater historic utilization of De Zavala Point. A1 1 the invertebrate and vertebrate faunal remains recovered from the 1/4-inch mesh screens are quantified and discussed here. A sample collected from the 1/8inch mesh screens are discussed in the section on the fine screen sample.

With the exception of a few fragments of oyster (Crassostrea virginica), a 11 the identified collected she $11 \mathrm{~s}$ are from the brackish water clam, Rangia cuneata. (Tables 4, 5). The relative amount (by weight) of Rangia shells to oyster she11s in the controlled excavation units ranges from $99.3 \%$ to $99.9 \%$, with oyster shel1s constituting only from $0.1 \%$ to $0.7 \%$ of the samp 1 e.

The Rangia cuneata shel 1 samples from midden context collected during the 1/4-inch mesh screening (Table 4) consist mainly of valves with umbos (58\% by weight). Rangia shel1 fragments without umbos (42\%) form less of the she 1 midden sample. Although none of the Rangia shells or shell fragments recovered from the 1/4-inch screen appear to have been burned, burned she 1 fragments were present in the fine screen sample. No evidence of butchering or human alteration of the shell sample was observed. No evidence was found of barnacles or oyster spats on the she11s, which could yield information on environmental changes in the area. Most of the whole and partial Rangia valves appear weathered.

A seasonality study, or shel 1 growth stage analysis, was done of Rangia cuneata shel is from both levels of the two controlled excavation units at the site (Tables 6, 7). This study, in consultation with Dr. David Carlson of Texas A\&M University, was conducted to determine the season of collection for the shell midden deposits, as was specified in the project contract. The technique employed for such a study was modeled after that described by Aten (1981) and, to a limited extent, after Carison (1983).

The Rangia cuneata shel1s used in the seasonality study came from unit N40/W36, levels 2-3, and also from unit N48/W36, levels 1-2. Shells from both levels in the two controlled excavation units were used to obtain a sufficient sample (50 specimens) of intact specimens of right valves which were 1 arge enough (in the third or fourth year of growth, with shel 1 lengths from 35 to $49 \mathrm{~mm}$ ) to study. Right valves rather than left valves were selected because there were more right valves than left valves in the sample, and the larger sample was considered desirable for this study. The surface of al1 the shel1s are weathered to some extent; most shel 1s are moderately weathered. The archaeologists were advised (David Car1son, personal 
TABLE 4. OUANTIFICATION OF RANGIA CUNEATA SHELLS*

\begin{tabular}{|c|c|c|c|c|c|c|c|}
\hline Provenience & $\begin{array}{l}\text { Total } \\
\text { Weight }\end{array}$ & $\begin{array}{l}\text { Weight of } \\
\text { Valves with } \\
\text { Umbos }\end{array}$ & $\begin{array}{l}\text { Number of } \\
\text { Valves with } \\
\text { Umbos }\end{array}$ & $\begin{array}{l}\text { Weight of } \\
\text { Whole } \\
\text { Valves }\end{array}$ & $\begin{array}{l}\text { Number of } \\
\text { Whole } \\
\text { Valves** }\end{array}$ & $\begin{array}{l}\text { Minimum } \\
\text { Number of } \\
\text { Individuals }\end{array}$ & $\begin{array}{l}\text { Weight of } \\
\text { Fragments } \\
\text { without } \\
\text { Umbos }\end{array}$ \\
\hline $\begin{array}{l}\text { N40/W36 } \\
\text { Level } 2\end{array}$ & 4842.00 & 3139.00 & 408 & 595.00 & $\begin{array}{c}43 \\
\text { (L20/R23) }\end{array}$ & 225 & 1703 \\
\hline $\begin{array}{l}\text { N40/W36 } \\
\text { Leve1 } 3\end{array}$ & 12291.00 & 7463.00 & 1017 & 965.00 & $\begin{array}{c}69 \\
\text { (L33/R36) }\end{array}$ & 521 & 4828 \\
\hline $\begin{array}{l}\text { N48/W33 } \\
\text { Leve1 } 1\end{array}$ & 8058.00 & 4108.00 & 674 & 941.00 & $\begin{array}{c}68 \\
\text { (L34/R34) }\end{array}$ & 337 & 3950 \\
\hline $\begin{array}{l}\text { N48/W33 } \\
\text { Level } 2\end{array}$ & 1857.25 & 1073.25 & 162 & 476.75 & $\begin{array}{c}39 \\
\text { (L14/R25) }\end{array}$ & 87 & 784 \\
\hline TOTAL & 27048.25 & 15783.25 & 2261 & 2977.75 & $\begin{array}{c}219 \\
(\mathrm{~L} 101 / \mathrm{R} 118)\end{array}$ & 1170 & 11265 \\
\hline
\end{tabular}

Note: A11 weights are in grams.

* Only the Rangia cuneata shel1s recovered from the $1 / 4-$ inch mesh screening are included in this table. The Rangia cuneata shel1 fragments recovered from the 1/8-inch mesh water screening are not included.

* The number of whole valves was reduced by shell breakage during excavation.

The number of 1 eft and right whole Rangia cuneata valves is given in parentheses beneath the total number of whole valves. 
TABLE 5. QUANTIFICATION OF NON-RANGIA CUNEATA SHELLS

(CRASSOSTREA VIRGINICA)

Provenience Total Weight $(\mathrm{g})$

$\begin{array}{ll}\text { N40/W36 } & \\ \text { Leve1 2 } & 6 \\ \text { N40/W36 } \\ \text { Leve1 3 } \\ \text { N48/W33 } \\ \text { Leve1 1 } \\ \text { N48/W33 } \\ \text { Leve1 2 }\end{array}$

communication 1985) that it would be best if the more weathered shel 1s were eliminated from the sample, but doing so would result in too small a sample. The weathered shel1s are therefore included in the sample. Carlson (personal communication 1985) explained that the indeterminate category used by Aten (1981) includes valves which have numerous growth interruption rings, and for which no definite annual growth rings could be determined rather than including shel $1 \mathrm{~s}$ for which growth rings could not be distinguished due to weathering. Aten discarded eroded shel $1 \mathrm{~s}$ from his study sample. Annual growth increments were recorded for each selected specimen. The growth stages of specimens (interrupted, early, middle, and late), or a category of indeterminate or uncertain specimens, were also identified.

The results of the shel1 sorting are shown in Table 6. Carlson (1983) analyzed the results using a computer program, and the sample results were found to match reasonably well with the expected proportions for a late May collection (Table 7). Carlson's (1983:22) analysis of 59 reported samples of Rangia shel1s from aboriginal sites indicated that over half the samples had been collected from late April through late May.

Vertebrate faunal remains from the site (Tab 1e 8) were analyzed by Robert F. Scott IV. Fish types represented in the site collection are unidentified fish, gar (Lepisosteus sp.), and croaker or b 1 ack drum (family Sciaenidae). Reptiles in the collection are unidentified turtle and alligator (Alligator missippiensis). Only one bird bone was identified in the collection. Mammals represented in the collection are unidentified large mammal, canid-possibly dog (family Canidae), white-tailed deer (Odocoileus virginianus), domestic cow (Bos sp.), and possibly buffalo (Bison bison). 
TABLE 6. RANGIA CUNEATA GROWTH STAGE EVALUATIONS

\begin{tabular}{lccccc} 
Provenience & Interrupted & Early & Middle & Late & $\begin{array}{r}\text { Uncertain/ } \\
\text { Indeterminate }\end{array}$ \\
\hline $\begin{array}{l}\text { N40/W36 } \\
\text { Leve1 2 }\end{array}$ & 2 & 5 & 3 & - & - \\
$\begin{array}{l}\text { N40/W36 } \\
\text { Leve1 3 }\end{array}$ & 2 & 5 & 7 & 1 & - \\
$\begin{array}{l}\text { N48/W33 } \\
\text { Leve1 1 }\end{array}$ & - & 4 & 8 & 2 & 1 \\
$\begin{array}{l}\text { N48/W33 } \\
\text { Leve1 2 }\end{array}$ & - & 3 & 7 & - & - \\
\hline TOTAL & 4 & 17 & 25 & 3 & 1
\end{tabular}

Note: Only right valves were used for this study.

TABLE 7. COMPARISON OF OBSERVED AND EXPECTED RANGIA CUNEATA GROWTH STAGE PROPORTIONS

\begin{tabular}{lccccc} 
Provenience & Interrupted & Early & Middle & Late & $\begin{array}{r}\text { Uncertain/ } \\
\text { Indeterminate }\end{array}$ \\
\hline $\begin{array}{l}\text { Observed } \\
\text { Proportions }\end{array}$ & 0.080 & 0.340 & 0.500 & 0.060 & 0.020 \\
$\begin{array}{l}\text { Expected } \\
\text { Late May }\end{array}$ & & & & & \\
Proportions* & 0.0451 & 0.3012 & 0.4378 & 0.1236 & 0.0923
\end{tabular}

The mean squared error for the sample is 0.365676 with a variance of 0.049377 .

The error sum of squares for the sample is 0.010637 .

*From Carlson $(1983: 10)$ 
TABLE 8. QUANTIFICATION OF VERTEBRATE FAUNAL REMAINS

\begin{tabular}{|c|c|c|c|c|}
\hline Provenience & Element & Age & Anima 1 & Comments \\
\hline \multirow[t]{6}{*}{$\begin{array}{l}\text { Surface } \\
\text { Collection }\end{array}$} & $\begin{array}{l}\text { long bone } \\
\text { fragment }\end{array}$ & - & large mammal & $\begin{array}{l}\text { water-rolled; some } \\
\text { trace of a green } \\
\text { snap fracture; not } \\
\text { a tool }\end{array}$ \\
\hline & $\begin{array}{l}\text { right medial } \\
\text { calcaneus }\end{array}$ & mature & white-tailed deer & fragment \\
\hline & $\begin{array}{l}\text { distal } \\
\text { metapodial }\end{array}$ & $?$ & white-tailed deer & $\begin{array}{l}2 \text { articular facets; } \\
\text { badly eroded }\end{array}$ \\
\hline & $\begin{array}{l}\text { right astragalus } \\
\text { fragment }\end{array}$ & $?$ & Bos/Bison & \\
\hline & $\begin{array}{l}\text { medial } \\
\text { metapodial }\end{array}$ & $?$ & white-tailed deer & fragment \\
\hline & $\begin{array}{l}\text { long bone } \\
\text { fragment }\end{array}$ & - & mammal & \\
\hline \multirow[t]{5}{*}{ NW Quad } & $\begin{array}{l}\text { long bone } \\
\text { fragment }\end{array}$ & - & $\begin{array}{l}\text { no identifi- } \\
\text { cation possible }\end{array}$ & \\
\hline & $\begin{array}{l}\text { long bone } \\
\text { fragment }\end{array}$ & - & $\begin{array}{l}\text { no identifi- } \\
\text { cation possible }\end{array}$ & burned \\
\hline & $\begin{array}{l}\text { long bone } \\
\text { fragment }\end{array}$ & mature & $\begin{array}{l}\text { no identifi- } \\
\text { cation possible }\end{array}$ & \\
\hline & $\begin{array}{l}\text { left proximal } \\
\text { radius }\end{array}$ & mature & B. bison & $\begin{array}{l}\text { numerous cut marks } \\
\text { on the proximal } \\
\text { anterior; possible } \\
\text { marrow fractures }\end{array}$ \\
\hline & $\begin{array}{l}\text { lower } 1 \mathrm{imb} \\
\text { fragment }\end{array}$ & mature & large mammal & $\begin{array}{l}\text { water-worn and } \\
\text { mineralized }\end{array}$ \\
\hline $\begin{array}{l}\text { Dredged } \\
\text { Material } \\
\end{array}$ & large rib facet & mature & large mammal & 2 fragments fit \\
\hline \multirow[t]{4}{*}{ Trench 4-3 } & $\begin{array}{l}5 \text { long bone } \\
\text { fragments }\end{array}$ & - & large mammal & \\
\hline & $\begin{array}{l}\text { right } \\
\text { centroquartal }\end{array}$ & mature & white-tailed deer & fragment \\
\hline & $\begin{array}{l}3 \text { plastron } \\
\text { fragments }\end{array}$ & - & turtle & \\
\hline & I fragment & - & $\begin{array}{l}\text { no identifi- } \\
\text { cation possible }\end{array}$ & \\
\hline
\end{tabular}


TABLE 8. (continued)

\begin{tabular}{|c|c|c|c|c|}
\hline Provenience & Element & Age & Anima 7 & Comments \\
\hline \multirow[t]{5}{*}{ Trench 5-1 } & $\begin{array}{l}\text { right distal } \\
\text { tibia }\end{array}$ & $\begin{array}{l}\text { mature/ } \\
\text { immature }\end{array}$ & white-tailed deer & $\begin{array}{l}\text { incomplete } \\
\text { epiphyseal union }\end{array}$ \\
\hline & $\begin{array}{l}\text { (?)distal } \\
\text { metapodial }\end{array}$ & immature & white-tailed deer & $\begin{array}{l}\text { immature articular } \\
\text { facets }\end{array}$ \\
\hline & 1ong bone fragment & $t-$ & large mamma 1 & \\
\hline & dentary & - & fish & $\begin{array}{l}\text { garlike; too little } \\
\text { to identify }\end{array}$ \\
\hline & 7 fragments & - & $\begin{array}{l}\text { no identifi- } \\
\text { cation possible }\end{array}$ & I burned brown \\
\hline \multirow[t]{12}{*}{ Trench 5-2 } & 21 fragments & - & $\begin{array}{l}\text { no identifi- } \\
\text { cation possible }\end{array}$ & \\
\hline & I fragment & - & $\begin{array}{l}\text { no identifi- } \\
\text { cation possible }\end{array}$ & gnaw marks \\
\hline & 1 fragment & - & $\begin{array}{l}\text { no identifi- } \\
\text { cation possible }\end{array}$ & snap fracture \\
\hline & $\begin{array}{l}5 \text { long bone } \\
\text { fragments }\end{array}$ & - & $\begin{array}{l}\text { no identifi- } \\
\text { cation possible }\end{array}$ & 1 with cut marks \\
\hline & $\begin{array}{l}3 \text { flat long } \\
\text { bone fragments }\end{array}$ & - & $\begin{array}{l}\text { no identifi- } \\
\text { cation possible }\end{array}$ & \\
\hline & $\begin{array}{l}\text { long bone } \\
\text { fragment }\end{array}$ & - & large mammal & burned brown \\
\hline & $\begin{array}{l}\text { long bone } \\
\text { fragment }\end{array}$ & - & mamma 1 & $\begin{array}{l}\text { snap fracture; } \\
\text { made into an aw1 }\end{array}$ \\
\hline & proximal femur & mature & $\begin{array}{l}\text { white-tailed } \\
\text { deer(?) }\end{array}$ & fragment \\
\hline & left astragalus & mature & white-tailed deer & \\
\hline & $\begin{array}{l}\text { left scapula } \\
\text { fragment }\end{array}$ & mature & white-tailed deer & glenoid portion \\
\hline & $\begin{array}{l}\text { pelvis/left } \\
\text { acetabulum }\end{array}$ & mature & Bos & $\begin{array}{l}\text { saw cut through } \\
\text { ischium; blunt } \\
\text { fracture near } \\
\text { socket }\end{array}$ \\
\hline & $\begin{array}{l}\text { vertebra } \\
\text { centrum }\end{array}$ & sma11 & alligator & burned brown \\
\hline
\end{tabular}


TABLE 8. (continued)

\begin{tabular}{|c|c|c|c|c|}
\hline Provenience & Element & Age & Animal & Comments \\
\hline \multirow[t]{6}{*}{$\begin{array}{l}\text { Trench } 5-2 \\
\text { (continued) }\end{array}$} & dorsal spine & - & $\begin{array}{l}\text { family } \\
\text { Sciaenidae }\end{array}$ & $\begin{array}{l}\text { either black drum } \\
\text { or Atlantic croaker }\end{array}$ \\
\hline & neural spine & - & fish & $\begin{array}{l}\text { incised; bead } \\
\text { blank(?) }\end{array}$ \\
\hline & 6 scales & - & $\operatorname{gar}(f i s h)$ & \\
\hline & sku11 element & - & $\begin{array}{l}\text { fish; no identifi- } \\
\text { cation possible }\end{array}$ & \\
\hline & 5 fragments & - & $\begin{array}{l}\text { fish; no } \\
\text { identification } \\
\text { possible }\end{array}$ & \\
\hline & premaxi11a & - & $\begin{array}{l}\text { fish; no } \\
\text { identification } \\
\text { possible }\end{array}$ & not gar or drum \\
\hline
\end{tabular}

2 vertebrae large-size family Sciaenidae

1 plastron - turtle

fragment

\begin{tabular}{|c|c|c|c|c|}
\hline \multirow[t]{5}{*}{$\begin{array}{l}\text { N40/W36 } \\
\text { Leve1 } 2\end{array}$} & $\begin{array}{l}3 \text { long bone } \\
\text { fragments }\end{array}$ & - & large mammal & $\begin{array}{l}\text { badly eroded; } \\
\text { snap fractured }\end{array}$ \\
\hline & $\begin{array}{l}\text { I long bone } \\
\text { fragment }\end{array}$ & $?$ & white-tailed deer & $\begin{array}{l}\text { metapodial } \\
\text { fragment(?) }\end{array}$ \\
\hline & $\begin{array}{l}1 \text { metapodial } \\
\text { fragment (?) }\end{array}$ & mature & $\begin{array}{l}\text { white-tailed } \\
\text { deer(?) }\end{array}$ & \\
\hline & 34 fragments & - & $\begin{array}{l}\text { no identifi- } \\
\text { cation possible }\end{array}$ & \\
\hline & 1 fragment & - & $\begin{array}{l}\text { fish; no identifi- } \\
\text { cation possible }\end{array}$ & \\
\hline \multirow[t]{4}{*}{$\begin{array}{l}\text { N40/W36 } \\
\text { Level } 3\end{array}$} & $\begin{array}{l}2 \text { long bone } \\
\text { fragments }\end{array}$ & - & 1arge mamma 1 & $\begin{array}{l}\text { negative impacts; } \\
\text { green snap } \\
\text { fractures }\end{array}$ \\
\hline & $\begin{array}{l}9 \text { long bone } \\
\text { fragments }\end{array}$ & - & $\begin{array}{l}\text { no identifi- } \\
\text { cation possible }\end{array}$ & \\
\hline & 42 fragments & - & $\begin{array}{l}\text { no identifi- } \\
\text { cation possible }\end{array}$ & \\
\hline & $\begin{array}{l}\text { I long bone } \\
\text { fragment }\end{array}$ & - & large mammal & \\
\hline
\end{tabular}


TABLE 8. (continued)

\begin{tabular}{|c|c|c|c|c|}
\hline Provenience & Element & Age & Animal & Comments \\
\hline \multirow[t]{10}{*}{$\begin{array}{l}\text { N48/W33 } \\
\text { Level } 1\end{array}$} & premolar & $\begin{array}{l}\text { mature/ } \\
\text { immature }\end{array}$ & $\begin{array}{l}\text { family } \\
\text { Canidae }\end{array}$ & $\begin{array}{l}\text { upper right fourth } \\
\text { premolar fragment; } \\
\text { probably domestic } \\
\text { dog }\end{array}$ \\
\hline & 2 scales & - & gar & \\
\hline & $\begin{array}{l}\text { complete } \\
\text { dentary }\end{array}$ & medium-size & gar & 2 fragments \\
\hline & 4 neural spines & - & family Sciaenidae & \\
\hline & vertebra & - & fish & badly eroded \\
\hline & pectoral spine & - & fish & fragment \\
\hline & 3 fragments & - & $\begin{array}{l}\text { fish; no } \\
\text { identification } \\
\text { possible }\end{array}$ & \\
\hline & vertebra & medium-size & turtie & badly eroded \\
\hline & $\begin{array}{l}11 \text { long bone } \\
\text { fragments }\end{array}$ & - & large mammal & \\
\hline & 19 fragments & - & $\begin{array}{l}\text { no identifi- } \\
\text { cation possible }\end{array}$ & 1 burned \\
\hline \multirow[t]{5}{*}{$\begin{array}{l}\text { N48/W33 } \\
\text { Level } 2\end{array}$} & $\begin{array}{l}\text { right } \\
\text { astragulus(?) } \\
\text { fragment }\end{array}$ & mature & white-tailed deer & badly eroded \\
\hline & long bone & - & bird & \\
\hline & 1 fragment & - & large mammal & very thick fragment \\
\hline & I fragment & - & $\begin{array}{l}\text { no identifi- } \\
\text { cation possible }\end{array}$ & \\
\hline & 1 fragment & - & $\begin{array}{l}\text { no identifi- } \\
\text { cation possible }\end{array}$ & burned black \\
\hline
\end{tabular}


The faunal material recovered during excavations at 41 HR 39 generally resembles a prehistoric assemblage. Many of the bones show evidence of water-rolling or prolonged surface exposure. Several fragments appear to be mineralized. The only definitely historic bone, from a cow (Bos), is a pelvis fragment with a clear saw mark recovered from backhoe trench 5-2. No other collection unit could definitely be said to contain historic remains. Final1y, enough indications of prehistoric butchering (blunt impact fractures and green snap fractures) exist to confidently group most of the bone as being derived from prehistoric deposits.

Material from the surface collection bags contained mostly white-tailed deer remains, some of which shows evidence of having been marrow fractured. Though this trait does not guarantee a prehistoric origin for the bone, it would be unusual to find similar marks on a bone butchered with historic tools. One astragalus fragment in this collection could represent a domestic cow (Bos). However, a large part of a radius exhibiting clear cut marks on its anterior surface is tentatively determined to be Bison bison based on the similarity of cut marks to those made by stone tools. It was recovered in the northwest quadrant (from the she 11 midden deposits along the northern bluff of the site) along with a large, thick, unidentified bone fragment that was partially mineralized. General1y, it can be said that the surface collection, including the northwest quadrant, had bone derived from a prehistoric context with the possibility of some historic mixing.

Col1ections from backhoe trench 4, collection area 3 (trench 4-3) yielded evidence of white-tailed deer and an unidentified turtle. Most of the bone fragments in trench 4-3 are long bone fragments, probably a deer or similarsized mammal. Backhoe trench 5-1 was similar, except the white-tailed deer fragments are of an immature animal less than 12 months $01 d$ (Gilbert 1980:102). One fragment of fish bone found in trench 5-1 could not be accurately identified.

Backhoe trench 5-2 yielded the largest amount of bone. Al1 igator, whitetailed deer, turtle, gar, and Atlantic croaker (or a similar fish of the family Sciaenidae) were a 11 represented in the total backhoe trench 5-2 collection. Gar is represented by scales, the most durable of their skeletal elements, and portions of their dentaries. Neural vertebrae spines and some skul 1 elements representing a marine Sciaenid fish strongly resemble At 1 antic croaker (Micropogon undulatus) or black drum (Pogonias cromis). Both are common in estuaries in al1 but cold weather and can exceed $50 \mathrm{~cm}$ in size. The al1igator, represented by a sma11, immature vertebral centrum, was once common in coastal marshes and estuaries. The centrum had been burned. The on $1 \mathrm{y}$ two pieces of worked bone observed in the collection were both from trench 5-2. One is a long bone fragment from a mammal, with a snap fracture and made into a sma 11 aw 1 ; the other is an incised neural spine of a fish which may have been a bead blank.

Collections from the controlled excavation units were generally smal 1 except for N48/W33, leve1 1. Fragments of bones represent a canid, gar, Sciaenid fish, turtle, and an unidentified large mammal from level 1 of N48/W33. The canid, probably a dog, is represented by a part of the fourth premolar which indicates an age of 1 ess than 12 months. Several fish bones which could not 
be identified further were also present. White-tailed deer was definitely identified in N48/W33, leve 1 2; the on 1 y bird bone from the site came from this level, but could not be identified any further. Several fragments from the excavation units showed evidence of exposure to deteriorating elements, either water-rolling or drying and cracking.

In general, the collection is unremarkable for a prehistoric site in Texas. However, the occurrence of bison, white-tailed deer, alligator, gar, and a Sciaenid fish together is somewhat unusual. Such a collection indicates exploitation of habitats ranging from grassland for the bison, mixed woodland and grassland for the browsing white-tailed deer, marshes for the alligator, fresh and brackish water for the gar, and brackish and marine water for the Sciaenids. Obviously the inhabitants of 41 HR 39 were not highly specialized in their foraging strategies, but were skilled in a number of methods of procuring food animals. A similar assemblage of animals was identified at a series of she 11 middens near Clear Lake in Galveston and Harris Counties (Scott 1984:185-202). Similar sites may indicate that she11 middens were not nearly as specialized, but were actually a part of a very broad subsistence base.

\section{Eine Screen Sample}

A11 the materials recovered from the 1/8-inch hardware mesh screen were kept since subsistence and technological data can be recovered from such samples (Aten 1983a:170; Fields and Jackson 1984:20). One fine screen samp 1e, the lower level (3) of the shel1 midden deposit in unit N40/W36, was separated and briefly examined (Table 9) to investigate the potential of the remainder of the fine screen materials. This particular sample was chosen because it appeared to contain less modern organic material, such as bark and rootlets, than the other samples and therefore might be somewhat less disturbed. A150, as the sample was from the lower stratum of the unit, it might be less disturbed from recent activities than the upper stratum which was in contact with dredged material.

Referring to Table 9, the analysis of the fine-screened sample consists predominantly of fractured unburned Rangia cuneata shel 1s (77\% of the total weight). A smaller percentage (11\%) of the fractured Rangia shells appears to have been burned. These burned shel1 fragments have streaks of gray and are general1y rounded, unlike the unburned she $11 \mathrm{~s}$ which are usually more angular and white in color. The rounded, weathered appearance of these fragments is thought by Aten (1983b:86) to result "from their extreme softness once subjected to heat either in the process of being opened to extract the clam, or when used as a refractive base for a later hearth." Non-Rangia she 11 fragments, which were unidentified as to type, compose only a small percentage of the sample ( $1 \%$ ).

In the fine screen sample there were numerous iron-manganese concretions, small gravels, small hard clay pieces, and modern organic material such as bark, rootlets, and hackberry seeds. Bone fragments were unidentifiable as to type, and no fish vertebrae or scales were observed. Weathered bits of prehistoric sherds were also identified. Additionally, there was historic material such as weathered fired brick fragments, glass fragments, plastic 
TABLE 9. QUANTIFICATION OF FINE SCREEN SAMPLES BY WEIGHT

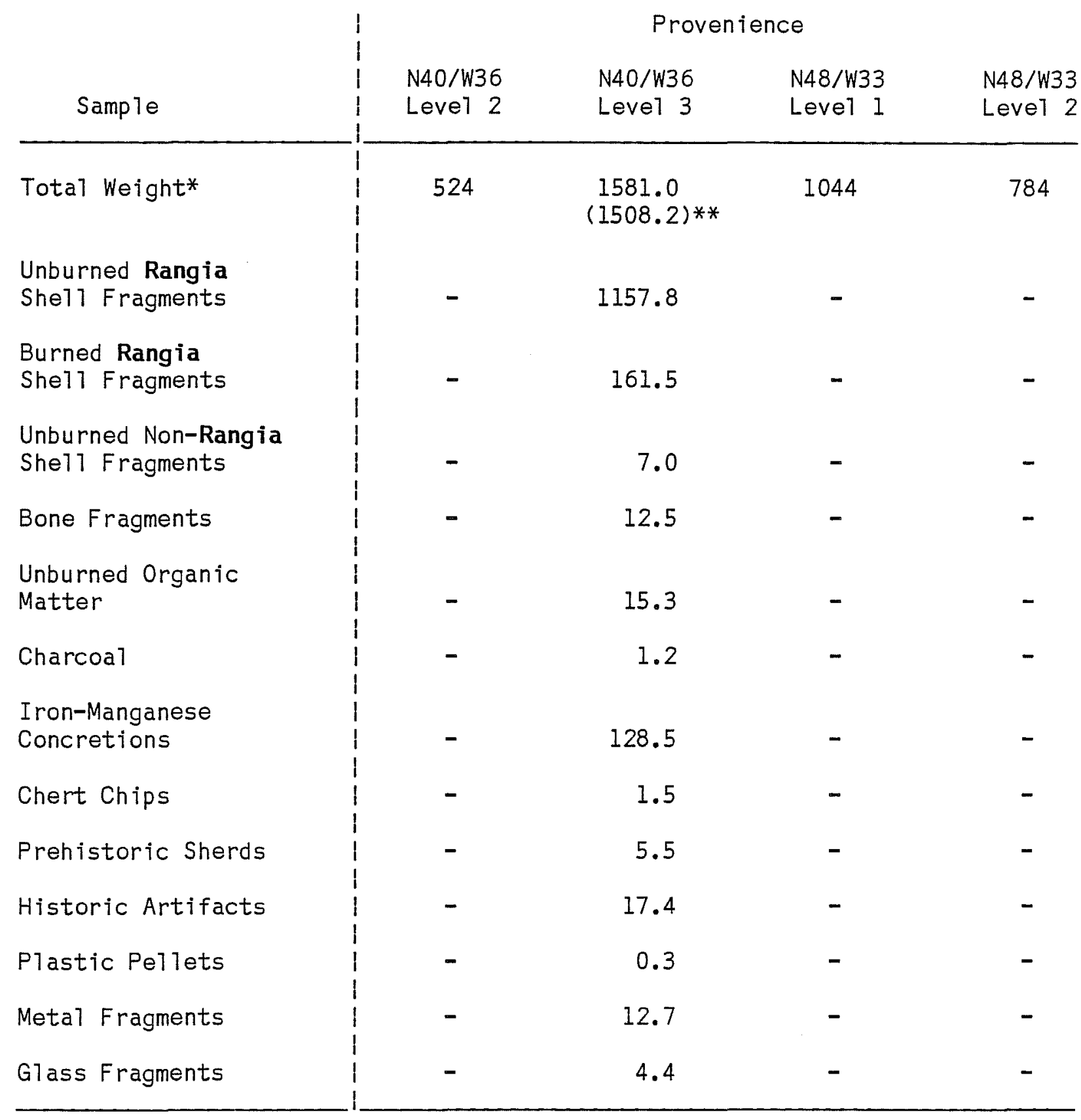

Note: A11 weights are in grams.

*Total weight for a 11 fine screen samples = $3933 \mathrm{~g}$.

**The weight of the fine screen sample after sorting is given in parentheses; the difference in weight $(72.8 \mathrm{~g})$ is due to additional soil loss during sorting. 
pellets, styrofoam, and rusted metal fragments. Charcoal from the sample may be from either the prehistoric or historic component.

\section{HISTORIC MATERIALS}

The historic materials within the general surface collection include several artifacts collected from the site by James Bradley, an employee of the $01 d$ River Fleet and Shipyard, a few materials collected by the staff of the Texas Historical Commission, and numerous items collected from the site during the currently reported project. The historic materials are ceramics, glass, brick, metal, plastic, concrete, coal, plaster, unburned organic material, burned clay, bone, and sandstone fragments (Table 10). Many of these materials were deposited at the site during construction activities since 1980, also previously, when De Zavala Point was used as a local trash dump, and as an Ordnance Depot.

The amount of historic materials recovered from the shell midden deposits in the two controlled excavation units (Table 10) is thought to be indicative of the degree of disturbance present at the site. Bone fragments, which could be either prehistoric or historic, were found in both levels of the two units. Glass, metal, concrete, coal, and plaster were also found in the two levels of both units. Historic ceramics occurred in small amounts, but were present in the lower levels of both units; one historic sherd was found at the contact zone between the she1 $1 \mathrm{midden}$ deposit and the underlying clay subsoil in unit N48/W33, level 2. Several pieces of glass were found in the units at both levels. Brick was recovered from level 3 in unit N40/W36, and from level 1 in unit N48/W33. Unburned organic material such as tree roots and rootlets, hackberry seeds, and fragments of 1 umber, were found in levels 2 and 3 of unit N40/W36, and level l of unit N48/W33. Judging from the count of historic materials in the unit levels, level 1 of unit N48/W33 appears to be the most severely disturbed. Level 3 in unit N40/W36 also had several historic items and the least disturbed levels appear to be 1 evel 2 of unit N40/W36, and level 2 of unit N48/W33. The high level of disturbance in unit N48/W33, level 1, might be explained by its proximity to the surface, which would have been more exposed to dredged materials and modern activities at the site; the lesser amount of historic materials in level 2 of unit N40/W36 and the greater amount in the underlying level 3 of that same unit, however, cannot be explained in the same manner. It is possible that the presence of the greater amount of historic materials in the lower part of the shel1 midden deposit indicates that the aboriginal site deposits have been thoroughly disturbed during historic times, either through natural bioturbation, plowing, dredging, and/or construction activities.

\section{Ceramics}

Eighty-three historic ceramic sherds were collected from the site, of which 45 are earthenware, 25 are stoneware, and 13 are porcelain. The historic ceramics and glass from the site were identified by Anne Fox of the CAR-UTSA. 
TABLE 10. PROVENIENCE OF HISTORIC MATERIALS: GENERAL CATEGORIES

\begin{tabular}{|c|c|c|c|c|c|c|c|c|c|c|}
\hline Provenience & Ceramics & G1ass & Brick & Metal & Plastic & $\begin{array}{l}\text { Concrete, } \\
\text { Coal, and } \\
\text { Plaster }\end{array}$ & $\begin{array}{l}\text { Unburned } \\
\text { Organic } \\
\text { Material }\end{array}$ & $\begin{array}{l}\text { Bone } \\
\text { Fragments }\end{array}$ & $\begin{array}{l}\text { Sandstone } \\
\text { Fragments }\end{array}$ & $\begin{array}{l}\text { Burned } \\
\text { Clay }\end{array}$ \\
\hline \multicolumn{11}{|l|}{ Surface } \\
\hline Collection & 52 & 32 & 3 & 1 & - & 4 & - & $x$ & 7 & - \\
\hline NW Quad & 7 & 3 & 7 & 1 & - & 10 & - & $x$ & - & 11 \\
\hline Dredged Material & 9 & - & 1 & - & 2 & - & - & $x$ & - & - \\
\hline Trench 5-1 & 1 & 13 & 3 & 11 & - & - & - & $x$ & - & 5 \\
\hline Trench 5-2 & 8 & 5 & 3 & $8(1) *$ & - & 119 & - & $x$ & - & - \\
\hline \multicolumn{11}{|l|}{ N40/W36 } \\
\hline Level 2 & - & 10 & - & 21 & 8 & 28 & $x$ & $x$ & - & - \\
\hline \multicolumn{11}{|l|}{ N40/W36 } \\
\hline Level 3 & 1 & 35 & 1 & 31 & 2 & 71 & $x$ & $x$ & - & - \\
\hline \multicolumn{11}{|l|}{ N48/W33 } \\
\hline Level 1 & 3 & 79 & 3 & $128(1) *$ & 20 & 204 & $x$ & $x$ & - & - \\
\hline \multicolumn{11}{|l|}{ N48/W33 } \\
\hline Level 2 & 2 & 17 & - & 6 & - & 5 & - & $x$ & - & - \\
\hline Shovel Test 1 & - & 2 & - & - & - & - & - & - & - & - \\
\hline TOTAL & 83 & 196 & 21 & $207(2) *$ & 32 & 441 & - & - & 7 & 16 \\
\hline
\end{tabular}

*The figure in parentheses denotes the presence of aluminum foll fragments--the exact count of these fragments was not taken.

$X=$ presence of material 


\section{Earthenware}

The earthenware ceramics recovered from the site (Table 1I) include one sherd of blue feather-edged earthenware from a plate (Fig. 16,a). These featheredged, or shel1-edged, earthenwares could date to as early as 1795--they were made from 1780 to ca. 1830 (Fox, Bass, and Hester 1976:58; Nöel Hume 1970:131)--but in Texas they are general1y considered to date prior to 1850 (Ma1 1ouf, Fox, and Briggs 1973:170), which would be during the De Zavala family occupation of the Point. Other sherds dating to the same general period are four blue transfer plate sherds (Fig. 16,b), two sherds of a handpainted plate (Fig. $16, c)$, and three flow blue plate sherds (Fig. 16,d). Blue transfer earthenware probably dates from 1820 to 1830 , but it may date from 1795 up to the present. With the exception of one flow blue sherd from backhoe trench 5-1, a 11 these early earthenware sherds were collected from the general surface of the project area.

The 27 plain white sherds, which are from plates and cups (Fig. 16,e) and from the 1 id of a circular container, probably date from the post-Civil War period through the 1920s or 1930s. The container 1id has a black transfer 1 abel on it (Fig. 16,f). Four of these sherds were recovered from the shel1 midden deposits in backhoe trench 5-2, and one was from unit $N 40 / W 36$, level 3 .

The six sherds from a blue glazed bow 1 (Fig. 16,g) date to the post-1900s, and were recovered from the she11 midden deposits in backhoe trench 5-2, and in unit N48/W33, leve1s 1 and 2. Two sherds from a contemporary painted flowerpot, possibly from Mexico, were found in the dredged material.

\section{Stoneware}

Stoneware ceramics collected from 41 HR 39 (Table 12) include four sherds with an Albany slip, one sherd with a Rockingham glaze, and five sherds with a salt glaze, a11 of which date to the late 1800s. Also dating to the same period were five sherds which have an exterior salt glaze and an interior Albany slip. Al1 these early stoneware ceramics were collected from the surface of various areas of the site except one sherd from backhoe trench 5-2 that has a salt glaze and an Albany s1ip. One sherd from a striped yel $10 w$ ware bow 1 was also found on the site surface, and may date to the 1 ate 18005 or early 1900s (Raycraft and Raycraft 1975:P1ate 16).

Two sherds with a Bristol glaze, one sherd with a Bristol glaze and an Albany slip, and a blue glazed stoneware sherd date to post-1900. These ceramics are a 11 from surface collections.

The 1 arge basal sherd of a charcoal brazier found on the site surface may date from the 1800 s through the 1930s. One square of recent, brown ceramic tile, which probably dates to the 1920 s or 1 ater, was a 150 collected from the surface of the site.

The two sherds recovered from the surface with the blue sponged design (Fig. 16,h) may date to the turn of the century, although vessels of this sort were made well into this century (Raycraft and Raycraft 1975:P1ate 14). 
TABLE 11. PROVENIENCE OF HISTORIC CERAMICS: EARTHENWARE

\begin{tabular}{|c|c|c|c|c|c|c|c|}
\hline Provenience & $\begin{array}{l}\text { Plain } \\
\text { Whiteware }\end{array}$ & $\begin{array}{l}\text { Blue } \\
\text { Feathered } \\
\text { Edge }\end{array}$ & $\begin{array}{c}\text { Blue } \\
\text { Transfer }\end{array}$ & $\begin{array}{l}\text { Hand } \\
\text { Painted }\end{array}$ & $\begin{array}{l}\text { Flow } \\
\text { Blue }\end{array}$ & $\begin{array}{l}\text { Blue } \\
\text { Glazed }\end{array}$ & Flowerpot \\
\hline Surface &  & & & & & & \\
\hline Collection & 20 & 1 & 4 & 1 & 2 & - & - \\
\hline NW Quad. & $i$ & - & - & 1 & - & - & - \\
\hline $\begin{array}{l}\text { Dredged } \\
\text { Material }\end{array}$ & 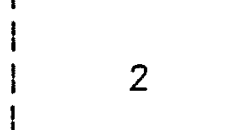 & - & - & - & - & - & 2 \\
\hline Trench 5-1 & $i$ & - & - & - & 1 & - & - \\
\hline Trench 5-2 &  & - & - & - & - & 3 & - \\
\hline $\begin{array}{l}\text { N40/W36 } \\
\text { Level } 2\end{array}$ & i & - & - & - & - & - & - \\
\hline$N 40 / W 36$ & $i$ & & & & & & \\
\hline Leve1 3 & i & - & - & - & - & - & - \\
\hline $\begin{array}{l}\text { N48/W33 } \\
\text { Level I }\end{array}$ & 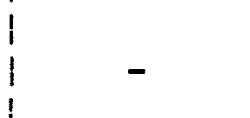 & - & - & - & - & 1 & - \\
\hline N48/W33 & 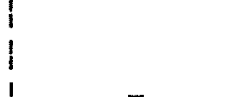 & & & & & & \\
\hline Level 2 &  & - & - & - & - & 2 & - \\
\hline TOTAL & 1 & 1 & 4 & 2 & 3 & 6 & 2 \\
\hline
\end{tabular}



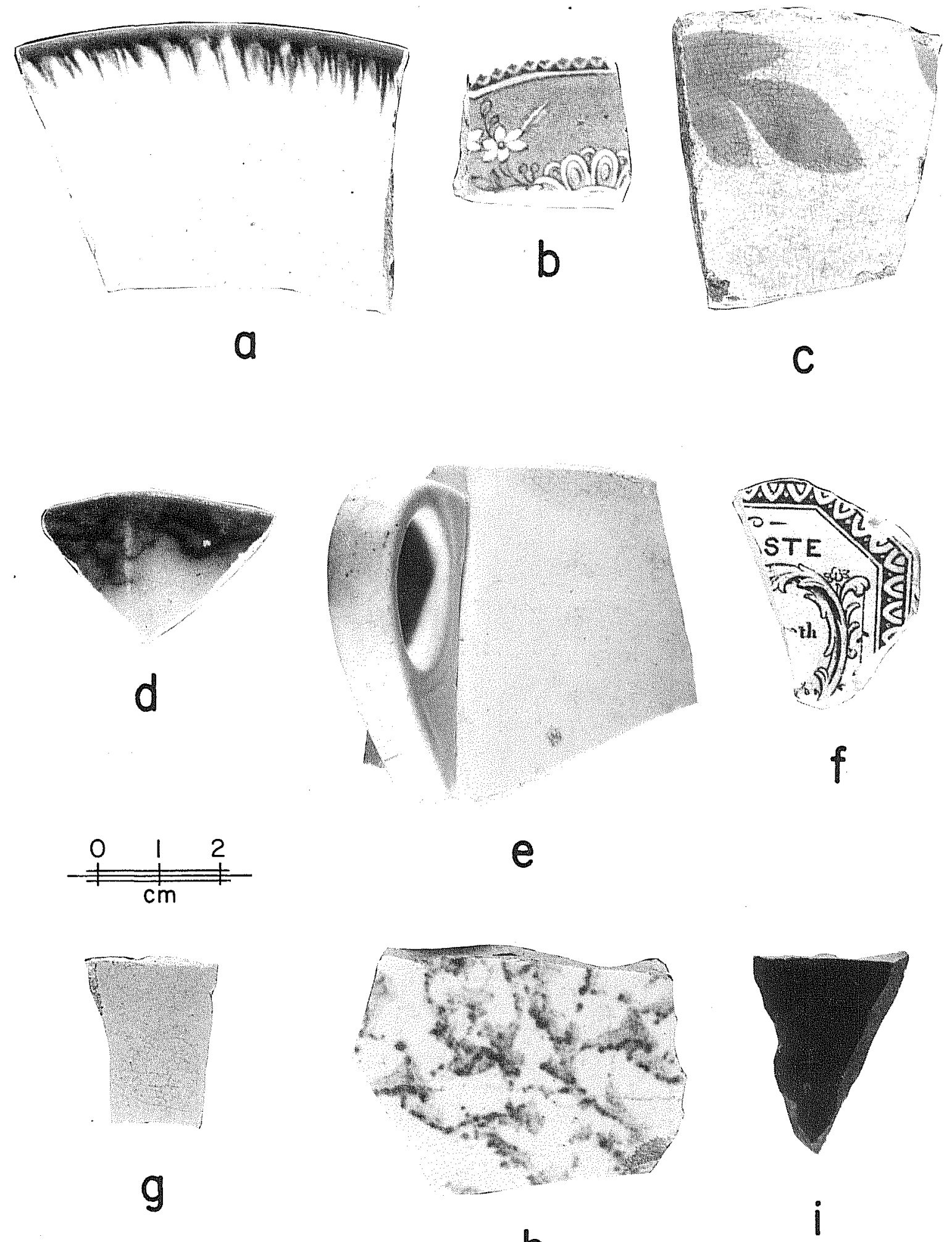

h

Figure 16. Historic Ceramics from Site 41 HR 39. a, blue feather-edged earthenware plate rim sherd; b, blue transfer earthenware plate rim sherd; $c$, hand-painted earthenware plate body sherd; d, flow blue earthenware plate rim sherd; e, plain white earthenware cup sherd with handle; $f$, plain white earthenware container 1 id sherd with a transfer 1 abe 1 ; g, blue glazed earthenware bow 1 sherd; $h$, blue sponged stoneware bow 1(?) sherd; i, redware bow 1 sherd. 
TABLE 12. PROVENIENCE OF HISTORIC CERAMICS: STONEWARE

\begin{tabular}{|c|c|c|c|c|c|c|c|c|c|c|c|c|}
\hline Proven fence & $\begin{array}{l}\text { Albany } \\
\text { slip }\end{array}$ & $\begin{array}{l}\text { Salt } \\
\text { Glaze }\end{array}$ & $\begin{array}{l}\text { Salt } \\
\text { Glaze/ } \\
\text { Albany } \\
\text { Slip }\end{array}$ & $\begin{array}{c}\text { Bristol } \\
\text { Glaze }\end{array}$ & $\begin{array}{l}\text { Bristol } \\
\text { Glaze/ } \\
\text { Albany } \\
\text { Slip }\end{array}$ & $\begin{array}{l}\text { Rockingham } \\
\text { Glaze }\end{array}$ & $\begin{array}{l}\text { Blue } \\
\text { Sponged }\end{array}$ & $\begin{array}{l}\text { B7ue } \\
\text { G1aze }\end{array}$ & Yellow Ware & Redware & $\begin{array}{l}\text { Charcoal } \\
\text { Brazier }\end{array}$ & Tile \\
\hline $\begin{array}{l}\text { Surface } \\
\text { Collection }\end{array}$ & 1 & 4 & 2 & 1 & - & 1 & 1 & 1 & 1 & 1 & 1 & 1 \\
\hline NW Quad & 1 & 1 & - & 1 & - & - & 1 & - & - & - & - & - \\
\hline Dredged Material & 2 & - & 2 & - & 1 & - & - & - & - & - & - & - \\
\hline Trench 5-1 & - & - & - & - & - & - & - & - & - & - & - & - \\
\hline Trench 5-2 & - & - & 1 & - & - & - & - & - & - & - & - & - \\
\hline $\begin{array}{l}\text { N40/W36 } \\
\text { Level } 2\end{array}$ & - & - & - & - & - & - & - & - & - & - & - & - \\
\hline $\begin{array}{l}\text { N40/W36 } \\
\text { Level } 3\end{array}$ & - & - & - & - & - & - & - & - & - & - & - & - \\
\hline $\begin{array}{l}\text { N48/W33 } \\
\text { Leve1 } 1\end{array}$ & - & - & - & - & - & - & - & - & - & - & - & - \\
\hline $\begin{array}{l}\text { N48/W33 } \\
\text { Level } 2\end{array}$ & - & - & - & - & - & - & - & - & - & - & - & - \\
\hline
\end{tabular}


The one sherd of redware (Fig. 16,i), found on the site surface, has a dark brown $\mathrm{glaze}$ and has not been assigned to any particutar period.

\section{Porcelain}

Seven plain white porcelain sherds were recovered from the site (Table 13). Five sherds were from the site surface, and two were from 1 evel 1 of unit N48/W33. Sherds of this sort, however, have been manufactured for a 1 ong period and therefore cannot be assigned to a particular period.

There were three pieces of contemporary blue and white porcelain tile collected. Two pieces of a recently made porcela in plumbing fixture were also found. These recent porcelain pieces were al1 from surface areas of the site.

\section{Glass}

The majority of the $196 \mathrm{~g} 1$ ass fragments collected from the project area (Table 14) were clear glass from recent soda bottles. Of the total of 123 clear glass fragments recovered, 101 were from the controlled excavation units. Clear glass fragments may date from 1880 or earlier to the present (Newman 1970:Fig. 3). One fragment collected from the site surface, however, was from a goblet, and may date to 1910-1920. Another fragment, al so from the site surface, was from the chimney rim of an oil or kerosene 1 amp; it probably dates prior to 1900. Five or more clear fragments which were melted from burning were from the general site surface and from backhoe trench 5-2. Nine clear glass fragments from window panes were recovered from backhoe trench 5-1, and from unit N40/W36, levels 2 and 3. One clear fragment from backhoe trench 5-1 was pressed glass and had a 1 ate 1800 s design on it (Fig. $17, a)$.

Eighteen fragments of brown glass were recovered; the majority were from unit N40/W36, leve1 3, and unit N48/W33, 1eve1s 1 and 2 . These fragments were from beer or whiskey bottles and may date from the $1880 \mathrm{~s}$ up to the present. An employee at the 01d River Fleet and Shipyard stated that many bottles and bottle fragments were found at the site, and thought that they dated to the 1920 s when a bootlegging operation was operating on De Zavala Point. The archaeologists did not see any of the reported bottles, however.

Four fragments of olive glass were found on the site surface and also in unit N48/W33, leve1 1, but they can on ly be dated to a wide time range. The two fragments of green glass from the shel 1 midden deposit in backhoe trench 5-1 are from contemporary botties.

The purple, or amethyst, coloring in the eight fragments of purple bottle glass is caused by manganese which was added during manufacture. One of the purple sherds was from backhoe trench 5-1, and three were from 1 evels 1 and 2 of unit N48/W33. One purple glass fragment from the surface collection was from the rim of an oil or kerosene $1 \mathrm{amp}$ chimney (Fig. 17,b), which would probably date prior to 1900. There was one fragment of purple pressed glass from the surface collection in the northwestern quadrant of the site. 
TABLE 13. PROVENIENCE OF HISTORIC CERAMICS: PORCELAIN

\begin{tabular}{|c|c|c|c|c|}
\hline Provenience & Undecorated & $\begin{array}{l}\text { Undecorated } \\
\text { with Transfer } \\
\text { Printed Label }\end{array}$ & Tile & $\begin{array}{l}\text { Plumbing } \\
\text { Fixture }\end{array}$ \\
\hline $\begin{array}{l}\text { Surface } \\
\text { Collection }\end{array}$ & 4 & 1 & 3 & 1 \\
\hline NW Quad & 1 & - & - & 1 \\
\hline Dredged Material & - & - & - & - \\
\hline Trench 5-1 & - & - & - & - \\
\hline Trench 5-2 & - & - & - & - \\
\hline $\begin{array}{l}\text { N40/W36 } \\
\text { Level } 2\end{array}$ & - & - & - & - \\
\hline $\begin{array}{l}\text { N40/W36 } \\
\text { Level } 3\end{array}$ & - & - & - & - \\
\hline $\begin{array}{l}\text { N48/W33 } \\
\text { Leve1 } 1\end{array}$ & 2 & - & - & - \\
\hline $\begin{array}{l}\text { N48/W33 } \\
\text { Leve1 } 2\end{array}$ & - & - & - & - \\
\hline
\end{tabular}



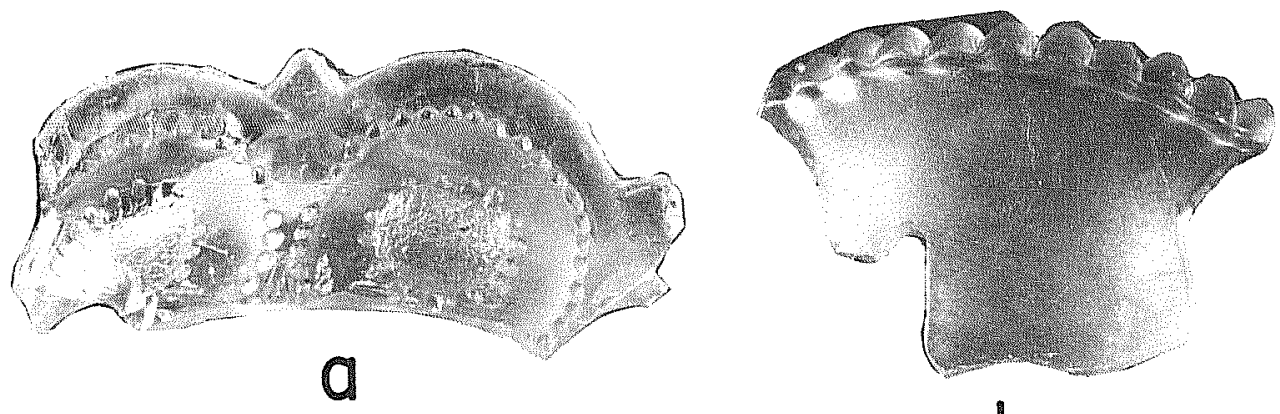

b
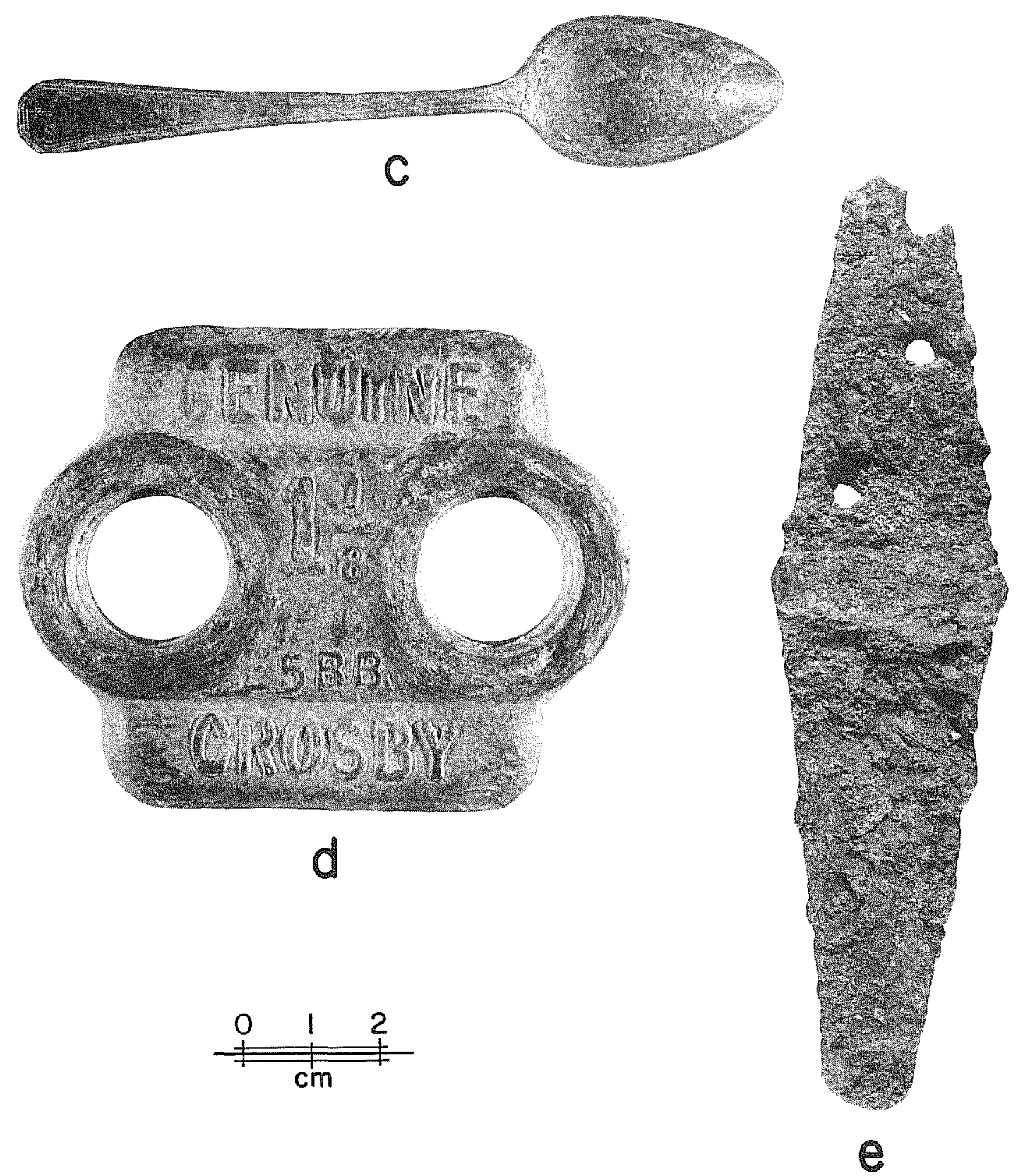

Figure 17. G1ass and Metal Artifacts from Site 41 HR 39. a, clear pressed glass vessel 1 id rim fragment; b, purple 1 amp chimney rim glass fragment; c, small child's(?) spoon; d, steel cable tie-down; e, iron hinge. 
TABLE 14. PROVENIENCE OF GLASS

\begin{tabular}{|c|c|c|c|c|c|c|c|c|c|c|c|}
\hline Provenience & $\begin{array}{l}\text { Clear } \\
\text { Glass }\end{array}$ & $\begin{array}{l}\text { Clear } \\
\text { Window } \\
\text { Glass }\end{array}$ & $\begin{array}{l}\text { Clear } \\
\text { Pressed } \\
\text { Glass }\end{array}$ & $\begin{array}{l}\text { Brown } \\
\text { G1 ass }\end{array}$ & $\begin{array}{l}\text { Olive } \\
\text { Glass }\end{array}$ & $\begin{array}{l}\text { Green } \\
\text { G1 ass }\end{array}$ & $\begin{array}{l}\text { Purple } \\
\text { G1ass }\end{array}$ & $\begin{array}{l}\text { Purple } \\
\text { Pressed } \\
\text { Glass }\end{array}$ & $\begin{array}{l}\text { Aqua } \\
\text { Glass }\end{array}$ & $\begin{array}{l}\text { Cobalt } \\
\text { G1ass }\end{array}$ & $\begin{array}{l}\text { Milk } \\
\text { G1ass }\end{array}$ \\
\hline $\begin{array}{l}\text { Surface } \\
\text { Collection }\end{array}$ & 14 & 1 & _- & 3 & 2 & - & 4 & - & 5 & 2 & 1 \\
\hline NW Quad & 1 & - & - & - & 1 & - & - & 1 & - & - & - \\
\hline Dredged Material & a - & - & - & - & - & - & - & - & - & - & - \\
\hline Trench 5-1 & 2 & 2 & 1 & 3 & - & 2 & 1 & - & 2 & - & - \\
\hline Trench 5-2 & 3 & - & - & - & - & - & - & - & 2 & - & - \\
\hline $\begin{array}{l}\text { N40/W36 } \\
\text { Level } 2\end{array}$ & 9 & 1 & - & - & - & - & - & - & - & - & - \\
\hline $\begin{array}{l}\text { N40/W36 } \\
\text { Level } 3\end{array}$ & 22 & 5 & - & 4 & - & - & - & - & 4 & - & - \\
\hline $\begin{array}{l}\text { N48/W33 } \\
\text { Level } 1\end{array}$ & 57 & - & - & 7 & 1 & - & 2 & - & 12 & - & - \\
\hline $\begin{array}{l}\text { N48/W33 } \\
\text { Leve1 } 2\end{array}$ & 13 & - & - & 1 & - & - & 1 & - & 2 & - & - \\
\hline $\begin{array}{l}\text { Shove1 } \\
\text { Test } 1\end{array}$ & 2 & - & - & - & - & - & - & - & - & - & - \\
\hline TOTAL & 123 & 9 & 1 & 18 & 4 & 2 & 8 & 1 & 27 & 2 & 1 \\
\hline
\end{tabular}


Pressed glass vessels of this color date from 1880 to 1925 (Newman $1970:$ Fig. 3). Voellinger (1982:12) reported finding a purple bottle stopper at site 41 HR 423, a southern extension of site 41 HR 39.

Of the 27 aqua glass fragments found, most are from contemporary bottles. Eighteen of these fragments are from unit N40/W36, level 3 and unit N48/W33, levels 1 and 2. Three bottle neck fragments from the surface collection are from a bottle manufactured at the turn of the century.

Two cobalt glass fragments from a cup were recovered from the site surface. They may date from the 7 ate 1800 s to the present.

The one milk glass fragment recovered could not be assigned to any particular period because of its long period of manufacture. It is from the surface collection.

\section{Metal}

The metal materials recovered from the site (Table 15) were predominantly badly corroded and appeared to be recent. A smal1 spoon which was formerly silver plated and possibly made for a child ( $F i g .17, C)$, was found on the surface of the northwest quadrant of the site. A steel cable tie-down from a ship, with the inscription "GENUINE, 1 1/8, E5BB, CROSBY" (Fig. 17,d), came from unit $N 40 / W 36$, leve1 2.

An iron square spike was collected from the site surface. An iron square nai1, which may date prior to 1890, came from unit N48/W33, level 1 . The 25 cut or wire nails, which occur in Texas around 1890 up to recent times, were from backhoe trenches 5-1 arid 5-2, levels 2 and 3 of unit N40/W36, and level 1 of unit N48/W33. A large iron bolt and washer was from backhoe trench 5-1. One galvanized roofing nail was found in level l of unit N48/W33.

An iron hinge (Fig. 17,e) was collected from backhoe trench 5-2. Fourteen pieces of iron wire were recovered from unit N40/W36, levels 2 and 3 and unit N48/W33, leve1 1. Four pieces of an iron can base were al so collected in unit N48/W33, Teve1 1. Rough 1 y 152 rusted iron fragments were col 1 ected, nine from backhoe trenches 5-1 and 5-2, and 143 from the excavation units, with the most coming from unit N48/W33, level 1. Voe11inger (1982:12) reported finding metal fragments at site 41 HR 423 , which is actual $1 y$ the southern end of site 41 HR 39. One piece of bronze al loy wire, pointed on the end, came from backhoe trench 5-1. A brass grommet came from unit N40/W36, leve1 3, and a brass ferrule came from unit N48/W33, Tevel 1.

A 1 ive .30-06 caliber Springfield round, which probably dates to the World War II military utilization of De Zavala Point, was excavated from level 2 of unit N48/W33 (the 1 ive round was disposed of). A.22-caliber cartridge which appears to be recent, came from unit N48/W33, level 1.

There were brittle fragments of aluminum foil found in backhoe trench 5-2 and in unit N48/W33, level 1. These pieces of foil continued to fragment after 
TABLE 15. PROVENIENCE OF METAL ARTIFACTS

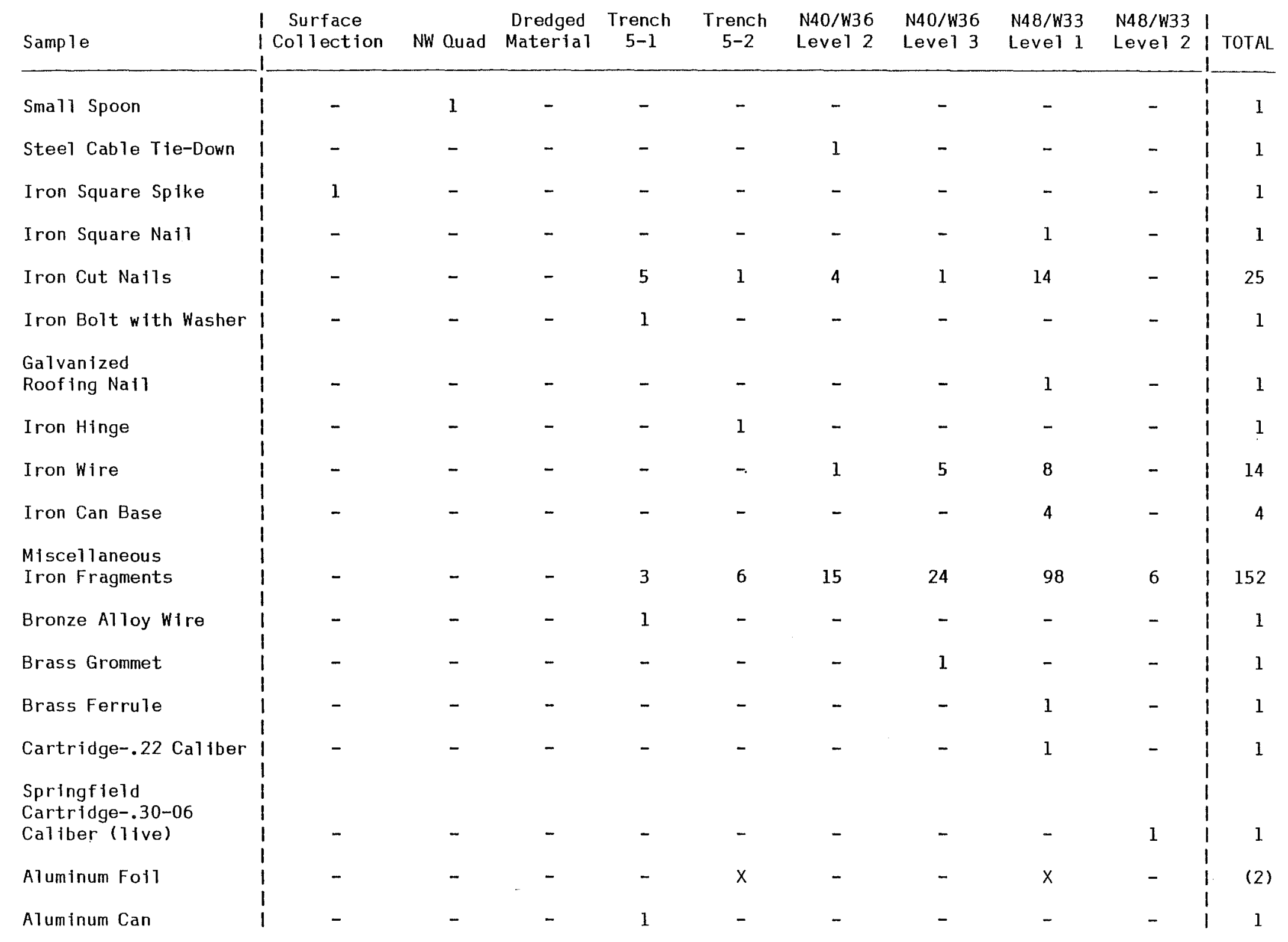


they were collected, so the presence or absence of the foil rather than a count is given in Table 15.

\section{Other Historic Materials}

Chert grave1s, including flakes which appear to have been processed through a rock crusher, were found on the surface of the site; these materials are discussed previously in the section on prehistoric 1 ithics (Table 3 ). Fragments of sandstone, found only on the surface of the site, showed no signs of alteration and could possibly have been brought into the area as historic contruction material. Pieces of concrete, coal, asphalt, and plaster were also collected. A fragment of a stone disc, made of an identified type of orthoquartzite and which was originally $21 \mathrm{~cm}$ in diameter and $1.9 \mathrm{~cm}$ thick, was found along the northern bluff exposure in the northwestern quadrant of the site. The function of the stone disc is unknown though it is speculated that it may have served as a crock cover.

Eroded fragments of handmade, chocolate-colored burned brick were found across the surface of the site, in backhoe trenches 5-1 and 5-2, level 3 of unit N40/W36, and level I of unit N48/W33 (Table 10). These pieces of brick may be from construction at the site, or may have been dumped there. It is also possible that they resulted from brick firing at De Zavala Point, discussed previously in the site description section of this report, though there are no records of this. Most probably, though, the brick was made at the Cedar Bayou brickyards and was transported to the site. Voel 1 inger (1982:12) reported finding an intact course of handmade bricks on the southern side of De Zavala Point. Cartier and Hole (1972:32) note that the brick used to construct numerous buildings, especially foundations and chimneys in San Jacinto, Texas, during the 1840s was obtained from the Cedar Bayou brickyards. These brickyards, which had up to $11 \mathrm{kilns}$, also supplied brick to Houston and Galveston from 1850 to 1900. Bricks produced at Cedar Bayou were recovered from the San Jacinto Battlefield (ibid.), and the burned, chocolate-brown brick fragments found at site 41 HR 39 also appear to have been produced there (Anne Fox, personal communication). The badly burned appearance of the brick may indicate that these pieces were "wasters," brick which was overfired in the kiln during manufacture (Anne Fox, personal communication). Handmade brick was produced at Cedar Bayou from ca. 1850 or 1865 through the early 1900s (Martin 1968). Burned clay was collected from the northwestern quadrant of the project area by the northern bluff of De Zavala Point (Table 10). It was also found in backhoe trench 5-1, an area which was obviously highly disturbed. The unweathered appearance of the burned clay suggests that it dates to the historic component at the site, rather than to the aboriginal occupation.

A mottled dark brown, mineral doorknob collected from the surface of the site probably dates to the turn of the century. Doorknobs of this type are described in the 1897 Sears Roebuck catalog (Israel 1968:90), and are the least expensive kind 1 isted.

Tiny, dull white to amber-colored polyethylene pellets, ranging from $3.5 \mathrm{~mm}$ to $1 \mathrm{~mm}$ in diameter, were found in the fill from the excavation units; only a smal1 amount of the pellets found were collected. These pel1ets, which 
common 7 y occur in beach drift, came from chemical plants located at Texas ports such as Houston (Andrews 1971:269). Smal1 fragments of styrofoam and sheet plastic were also recovered from the dredged material and from the excavation units.

\section{DISCUSSION}

Overal1, the presence of numerous historic materials within the shel1 midden deposit indicates that the historic materials were intermixed with the aboriginal cultural remains. The method by which these materials were combined is not certain, but the highly disturbed state of the site is evident. Almost all of the early historic materials were from surface collections at the site.

\section{SUMMARY AND RECOMMENDATIONS}

Personnel from the CAR-UTSA conducted archaeological investigations on De Zavala Point in Channelview, Harris County, Texas (Fig. I), for the Department of the Army, Galveston District, Corps of Engineers. The project involved test excavations at site 41 HR 39, a prehistoric she 11 midden with a historic component, to assess the eligibility of that site for the National Register of Historic Places.

Site $41 \mathrm{HR} 39$ is on the northwestern part of De Zavala Point, on top of a 6.1-m-high bluff overlooking the confluence of the $01 \mathrm{~d}$ River and Buffalo Bayou (Fig. 2). The shell midden deposits are visible along the northern and northeastern banks of the Point, and eroding she 11 and artifacts are visible on the surface in the southeastern part of the project area (Figs. 4-5).

The field work was intended principal1y to determine the extent, cultura 1 stratigraphy and features, chronology, and potential of the site for yielding additional significant information. To achieve these goals the project area was mapped; nine shovel tests (ST 1-9), two $1-\mathrm{m}^{2}$ controlled test units (N40/W36, N48/W33), five backhoe test pits (BHTP A-E), and five backhoe trenches (BHT 1-5) were excavated (cf. Fig. 3). Artifacts were collected from the site surface and from the shorelines of the project area. The excavations showed a high degree of disturbance of the shell midden deposit in the eastern (ST 1; BHTP D), southern (ST 1-3, 7, 8; BHTP B,C,E), and western areas (ST 4-6; BHTP A; BHT 1-3) of the project area (Figs. 6-10, Table 1). The best-preserved she11 midden deposits, represented by a $2 \mathrm{~cm}$ to $45 \mathrm{~cm}$ thick stratum of Rangia shel1s in a sandy clay loam matrix with faunal materials and prehistoric ceramics, occurred in the north-central part (units N40/W36, N48/W33; BHT 4, 5) of the project area. Historic materials, such as glass, ceramics, and metal, which were recovered from the prehistoric shel 1 midden deposits, and a portion of a former she11-topped road which intruded into the she $11 \mathrm{midden}$ deposits (Figs. 16-17, Tables 10-15), evidenced the effects of bioturbation and a 1 so the long term occupation and usage of De Zavala Point during the Historic period.

The 613 prehistoric sherds col1 ected from the surface and from control1ed excavations within the project area consist of 579 plain sandy paste sherds, 
11 incised sandy paste sherds, two red-filmed sandy paste sherds, five plain she 11-tempered sherds, one incised shel1-tempered sherd, and $15 \mathrm{p} l \mathrm{a}$ in grogtempered sherds. A total of 44 ithics recovered from surface collections and from controlled excavations includes seven secondary flakes, eight interior flakes, four thinning flakes, seven flake fragments, four pieces of shatter, six pieces which had been altered by a mechanical crusher, and also two unifacial scrapers, two thin biface fragments, a mano fragment, an Ensor point, a Perdiz point, and a Type A-l point. These ceramics and 7 ithics indicate that the shel1 midden deposits date to the Ceramic period (ca. A.D. 100-1810), and perhaps prior to this date as well. Other prehistoric materials excavated from the two controlled test units at the site include $27048.3 \mathrm{~g}$ of Rangia cuneata she11s, $90 \mathrm{~g}$ of predominantly Crassostrea virginica shel1s, and a small amount of vertebrate faunal remains. A shell growth stage analysis, or seasonality study, of a sample of the excavated Rangia cuneata shel1s indicates that the shell was gathered during late May. The vertebrate faunal remains recovered from the backhoe trenches and from the controlled excavation units are similar to the faunal materials from other prehistoric shel1 midden sites in Galveston and Harris Counties. The faunal remains recovered represent gar, croaker, turtle, al1igator, an unidentified bird, possibly dog, white-tailed deer, domestic cow, and also possibly buffa10. The types of fauna represented in the assemblage were obtained from a variety of habitats. The two pieces of worked bone recovered from the backhoe trench collection areas are an aw 7 and a possible bead blank.

Historic materials recovered from the surface of the project area and also from excavations in the she 11 midden deposits. consist of 83 sherds, $196 \mathrm{~g} 1$ ass fragments, 21 handmade brick fragments, 16 pieces of burned clay, 207 pieces of metal, 32 pieces of plastic, and 441 pieces of concrete, coal, and plaster. These historic materials date from the 1820 s or $1830 \mathrm{~s}$ through recent times, a time span which would include, and possibly predate, the occupation of De Zavala Point by the Lorenzo de Zavala family in 1835.

Based upon the data gathered during this project and presented in this report, site 41 HR 39 is judged to have a 1 ow research potential and to be not eligible for the National Register of Historic Places. The major factor upon which this assessment is based is the intermixture of prehistoric and historic materials throughout the she 11 midden deposits. It is doubtful, therefore, that additional archaeological investigations at the site would yield important data beyond that which is presented in this report. 
Alperin, L. M.

1983 Custodians of the Coast, History of the United States Army Engineers at Galveston. Report on file at the Department of the Army, Galveston District, Corps of Engineers. Galveston, Texas.

Andrews, J.

1971 Sea She11s of the Texas Coast. University of Texas Press, Austin.

Arbingast, S. A., L. G. Hennamer, R. H. Ryan, A. Lo, D. L. Karney, C. P. Zlatovich, M. E. Bonine, and R. G. Steele

1973 Atlas of Texas. Bureau of Business Research, The University of Texas at Austin.

Aronow, S.

1982 Letter to D. WiTliam Day, project archaeologist for Espey, Huston \& Associates, on the geomorphology of De Zavala Point. October 20, 1984. Lamar University, Beaumont, Texas.

1984 Geomorphological Survey of Sites 41 GV 16, 41 GV 15, and 41 GV 14. Manuscript submitted to the Department of the Army, Galveston District, Corps of Engineers.

Aten, L. E.

1967 Excavations at the Jamison Site (4ILB2), Liberty County, Texas. Houston Archeological Society, Report 1.

1979 Indians of the Upper Texas Coast: Ethnohistoric and Archeological Frameworks. Ph. D. dissertation, The University of Texas at Austin.

1981 Determining Seasonality of Rangia cuneata from Gulf Coast Shel1 Middens. Bulletin of the Texas Archeological Society $52: 179-200$.

1983a Indians of the Upper Texas Coast. Academic Press, New York.

1983b Analysis of Discrete Habitation Units in the Trinity River Delta, Upper Texas Coast. The University of Texas at Austin, Texas Archeological Research Laboratory, Occasional Papers 2. 
Bernard, H. A. and R. J. LeBlanc

1965 Resume of the Quaternary Geology of the Northwest Gulf of Mexico Province. In The Quaternary of the United States, edited by H. E. Wright, Jr. and D. G. Frey:137-185. Princeton University Press, New Jersey.

Bernard, H. A., C. F. Major, Jr., B. X. Parrot, and R. J. LeBlanc, Sr.

1970 Recent Sediments of Southeast Texas. Bureau of Economic Geology, The University of Texas at Austin, Guidebook 11.

Black, A.

1982 Personal communication (historic sites specialist), interview, with L. R. Voe 11 inger, Texas Parks and Wild 1 ife Department. Aprit 14. Austin, Texas.

Bolton, H. E.

1962 Texas in the Middle Eighteenth Century. Russe11 and Russe11, New York.

Brandimarte, $\mathrm{C}$.

1982 Archival Research for the Lorenzo De Zavala Homesite. Espey, Huston \& Associates, Job 1584. Austin, Texas.

Bureau of Economic Geology

1982 Geologic Atlas of Texas. Houston Sheet. Bureau of Economic Geology, The University of Texas at Austin.

Calhoun, C. A.

1961 Scored Pottery of the Texas Coastal Bend. Bulletin of the Texas Archeological Society 32:321:325.

Carlson, D. L.

1983 Rangia cuneata as a Seasonal Indicator for Coastal Archeological Sites in Texas. Paper presented at the 48 th Annual Meeting of the Society for American Archeology. Pittsburgh.

Carr, J. T., Jr.

1967 The Climate and Physiography of Texas. Texas Water Development Board, Report 53. 
Cartier, R. R. and F. Hole

1972 Part I: History of the McCormick League and Areas Adjoining the San Jacinto Battl eground. Report prepared by Arcon, Inc., in compliance with Permit No. 11 granted to Coastal Industrial Water Authority by the Antiquities Committee of the State of Texas.

Crabtree, D. E.

1972 An Introduction to the Technology of Stone Tools. Occasional Papers of the Museum, Idaho State University 28. Pocate 110.

Day, D. W.

1982 Cultural resources letter report on site testing at De Zavala Point. November 5. Espey, Huston \& Associates, Job 1584. Austin, Texas.

Department of the Army, Galveston District, Corps of Engineers

1984 Scope of Work: National Register Testing of Site 4IHR39, Harris County, Texas. Galveston, Texas.

De Zavala, A.

1934 In Grandmother's $01 d$ Garden Where the Rose Reigned as Queen. Unidentified newspaper clipping dated September 2. Lorenzo de Zavala Biographical File, The University of Texas at Austin.

Dillehay, T. D.

1975 Prehistoric Subsistence Exploitation in the Lower Trinity River Delta, Texas. Texas Archeological Survey, The University of Texas at Austin, Research Report 51.

Fenneman, N. M.

1938 Physiography of the Eastern United States. McGraw-Hi11, New York.

Fieids, R. C. and J. M. Jackson

1984 Archeological and Historical Investigations at 4 lGVI4 and 41GV15, Galveston County, Texas. Prewitt and Associates, Inc., Reports of Investigations 34. Austin, Texas.

Fisher, W. L., J. H. McGowen, L. F. Brown, Jr., and C. G. Groat

1972 Environmental Geologic Atlas of the Texas Coastal Zone: Galveston-Houston Area. Bureau of Economic Geology, University of Texas at Austin. 
Fossen, $V$.

1982 Personal communication, phone interview, with L. R. Voel1inger. Aprit 12. Houston, Texas.

Fox, A. A.

1982 The History of the Lorenzo de Zavala Cemetery and Assessment of Associated Archaeological Sites. Unpublished report prepared for TERA Corporation of Da11as, Texas.

Fox, A. A., F. A. Bass, Jr., and T. R. Hester

1976 The Archaeology and History of Alamo Plaza. Center for Archaeological Research, The University of Texas at San Antonio, Archaeological Survey Report 16.

Fulten, L.

1982 Personal communication, interview, with L. R. Voellinger. Apri1 7. Deer Park, Texas.

Gabryish, R. K. and C. W. Bonnet

1977 Land-Surface Subsidence in the Houston-Galveston Region, Texas. Texas Water Development Board, Report 188.

Gilbert, B. M.

1980 Mammalian 0steology. Modern Printing Company, Laramie, Wyoming.

Gilmore, K. K.

1974 Cultural Variation on the Texas Coast, Analysis of an Aboriginal She 11 Midden, Wal1 isville Reservoir, Texas. Texas Archeological Survey, The University of Texas at Austin, Research Report 44.

Harris County, Texas

Harris County Deed Records

Harris County Courthouse, Houston, Texas.

Houston Post

n.d. De Zavala Marker Pulled from Channel. Newspaper article in possession of Lewis Ful len of Deer Park, Texas. 
Israel, R. L., editor

19681897 Sears Roebuck Catalog. Chelsea House Publishers, New York.

Looscan, A.

1914 Harris County 1822-45. Texas State Historical Association, Austin, Texas.

Matlouf, R. J., D. E. Fox, and A. K. Briggs

1973 An Assessment of the Cultural Resources of Palmetto Bend Reservoir, Jackson County, Texas. Texas Historical Commission and Texas Water Development Board, Archeological Survey Report 11.

Martin, N. A.

1968 No Economic Problems on a Dollar per Day. February 16. In Appendix II: Brick-Making on Cedar Bayou, Part I: History of the McCormick League and Areas Adjoining the San Jacinto Battleground, by R. R. Cartier and F. Hole:61-78. Report prepared by Arcon, Inc., in compliance with Permit No. 11 granted to Coastal Industrial Water Authority by the Antiquities Committee of the State of Texas. This article originally appeared in the Baytown Sun, Baytown, Texas.

McGuff, P. R. and M. M. Ford

1974 Galveston Bay Area, Texas: A Study in Archeological and Historical Resources in Areas Under Investigation for Navigational Improvement. Texas Archeological Survey, The University of Texas at Austin, Research Report 36.

Mercado-Allinger, P. A., R. C. Fields, K. K. Gilmore, and N. Reese

1984 Inventory and Assessment of Cultural Resources, C1ear Lake Channel Improvement Project, Galveston and Harris Counties, Texas. Prewitt and Associates, Inc., Reports of Investigations 26. Austin. Texas.

\section{Munse11 Soil Color Charts}

1975 MacBeth Division of Kollmorgen Corporation, Baltimore, Maryland.

Newman, T. S.

1970 A Dating Key for Post-Eighteenth Century Bottles. Historical Archaeology $4: 70-75$. 
Nöel Hume, I.

1970 A Guide to Artifacts of Colonial America. Alfred A. Knopf, New York.

Poot, W. C.

1975 A Historical Atlas of Texas. Encino Press, Austin.

Raycraft, D. and C. Raycraft

1975 American Country Pottery. Wa 11 ace-Homestead Book Co., Des Moines, Iowa.

Scott, R. F. IV

1984 Faunal Identifications. Appendix D in Inventory and Assessment of Cultural Resources, Clear Lake Channel Improvement Project, Galveston and Harris Counties, Texas, by P. A. Mercado-Al 1 inger, R. C. Fields, K. K. Gilmore, and N. Reese. Prewitt and Associates, Inc., Reports of Investigations 26. Austin, Texas.

Shafer, H. J.

1973 Lithic Technology at the George C. Davis Site, Cherokee County, Texas. Ph.D. dissertation. Department of Anthropology, The University of Texas at Austin.

Shepard, A. 0 .

1963 Ceramics for the Archaeologist. Carnegie Institution of Washington, Publication 609. Washington, D.C.

Steere, A.

1982 Personal communication, interview, with L. R. Voellinger. Aprit 6. Channelview, Texas.

Stokes, J.

1984 Cultural Resource Survey Report of De Zavala Point for the Department of the Army Permit App 1 ication 17151. November 11. Galveston District, Corps of Engineers. Galveston, Texas.

Suhm, D. A. and E. B. Jelks

1962 Handbook of Texas Archeology: Type Descriptions. Texas Archeological Society, Special Publication 1, and Texas Memorial Museum, Bulletin 4. Austin, Texas. 
Suhm, D. A., A. D. Krieger, and E. B. Jelks

1954 An Introductory Handbook of Texas Archeology. Bu 11 etin of the Texas Archeological Society 25.

Sumpter, T.

1982 Personal communication, interview, with L. R. Voel1inger. Aprit 8. Channelview, Texas.

Turner, E. S. and T. R. Hester

1985 Stone Artifacts of Texas Indians. Texas Monthly Press, Austin.

United States Department of Agriculture (USDA)

1976 Soil Survey of Harris County, Texas. Harris County, Texas. Soi 1 Conservation Service, Washington, D.C.

Van Siclen, D. C. and R. W. Harlan (editors)

1965 The Deltaic Coastal Plain Guidebook. Houston Geological Society, Houston, Texas.

Voel1inger, L. R.

1982 A Search for the De Zavala Homesite and Other Cultural Resources, Harris County, Texas. Espey, Huston \& Associates, Job 1584. Austin, Texas.

Webb, W. P.

1952 The Handbook of Texas. Two volumes. Texas State Historical Association, Austin.

Wheat, J. B.

1953 The Addicks Dam Site: An Archeological Survey of the Addicks Dam Basin, Southeast Texas. River Basin Surveys Papers 4 , Part I, from Bureau of Ethnology Bul1etin 154:143-252. Government Printing Office, Washington, D.C.

Wheeler, F. F.

1976 Soil Survey of Harris County, Texas. United States Department of Agriculture, Soil Conservation Service, Washington, D. C.

Wil1 iams, E.

1982 Personal communication, interview, with L. R. Voel1inger. Aprit 6. Channelview, Texas. 